PATRICIA CAMPOS PAVAN BAPTISTA

\title{
INCAPACIDADE NO TRABALHO: A COMPREENSĀO DE GERENTES DE ENFERMAGEM
}


PATRICIA CAMPOS PAVAN BAPTISTA

\section{INCAPACIDADE NO TRABALHO: A COMPREENSĀO DE GERENTES DE ENFERMAGEM}

Tese apresentada à Escola de Enfermagem da Universidade de São Paulo para o concurso de Livre Docência, junto ao Departamento de Orientação Profissional.

São Paulo

2014 


\begin{abstract}
AUTORIZO A REPRODUÇÃO E DIVULGAÇÃO TOTAL OU PARCIAL DESTE TRABALHO, POR QUALQUER MEIO CONVENCIONAL OU ELETRÔNICO, PARA FINS DE ESTUDO E PESQUISA, DESDE QUE CITADA A FONTE.
\end{abstract}

Assinatura:

Data:

Catalogação na Publicação (CIP)

Biblioteca "Wanda de Aguiar Horta"

Escola de Enfermagem da Universidade de São Paulo

Baptista, Patricia Campos Pavan

Incapacidade no trabalho: a compreensão de gerentes de

enfermagem / Patricia Campos Pavan Baptista. -- São Paulo, 2014. $148 \mathrm{p}$.

Tese (Livre Docência) - Escola de Enfermagem da Universidade de São Paulo.

Departamento de Orientação Profissional

1. Recursos humanos - enfermagem. 2. Saúde ocupacional.

3. Serviços de saúde - administração. 4. Qualidade de vida. I. Título. 
Dedicatớria

Dedico esta pesquisa a todos os trabal hadores de enfermagem brasile ros, queaolongo desuas vidas, numprocesso dereciprocidade, ai dameadoecem emespecial, às gerentes deenfermagemquesedispuserama colaborar como estudo efizeram desse processo uma experiênđia encantadora no meu mundo vida. 


\section{Dedicatória Espedial}

Aomeu filhoFedipe, por tudo queéemminha vida... mau amor, mau amigo, mau companhero detodas as horas...Obrigada mau amor, por ter suportado esesmes de daboração da teœe mơtrando tão comprensivo esdidárioàmamãe TE AMO MAISDOQUE TUDO, VOOE É A MINHA VIDA! 


\section{Agradeaimentos}

A Deus, por meacal mar ocoração diantedas perdasemeiluminar a cada dia para a construção dediasmdhoresemaisfelizes

A minha mãe, uma mulher linda, generosa, tão dedicada em proteger-nos detudo;

A minha querida avó, por tudo quesau haje,

Ao Antonio Qival, por ter meajudado a enfrentar a perda, por ter medado a mãoe por meensinar todosos diasa adreditar na vida, nosmaussonhoseno futuro,

Ao Departamento de Orientação Profissional quemeacol heu como docenteet emme possibilitado no conviver diário, momentos de aprendizado, amizade e muitas alegrias,

A Admiráved Professora Vanda Elisa Andres Felli, que se transformou na minha querida amiga, parceira nos estudos de Saúde do Trabalhador de Enfermagem, parceira na vida, equeagora está mefazendo chorar detanta saudade,

A Professora Miriam Merighi, que meco-orientau no doutorado, por me despertar para a fenomend ogia e por ter meencorajado a real ização desta tese, me of erecendo carinhoe(comosempre) mito material bibliográfic;

A Professora ArleteSIlva, por ter permitido minha entrada naEEUSP, combal una demestrado, doutorado epor ser uma pessoa tão espedial naminha vida;

A Helôea Fê, chefeevice-chefe do Departamento deOrientação Profissional, por possibilitaremnovos desafios, 
A Daisy querida, por existir aqui na esola, por acolher, por ensinar, por inspirar a todasnós

Ao Oani, Andrẻa, Edina, por torcerem por mim.. e por tornarem tudo mais levee alegreno meu cotidiano detrabal ho.

As espedial istas eao Ricardo Góes... plo apaio diário nos al mọos enos corredores

A Lilian, umanjinho do oriente que caiu aqui no ENO e meajudau na fase final dessa empreitada

Aos amigos Paulinho, Cáudia, Duda, Adri e Simões...pdo œolo, pło aconchego e pelasinœra amizade

Ao meu grupo de pesquisa quememotiva a investir na construção do conhedimento em Saúde do Trabal hador, espeeialmente minhas orientandas por etarem sempre prontaspara colaborar.

A querida SIImer, por compartilhar comigo a fenomend ogia e exercitar a soliditude no nosso cotidiano.

A todos que estão no mau mundo vida e que de alguma forma, a partir da intendionalidade, ajudaram-mea concretizar esse projeto. 
Reoriatua vida, sempre, sempre Removepedrase planta rosiras efaz doces Recomesca.

Cora Coralina 
Hámomentos navida emquesentimostantoafalta dealquémqueoquemais

queremosétirar esta pessca denossos sonhos eabraçála

Sonhecomaquiloquevocêquiঞr. Seja oquevocêquer $₫$, porquevocêpossui apenas uma vida enda só setemuma dhancedefazer aquilo queseque. Tenhafelididade bastantepara fazêla doce Difiauldades parafazêla forte Tristeza para fazêla humana. E esperançasuficienteparafazêlafeliz. As pesscasmaisfelizesnão têmasmdhorescisas Elassabemfazer omdhor das oportunidadesqueapareœmemseuscaminhos A felididadeaparecepara aquelesquedhoram Para aquelesquesemaducam Para aquelesquebuscametentamsompre $E$ paraaquelesquereconhecema importânda daspessoasque passampor suas vidas.

Ofuturo maisbrilhanteébasado numpassado intensamentevivido. Vœêsót erá sucessona vida quando perdoer os erros eas decepçães do passado. A vidaécurta, mas as emoçãesquepodemos deixar duramuma eternidade A vidanãoédesebrincar porqueumbelodiasmorre GariœLispedor

Para voê, meu Dju (In Memoriam)...comtoda minha saudade.. 


\section{INCAPACIDADE NO TRABALHO: A COMPREENSĀO DE GERENTES DE ENFERMAGEM}

Introdução: No cenário nacional, as más condições de trabalho vivenciadas pelos trabalhadores de enfermagem caracterizadas pela inadequação de recursos materiais, físicos e humanos em aspectos quantitativos e qualitativos têm favorecido inúmeros processos de desgastes, os quais comprometem a capacidade laboral da força de trabalho em enfermagem, temporária ou permanentemente. Objetivo: compreender a ação de gerenciar a força de trabalho em enfermagem incapacitada. Método: Trata-se de uma pesquisa qualitativa fenomenológica realizada com 9 gerentes de enfermagem de hospitais públicos universitários brasileiros, das regiões norte, nordeste, centro-este, sul e sudeste. As entrevistas foram individuais, gravadas e os discursos foram transcritos e analisados segundo o referencial da fenomenologia social de Alfred Schütz. Resultados: A partir da análise do estudo foi possível identificar duas categorias concretas do vivido: $\boldsymbol{A}$ experiência de gerenciar a força de trabalho incapacitada e $A$ expectativa para a gestão de pessoas. A primeira categoria elucida o reconhecimento do contexto de adoecimento dos trabalhadores de enfermagem por parte das gerentes de enfermagem, a angústia que elas vivenciam para garantir a segurança do paciente e preservar a saúde dos trabalhadores de enfermagem, o prazer no trabalho gerencial e a organização do trabalho no contexto das incapacidades laborais. A segunda categoria evidencia os projetos de ação das gerentes de enfermagem, incluindo a construção de uma gestão mais participativa, o investimento em recursos humanos e ainda, o delineamento de novos caminhos. Considerações Finais: O presente estudo possibilitou a compreensão da ação de gerenciar a força de trabalho em enfermagem incapacitada sob a ótica de gerentes de enfermagem do cenário brasileiro, evidenciando a experiência de gerentes, marcada não somente pela angústia e pelas dificuldades na organização do trabalho mas, pela expectativa de transformações num contexto tão preocupante da assistência à saúde brasileira.

Descritores: Recursos Humanos de Enfermagem, Saúde do Trabalhador, Administração dos Serviços de Saúde; Qualidade de Vida. 


\section{WORK DISABILITY: THE UNDERSTANDING OF NURSING MANAGERS}

Introduction: On the national scene, the poor working conditions experienced by nursing professionals, which is characterized by the inadequacy of material, physical and human resources in quantitative and qualitative terms, have contributed to numerous processes of wear and tear, which compromise the labor ability of the nursing workforce, temporarily or permanently. Objective: aimed at understanding the action of managing the incapacitated nursing workforce. Methods: It is a present qualitative study with a phenomenological approach which was carried out with nine nursing managers of Brazilian public university hospitals from Northern, Northeastern, Midwestern, Southern and Southeastern regions. The interviews were individual, recorded and the statements were transcribed and analyzed according to the framework of the social phenomenology of Alfred Schütz. Results: From the analysis of the study, two concrete categories of the lived experience could be identified: The experience of managing the incapacitated workforce and The expectations for the personnel management. The first category elucidates the recognition of the context of the nursing workers' illness by nursing managers, the distress they experience to ensure patients' safety and to preserve the nursing staff's health, the pleasure in managerial work, and the work organization in the context of labor incapacities. The second category demonstrates nursing managers' action projects, including the construction of a more participatory management, investment in human resources and even the outline of new ways. Conclusions: The present study enabled the understanding of the action of managing the incapacitated nursing workforce from the perspective of nursing managers in the Brazilian scene, highlighting managers' experience, marked not only by the anguish and difficulties in work organization but also by the expectation for transformations in such worrying context of the assistance to Brazilian health.

Keywords: Nursing Human Resources, Worker's Health, Health Services Administration, Quality of Life. 


\section{SUMÁRIO}

Apresentação

1 Introdução .......................................................................... 18

2 Revisitando conceitos acerca da incapacidade para o trabalho em trabalhadores de enfermagem .................................................... 24

3 Referencial filosófico de Alfred Schütz e o contexto do estudo ............... 37

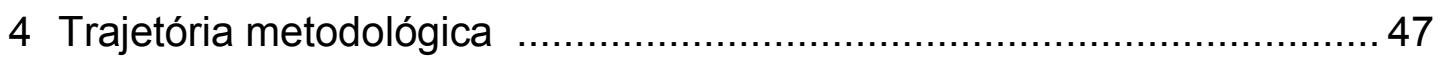

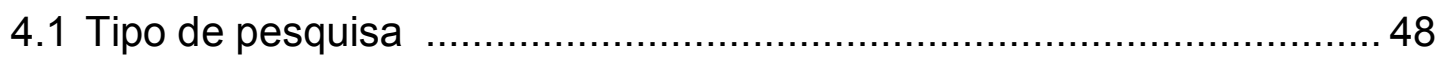

4.2 Região de inquérito e cenário da pesquisa .................................... 48

4.3 Sujeitos da pesquisa .............................................................. 49

4.4 Procedimentos para coleta de dados .......................................... 50

$4.5 \mathrm{O}$ caminho para análise dos discursos ....................................... 51

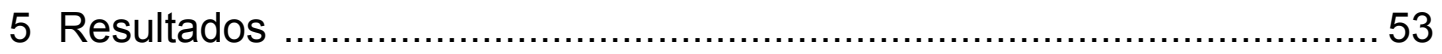

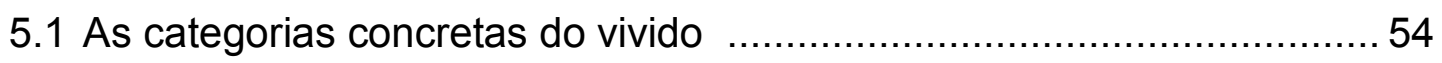

5.1.1 A experiência de gerenciar a força de trabalho incapacitada .............55

5.1.1.1 O reconhecimento do contexto de adoecimento e incapacidade dos trabalhadores de enfermagem ......................................... 55

5.1.1.2 A angústia para garantir a segurança do paciente e preservar a saúde dos trabalhadores de enfermagem ..................................62

5.1.1.3 O prazer no processo de trabalho gerencial ............................... 72

5.1.1.4 A organização do trabalho no contexto das incapacidades para

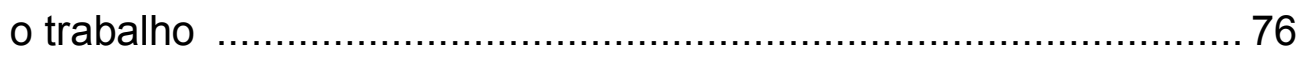

5.1.2 A expectativa para a gestão de pessoas .................................... 82

5.1.2.1 Construção de uma gestão mais participativa .............................. 82

5.1.2.2 Investimento em políticas de recursos humanos em saúde ............87 87

5.1.2.3 Delineamento de novos caminhos .......................................... 88

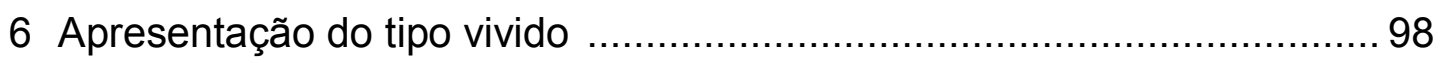

7 Discussão dos resultados ....................................................... 101

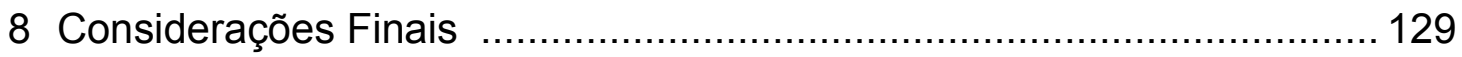

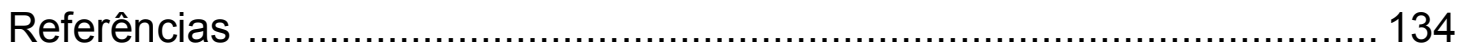

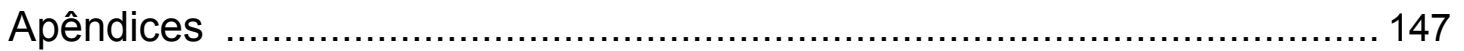


APRESENTAÇÃO 
O estudo da saúde dos trabalhadores de enfermagem tem permeado minha trajetória acadêmica, na qual evidencia-se por meio das diferentes pesquisas realizadas, os agravos ocorridos com os trabalhadores de enfermagem, caracterizados pelo expressivo número de problemas músculo-esqueléticos e adoecimento psíquico.

Nesse sentido, a realização de estudo anterior envolvendo os trabalhadores de enfermagem na elaboração e avaliação de propostas de intervenção com vistas à melhoria das condições de trabalho, apontou para a necessidade de envolver outros níveis hierárquicos para a efetivação de melhores condições de trabalho.

Assim, ao debruçar-me sobre as questões do adoecimento nos trabalhadores de enfermagem vislumbrando o delinear de novos caminhos, elaborei este estudo que pretende compreender o processo de adoecimento e incapacidade no trabalho sob a ótica de gerentes de enfermagem de hospitais públicos e universitários brasileiros, considerando que as transformações no ambiente laboral perpassam por uma construção coletiva de todos os sujeitos envolvidos no processo de trabalho.

Propor esta pesquisa, envolvendo os gerentes de enfermagem no âmbito nacional, torna-se fundamental na medida que o adoecimento e a incapacidade no trabalho se constituem uma realidade preocupante nos trabalhadores de enfermagem brasileiros e o engajamento de líderes é preditor para o sucesso dos Programas de Retorno ao Trabalho.

A apresentação formal do texto está construída em oito capítulos:

No capítulo 1, apresento a problemática que me conduziu à realização da pesquisa e as minhas inquietaçōes, enquanto pesquisadora acerca do fenômeno a ação de gerenciar a força de trabalho em enfermagem incapacitada sob a ótica de gerentes de enfermagem; 
No capítulo 2, realizo uma breve revisão dos conceitos acerca do adoecimento e da incapacidade para o trabalho nos trabalhadores de enfermagem;

No capítulo 3, apresento o referencial da fenomenologia social de Alfred Schütz articulado ao contexto do estudo;

No capítulo 4, descrevo a trajetória metodológica que possibilitou a elaboração da pesquisa;

No capítulo 5, apresento a organização e análise de categorias concretas, a partir dos trechos extraídos dos discursos das gerentes de enfermagem;

No capítulo 6, apresento o tipo vivido, que descreve a vivência das enfermeiras gerentes no contexto da incapacidade laboral dos trabalhadores de Enfermagem (motivos porque) e a intencionalidade das açōes dos gestores para essa problemática (motivos para), conforme o referencial de Alfred Schütz;

No capítulo 7, discuto as categorias concretas a partir do referencial filosófico e da literatura pertinente e atualizada ao objeto de estudo;

No capítulo 8, elucido algumas considerações e implicações dos resultados para a prática de enfermagem. 
1. Introdução 
A aposentadoria precoce por invalidez é um problema de saúde pública e o ambiente de trabalho é reconhecidamente relacionado ao encurtamento das carreiras profissionais, onde os principais fatores de risco são o trabalho físico e o baixo controle do processo de trabalho por parte dos trabalhadores (Lahelma et al., 2012).

A incapacidade da força de trabalho em enfermagem tem sido abordada em vários estudos nacionais e internacionais (Souza, Santana, 2012; Silva, 2011; Mueller et al., 2010; Mininel, 2010; Leite, Merighi, Silva, 2007; Gurgueira, Alexandre, 2006), evidenciando uma problemática para os serviços de saúde, uma vez que impacta no gerenciamento de recursos humanos e na qualidade da assistência de enfermagem.

No cenário nacional, as más condições de trabalho vivenciadas pelos trabalhadores de enfermagem são exemplificadas pela inadequação de recursos materiais, físicos e humanos em aspectos quantitativos e qualitativos, podendo ocasionar não apenas o acidente de trabalho como uma diversidade de processos de desgastes, os quais comprometem a capacidade laboral destes trabalhadores, temporária ou permanentemente.

Ao longo da última década, vários estudos apresentam dados alarmantes sobre os acidentes e as doenças relacionadas ao trabalho em trabalhadores de enfermagem. Os acidentes com fluidos biológicos, a ocorrência de distúrbios musculoesqueléticos, as torções, as quedas e o sofrimento psíquico têm sido descritos como responsáveis pelo elevado absenteísmo, presenteísmo e inúmeras incapacidades (Santana et al., 2013; Farias et al., 2011; Griep et al., 2011; Mininel, Baptista, Felli, 2011; Pinheiro, Zeitoune, 2009; Sancinetti et al., 2009; Chiodi, Marziale, Robazzi, 2007; Leite, Silva, Merighi, 2007; Gurgueira, Alexandre, 2006).

Dentre as principais causas de incapacidade nos trabalhadores de enfermagem, destacam-se especificamente, as tendinites, as tenossinovites, a bursite, a síndrome do túnel do carpo e a lesão de Quervain, associados à 
depressão e os transtornos de ansiedade (Carugno et al, 2012; Ratier, 2012; Silva, 2012, Mininel, Baptista, Felli, 2011; Leite, Merighi, Silva, 2007).

Estudo internacional acerca da aposentadoria por invalidez evidenciou que dentre as condições de trabalho, as exposições ao esforço físico são as que mais ocasionam problemas músculo esqueléticos, enquanto que as exposições psicossociais são as principais causas de incapacidade mental (Lahelma et al., 2012).

Sendo assim, no cotidiano de trabalho de enfermagem observa-se com frequência a utilização de força física na manipulação de peso, adoção de posturas inadequadas para a movimentação de pacientes e equipamentos, além das demandas emocionais, inerentes ao cuidado, como o sofrimento e as perdas. Esse contexto diário de trabalho favorece o adoecimento e consequentemente a incapacidade de seus profissionais.

Tratando-se do adoecimento e da incapacidade no trabalho, frequentemente, a peregrinação do trabalhador lesionado, em busca de tratamento e reabilitação, decorrente da fragilidade dos Programas de Retorno ao Trabalho, remete-o às mesmas condições que geraram a lesão, evidenciando assim elevados índices de presenteísmo, caracterizado por uma diversidade de restrições (Silva, Baptista, 2013; Mininel, 2010).

A partir do estudo realizado pelo grupo de pesquisa que atuo como líder, junto a outra pesquisadora, identificamos os agravos ocorridos com os trabalhadores de enfermagem nos diferentes cenários do País, no período de um ano, por meio do Sistema Monitoramento da Saúde do Trabalhador de Enfermagem (SIMOSTE). Do total de 936 notificações no SIMOSTE, os desgastes predominantes referem-se às doenças do sistema osteomuscular com uma ocorrência de 229 registros (24,5\%), seguidos de causas externas como traumas, luxações e torções com 161 registros $(17,2 \%)$, das doenças do aparelho respiratório com 89 notificações $(9,5 \%)$ e 
dos transtornos mentais e comportamentais com 84 ocorrências $(9,0 \%)$ (Felli, Baptista, 2010).

O estudo evidenciou ainda que, os afastamentos do trabalho representam um total de 8.555 dias perdidos no conjunto dos cenários, sendo que o maior número de dias perdidos deveu-se aos transtornos mentais e comportamentais com 2.699 dias (31,5\%), seguido das doenças osteomusculares com 1.625 dias $(19,0 \%)$ e dos traumas com 1280 dias perdidos (15\%) (Felli, Baptista, 2010).

$\mathrm{Na}$ verdade, o cenário atual aponta para a necessidade de uma política nacional coerente, com diretrizes, estratégias, metas, além de uma equipe multiprofissional capacitada que integre as diferentes esferas de poder, com foco, inclusive, na prevenção efetiva dos agravos causados pelo ambiente de trabalho (Mininel, 2010).

Nesse sentido, enquanto enfermeira e docente de enfermagem, venho estudando a Saúde do Trabalhador de Enfermagem e por meio das pesquisas recentemente realizadas, verifico uma lacuna no conhecimento sobre estudos que abordem os dilemas e as dificuldades enfrentados por gestores de enfermagem diante da incapacidade da força de trabalho.

Em um estudo anterior, subsidiado pela Fundação de Amparo à Pesquisa do Estado de São Paulo (FAPESP), realizei a escuta aos trabalhadores acerca das estratégias de intervenção para a melhoria das condições de trabalho, onde pude constatar uma série de questões importantes para uma verdadeira transformação dos ambientes laborais, sendo uma delas, a participação dos supervisores, diretores e outros níveis de decisão para a construção de políticas institucionais direcionadas à saúde dos trabalhadores (Baptista, 2012).

Corroborando com esses dados, pesquisadores ressaltam a importância da participação de gerentes no processo de retorno ao trabalho, 
a fim de, minimizar o desgaste do trabalhador que se ausentou por incapacidade e favorecer sua reinserção de forma salutar. Acrescentam ainda que, uma das barreiras mais importante nos programas de retorno ao trabalho é a falta de integração com as atividades de gestão, pois a integração dos programas possibilita maior compromisso dos gestores com sua execução bem-sucedida, sendo esses aspectos essenciais para transpor os demais obstáculos (Silva, 2012; Lambeek et al., 2009; Reinhardt, Fischer, 2009).

A experiência brasileira de integração e multidisciplinariedade nos programas de retorno ao trabalho ainda é tímida, tendo em vista que, o modelo biomédico é a definição que embasa as políticas públicas da saúde do trabalhador. Sob este enfoque observa-se que a valorização do discurso médico em detrimento das variáveis sociológicas da incapacidade dificulta a execução de um programa de reabilitação que atenda às reais necessidades dos trabalhadores (Mininel, 2010; Takahashi et al., 2010; Diniz, Squinca, Medeiros, 2007).

Considerando o aumento expressivo das restrições dos trabalhadores de enfermagem, configurando variadas incapacidades, associado às lacunas nos programas de retorno ao trabalho em cenário nacional, a presente pesquisa tem como objeto de estudo a ação de gerenciar a força de trabalho em enfermagem incapacitada sob a ótica de gerentes de enfermagem.

A partir da problemática descrita, apresento as seguintes inquietações:

Qual a percepção dos gerentes sobre o adoecimento dos trabalhadores de enfermagem?

De que maneira os gerentes percebem a incapacidade dos trabalhadores de enfermagem? 
Quais as dificuldades enfrentadas pelos gerentes para assegurar a qualidade da assistência de enfermagem?

Quais as estratégias empregadas pelos gerentes para gerenciar os trabalhadores incapacitados?

Quais as expectativas dos gerentes acerca da problemática da incapacidade dos trabalhadores de enfermagem?

Desse modo, o objetivo do estudo é compreender a ação de gerenciar a força de trabalho em enfermagem incapacitada sob a ótica de gerentes de enfermagem no cenário brasileiro, considerando que ao desvelar esta experiência seja possível apreender as dificuldades, e os dilemas enfrentados pelos gerentes, em decorrência da incapacidade dos trabalhadores de enfermagem, tornando possível um repensar a construção de políticas institucionais e políticas públicas direcionadas à saúde dos trabalhadores, que possam transformar o atual cenário de adoecimento e incapacidade da força de trabalho da enfermagem brasileira.

Justifica-se ainda, na medida que vislumbra o reconhecimento de estratégias que viabilizem a construção e operacionalização de programas de retorno ao trabalho, que possam minimizar os prejuízos não apenas nos serviços de saúde, como para o trabalhador que adoece e evolui para uma incapacidade temporária ou permanente. 
2. Revisitando Conceitos Acerca da Incapacidade para o Trabalho em Trabalhadores de Enfermagem 
A literatura nacional e internacional evidencia que a incapacidade para o trabalho, decorrente de agravos relacionados à saúde é um problema em todo o mundo, com considerável custo socioeconômico e prejuízo psicossocial. Na maioria dos países, o ônus financeiro recai principalmente sobre os empregadores e para o sistema de segurança social, mas é importante destacar os prejuízos incalculáveis aos trabalhadores pelo adoecimento, pela perda de confiança e autoestima (Coggon et al, 2013; Mininel et al., 2012; Silva, 2012; Souza, Santana, 2012).

Essa realidade incide também nos serviços de saúde, uma vez que o avanço tecnológico e a busca pela excelência na qualidade assistencial, aliados ao incremento da produtividade e redução de custos são fatores importantes que têm influenciado de forma assinalável o perfil de morbidade dos seus trabalhadores.

Nesse contexto, observa-se 0 aumento da prevalência de acidentes e doenças relacionadas ao trabalho, como os Distúrbios Osteomusculares Relacionados ao Trabalho (DORT) e o surgimento de novas formas de adoecimento, como o estresse e sofrimento mental, tornando-se relevante a compreensão da organização do trabalho em saúde para um repensar políticas de intervenção direcionadas à sua força de trabalho (Mininel, Baptista, Felli, 2011; Toldrá et al., 2010; Giomo et al., 2009).

Diversos estudos nacionais e internacionais também alertam para as más condições de trabalho e adoecimento nos trabalhadores de enfermagem, onde a redução da força de trabalho, a precarização e o ritmo intenso têm sido fatores relevantes na gênese das incapacidades, sejam elas temporárias ou permanentes (Coogon, et al, 2013; Santana et al., 2013; Mininel et al., 2012; Baptista, Merighi, Silva, 2011; Consonni, et al, 2011).

Em relação à incapacidade dos trabalhadores de enfermagem, pesquisadores brasileiros vêm descrevendo a gravidade das restrições físicas e/ ou psíquicas, destacando que embora as restrições para o trabalho 
sejam prescritas com o intuito de afastar o trabalhador da exposição à determinada atividade e agravamento da sua doença, elas têm acarretado uma complexa situação para o funcionamento dos serviços de saúde, principalmente se houver uma redução significativa de recursos humanos (Silva, 2012; Gurgueira, Alexandre, 2006).

Nos serviços de saúde, as incapacidades para o trabalho tendem a ocasionar um ciclo preocupante de adoecimento nos trabalhadores de enfermagem, tendo em vista a penosidade do trabalho, as demandas psíquicas presentes especialmente nas atividades assistenciais, e a constante dificuldade de reposição da força de trabalho em termos quantitativos e qualitativos.

No Brasil, a Previdência Social classifica as incapacidades como temporárias e permanentes. As incapacidades temporárias compreendem os segurados que ficaram temporariamente incapacitados para o exercício de sua atividade laborativa em função de acidente ou doenças do trabalho. As incapacidades permanentes referem-se aos segurados que ficaram permanentemente incapacitados para o exercício laboral, no entanto, estas podem ser subdivididas em dois tipos: parcial e total. A incapacidade permanente parcial caracteriza-se pelo trabalhador acidentado em exercício laboral, após o devido tratamento clinico, apresentar sequela definitiva que implique em redução da capacidade. $\square \square$ a incapacidade permanente total ocorre quando o acidentado em exercício laboral apresentar incapacidade permanente e total para o exercício de qualquer atividade laborativa (Brasil, 2010).

Essa classificação de incapacidade segundo a legislação previdenciária brasileira $\square$ baseada somente na incapacidade física, entretanto, outros critérios devem ser empregados para uma avaliação mais adequada da incapacidade e possíveis estratégias para a reinserção do trabalhador na atividade laboral. 
Dessa forma, a fim de minimizar a subnotificação dos acidentes e das doenças do trabalho, o INSS instituiu, desde 2007, uma nova sistemática de concessão de benefícios acidentários, fundamentado em estudos estatísticos e epidemiológicos, mediante o cruzamento dos dados de código da Classificação Internacional de Doenças - CID 10 e de código da Classificação Nacional de Atividade Econômica - CNAE. Estes dados subsidiaram a construção de um instrumento auxiliar na análise e conclusão acerca da incapacidade laborativa pela perícia médica do INSS - o Nexo Técnico Epidemiológico Previdenciário (NTEP) (Brasil, 2010).

A indicação de NTEP está embasada em estudos científicos alinhados com os fundamentos da estatística e epidemiologia e a partir dessa referência, a medicina pericial do INSS ganhou uma importante ferramenta em suas análises para conclusão sobre a natureza da incapacidade no trabalho, uma vez que indica as possíveis relações entre atividade laboral desenvolvida e o agravo motivador da incapacidade (Brasil, 2010).

Além disso, a partir de abril de 2007, a caracterização de um benef cio como de natureza acident $\square$ ria desvincula-se da obrigatoriedade da existência de uma comunicação do evento pelo empregador, acarretando o reconhecimento e contabilização de eventos que não seriam informados pelos empregadores. Com esta mudança, em apenas 3 anos (entre 2007 e 2009) foram reconhecidos 541.238 eventos não notificados pelos empregadores e que representaram uma redução da subnotificação da ordem de $25 \%$ em relação ao total de 2.138.955 registros contabilizados no período. Além disso, em 2006 a Previdência Social contabilizou a concessão de 140.998 auxíliosdoença por acidentes do trabalho, em 2007 foram 274.946 concessões, o que representa um crescimento da ordem de 95\%. O crescimento ainda foi relevante em 2008, quando foram concedidos 356.336 benefícios, e a tendência de estabilização segue nos anos seguintes, com a concessão de 329.914 e 327.894, respectivamente em 2009 e 2010 (Melo, 2011). 
Portanto, a implementação do NTEP nos sistemas informatizados do INSS, para concessão de benefícios, provocou uma mudança radical no perfil da concessão de auxílios-doença de natureza acidentária, observandose um incremento da ordem de 148\% (Brasil, 2010).

Entre os anos de 2003 e 2009, o custo Brasil com os eventos decorrentes dos riscos ambientais do trabalho foi da ordem de $\mathrm{R} \$ 56,8$ bilhões, sendo que $\mathrm{R} \$ 14,2$ bilhões representa a despesa direta da Previdência Social com pagamento de benefícios acidentários e aposentadorias especiais. O restante (aproximadamente $\mathrm{R} \$ 42,6$ bilhões o somatório de despesas com reabilitação física (assistência e tratamentos médicos), reabilitação profissional e o custo indireto das consequências, entre outros (Melo, 2011).

Vale ressaltar que no Brasil, as estatísticas de agravos relacionados ao trabalho têm sido produzidas ao longo dos anos, a partir dos dados da Previdência Social, e se limitam aos trabalhadores segurados e cobertos pelo Seguro de Acidente de Trabalho, ainda assim, os dados do cenário brasileiro são preocupantes, com coeficientes que alcançam valores quatro a oito vezes maiores que outros países (Brasil, 2013).

No período compreendido entre os anos de 2007 a 2012 observase a magnitude de registros com acidentes biológicos $(n=185.910)$ e acidentes graves em maiores de 18 anos de idade $(n=171.902)$, além de registros de violência no trabalho $(n=6.469)$ e acidentes em menores de 18 anos de idade (10.729), indicando um incremento gradativo na frequência absoluta de registro de acidentes e violência no trabalho em todas as regiões do Brasil (Brasil, 2013).

Entretanto, sabe-se que ainda existe grande subnotificação dos agravos ocorridos com os trabalhadores. Estudo recente sobre a análise dos benefícios auxílio-doença concedidos no estado de Rondônia por exemplo, evidenciou que os transtornos mentais agora começam a 
aparecer entre os benefícios acidentários devido à implantação do Nexo Técnico Epidemiológico Previdenciário (NTEP) pelo INSS. Refere ainda que, os transtornos mentais, as neoplasias e algumas outras enfermidades apresentam dificuldade no reconhecimento do nexo causal pelos médicos, o que contribui substancialmente para o subregistro e pode explicar as baixas taxas de doenças relacionadas ao trabalho encontradas no Brasil (Jakobi et al., 2013).

Um ponto a ser destacado é a avaliação médico-legal do dano ou agravo e das alterações na integridade psíquica e física, considerando a subjetividade dos profissionais na interpretação das queixas referidas além da possibilidade de simulação pelo trabalhador. Dessa forma, o adoecimento e a incapacidade para o trabalho, são assuntos de grande polêmica e complexidade, tendo em vista as lacunas existentes nas políticas de atenção $\square$ saúde do trabalhador no Brasil. As falhas no processo de avaliação das incapacidades, os diagnósticos tardios, a lentidão nos tratamentos além da falta de conhecimento e preparo dos líderes para acolher o trabalhador que retorna com limitação, são fatores que permeiam a vivência sofrida dos trabalhadores.

Sob essa ótica, evidencia-se que as redes sociais formais configuram-se cada vez mais frágeis diante da precarização da Previdência Social e da perda contínua dos direitos trabalhistas e previdenciários. 0 Estado, cada vez menos presente, e as instituições publicas, como sindicato, fazem cada vez menos parte da rede dos trabalhadores (Cockell, Perticarrari, 2011).

Estudo realizado por enfermeiras revelou que um problema observado no processo das restrições de trabalho é a prescrição em série de vários laudos contendo restrições temporárias, até por fim, a restrição definitiva. Este fato mostra a real necessidade de se desenvolver e implementar medidas precoces de prevenção de agravos, na fase aguda, 
utilizando uma equipe multidisciplinar, para evitar este ciclo vicioso, no qual o trabalhador acaba por ser afastado definitivamente das suas atividades laborais (Gurgueira, Alexandre, 2006).

A reabilitação profissional deve ser um processo dinâmico de atendimento integral, que envolva as empresas no processo de prevenção, tratamento, reabilitação, readaptação e reinserção no trabalho. Para isso, são necessárias ações que vão além do programa de reabilitação profissional da Previdência Social e da reabilitação clnica dos diversos serviços de saúde, envolvendo não somente uma equipe multidisciplinar como as próprias instituições, os gerentes e demais trabalhadores que participam do processo de acolhimento ao trabalhador com incapacidade (Mininel, 2010; Toldr $\square$ et al., 2010).

Pesquisa que realizou a adaptação transcultural do Work Disability Diagnosis Interview ( $\square$ o $\square \square \square$ para o contexto brasileiro reforça que os trabalhadores de $\square$ nfermagem vivenciam um ambiente prop cio para o desenvolvimento de incapacidades, as quais desencadeiam afastamentos recorrentes, de longos períodos ou absenteísmos isolados, que mascaram uma preocupante realidade (Mininel et al., 2012).

Além disso, observa-se que o trabalhador da enfermagem com uma trajetória histórica de dedicação intensa ao trabalho, submissão a outros profissionais da área da saúde e exposição constante à condições inadequadas no trabalho se afasta das atividades laborais somente quando seus agravos à saúde se tornam insustentáveis (Silva, 2012; Batista, Juliani, Ayres, 2010, Leite Merighi, Silva, 2007).

À medida em que retarda-se o diagnóstico das lesões e/ou da incapacidade, o tratamento também ocorre tardiamente e a chance do trabalhador retornar às atividades laborais sem restrição, diminuem. Esta situação ocorre com frequência entre os trabalhadores de enfermagem, por mais paradoxal que seja, os trabalhadores retardam a procura por uma 
avaliação médica e tendem a buscar outras medidas para aliviar os sintomas.

Pesquisas têm evidenciado que os trabalhadores de enfermagem praticam a automedicação para alívio das dores e demoram a procurar o serviço médico. Além disso, quando buscam uma avaliação médica, muitas vezes, sentem-se negligenciados quanto à suas queixas, o que os desmotivam na busca pelos tratamentos e pela reabilitação (Tito, 2013; Ratier, 2012; Silva, 2012; Baptista, Merighi, Silva, 2012; Martins, 2011, Barros, Griep, Rotenberg, 2009).

orroborando com os dados apresentados, evidencia-se a crtica realidade brasileira, carente de ações urgentes, resolutivas e permanentes, uma vez que, os trabalhadores vivenciam situações dramáticas sob o ponto de vista de diagnóstico e notificação das incapacidades, além, da utilização dos recursos do sistema previdenciário para afastamentos decorrentes do trabalho (Silva, Baptista, 2013; Mininel, 2010).

O modelo previdenciário de reabilitação profissional brasileiro, marcado pela desassistência, tem levado ao prolongamento do afastamento do trabalho pela permanência da incapacitação, altas precoces pela Perícia Médica do INSS, gerando um sério problema para as instituições, e sofrimento para os trabalhadores. A falta de capacitação tanto dos profissionais de saúde como profissionais de recursos humanos quanto ao atendimento, acompanhamento e orientações de aspectos clínicos, sociais e de direitos trabalhistas do readaptado, evidenciam a escassa visão de integralidade do ser humano nesse processo (Takahashi, 2010, Batista, Juliani, Ayres, 2010).

Nesse contexto desfavorável de demandas migradas da Previdência Social para os Centros de Referência em Saúde do Trabalhador (Cerest), inseriu-se o Programa de Reabilitação Profissional do CerestPiracicaba para adoecidos por LER/DORT (Lesões por Esforços 
Repetitivos/Doenças Osteomusculares Relacionadas ao Trabalho), um projeto-piloto, que possui financiamento conjunto da Secretaria Municipal de Saúde de Piracicaba e do Ministério da Saúde. O Programa tem como pressuposto teórico a reabilitação profissional como um conjunto integrado de ações cuja finalidade é resgatar as capacidades física, psicológica e social dos trabalhadores acometidos por agravos de saúde. Fundamenta-se numa atenção multidisciplinar, composta por uma equipe de médicos, assistentes sociais, psicólogos, fisioterapeutas, terapeutas ocupacionais e sociólogos (Takahashi et al., 2010).

O Programa contempla a avaliação inicial da incapacidade, de forma compreensiva e integral; a abordagem das características e dificuldades que vão emergindo durante a condução dos programas em grupo e que, ao serem discutidas em equipe, possibilitam o desenvolvimento de formas conjuntas para o resgate da capacidade de trabalho; a avaliação final, após o término do programa, quando a equipe conclui pela aptidão para o retorno ao trabalho ou pela sugestão de aposentadoria, considerando-se as capacidades físicas e psicológicas atuais e o retorno ao trabalho, quando a equipe, em conjunto, realiza a avaliação técnica de compatibilidade da função oferecida pela empresa. Do mesmo modo, a prática interdisciplinar é também desenvolvida nas reuniões interinstitucionais entre a equipe do Cerest-Piracicaba e a equipe do Programa Reabilita do INSS (médico-perito, assistente social e terapeuta ocupacional), o que vem possibilitando um fluxo facilitador em reabilitação profissional para os casos de interface entre as duas instituições e uma postura única de negociação com as empresas, minimizando as contradições. Além disso, ocorrem visitas às empresas, com acompanhamento sindical, para negociação das funções compatíveis de retorno ao trabalho, viabilizando espaços interinstitucionais, para o desencadeamento de ações práticas que possam de fato, reabilitar o trabalhador (Takahashi et al., 2010). 
Outra experiência a ser destacada no Brasil, é o Programa de Reabilitação Ampliado (PRA), desenvolvido entre os anos de 2007 e 2008 em Santa Catarina, um projeto piloto de reabilitação profissional do Ministério $\square$ blico do Trabalho, onde uma equipe multiprofissional assistiu os trabalhadores com capacidade laboral residual para exercer outras funções. Dentre estes trabalhadores, $64 \%$ retornaram ou estão retornando ao trabalho e cerca de $7 \%$ foram definitivamente aposentados por apresentarem incapacidade laboral. A realização desta nova proposta de reabilitação profissional, fundamentada em uma abordagem biopsicossocial com a atuação de uma equipe multiprofissional, aponta para o desenvolvimento de outras metodologias para programas de reabilitação no cenário nacional (Bartilotti et al., 2009).

Tratando-se do retorno ao trabalho, internacionalmente destacase o Modelo de Sherbrooke que propõe intervenções integradas, direcionadas ao trabalhador e ao local de trabalho, considerando indispensável o envolvimento de múltiplos agentes na prevenção e recuperação do trabalhador incapacitado, por meio de uma abordagem transdisciplinar ao invés de focar-se, exclusivamente, no tratamento da doença. Pesquisa realizada no Canadá com a implementação do Modelo de Sherbrooke evidenciou que, durante os 6.4 anos de acompanhamento do estudo, houve uma economia para os empregadores de US\$18.585,00 por trabalhador. Além deste impacto financeiro, 293 dias de afastamento do trabalho foram "economizados" nos seis anos de acompanhamento (Loisel, Durand, 2005; Loisel et al., 2002).

Infelizmente, ações integradas, com uma equipe multiprofissional e o envolvimento dos líderes como recomenda o Modelo de Sherbrook ainda são pontuais na realidade brasileira e o cenário das incapacidades laborais tem se tornado um grave problema para a Previdência Social, para os trabalhadores e um constante desafio na gestão de pessoas. 
A literatura brasileira evidencia que fatores não estritamente médicos, como posição socioeconômica, idade, expectativa relativa ao retorno ao trabalho e nível de reposição de renda pelo INSS, influenciam a duração do benefício. Aprimorar o entendimento do processo de determinação da utilização do seguro social/incapacidade para o trabalho também é fundamental para o desenvolvimento de intervenções que diminuam os custos econômicos, sociais e pessoais da incapacidade, bem como para enfrentar a possibilidade de desigualdade social na utilização do seguro (Souza, Santana, 2012).

Considerando que a produtividade é um elemento primordial no mundo do trabalho, julga-se que avaliações desse constructo mereçam especial atenção, principalmente relacionadas aos profissionais da saúde, em virtude da especificidade no processo de trabalho, e suas repercussões no contexto laboral, especialmente relacionadas à qualidade da assistência prestada (Ummann, Guido, Grazziano, 2012).

Tratando-se da qualidade da assistência e da segurança do paciente, o Ministério da Saúde e a Agência Nacional de Vigilância Sanitária (ANVISA) formalizaram o Programa Nacional de Segurança do Paciente por meio da portaria $n^{\circ} 529$, de 1 de abril de 2013, cujo objetivo é promover melhorias relacionadas à segurança do paciente, de forma a prevenir e reduzir a incidência de eventos adversos no atendimento e internação. A Portaria descreve a promoção da cultura de segurança, ressaltando o engajamento dos profissionais na prevenção de incidentes, com ênfase em sistemas seguros, acima de metas financeiras e operacionais (Brasil, 2013).

Esse paradigma pressupõe a condição humana, ou seja, que os humanos erram e a segurança depende da criação de sistemas que antecipem os erros e também os previnam ou os interceptem antes que causem danos (Watcher,2010). 
Diante da importância do engajamento de todos os profissionais na prevenção de incidentes, vale destacar a atual crise da força de trabalho identificada no setor saúde, caracterizada pela escassez de recursos humanos, ausência de planos de carreira, precarização dos vínculos, entre outros, o que pode tornar ainda mais frágil a segurança dos pacientes.

A Organização Mundial de Saúde dedicou o ano de 2006 e a década iniciada nesse ano, aos trabalhadores da saúde, sendo também o tema do "Relatório Mundial da Saúde de 2006 Trabalhando juntos para a saúde". O relatório propõe a construção de um plano decenal, orientando que os países busquem formas de planejamento, qualificação e empregabilidade e fixação de médicos, enfermeiros e auxiliares de enfermagem. Para tanto, impõem-se aos gestores de Recursos Humanos em Saude (RHS), desafios gerenciais diversificados e cada vez mais complexos pelas transformações e exigências do trabalho contemporâneo, desde a inserção de trabalhadores no serviço (que se apresentam sob formas variadas), a distribuição, a fixação, a qualificação, o resgate de padrões éticos, mas, sobretudo, da incorporação de qualificações gerenciais à área de RHS para lidar com todo esse processo em transformação (Pierantoni, et al., 2008, Gupta, 2008).

Nesse sentido, cabe destacar no processo de trabalho do enfermeiro, a dimensão gerencial, em que os objetos de trabalho são a organização do trabalho e os recursos humanos de enfermagem. Para execução deste processo, ao longo dos tempos, a enfermagem vêm desenvolvendo um conjunto de saberes, que permitem ao enfermeiro utilizar instrumentos técnicos próprios da gerência como o planejamento, o dimensionamento de pessoal, o recrutamento e seleção, a educação permanente e outros ( Felli, Peduzzi, 2010, Costa e Silva, Peduzzi, 2006). Portanto, é responsabilidade gerencial do enfermeiro atentar para os problemas de saúde dos trabalhadores de enfermagem, uma vez que a 
qualidade da forca de trabalho impacta diretamente na qualidade da assistência de enfermagem dispensada aos pacientes.

A compreensão e reflexão a respeito da forma como os processos de readaptação dos trabalhadores incapacitados se desenvolvem e suas implicações para o gerenciamento, são essenciais, uma vez que nesse processo, se pode identificar implicações de ordem pessoal, social, gerencial, com importantes repercussões na assistência de enfermagem prestada ao cliente e, a garantia de qualidade assistencial torna-se possível na medida em que há o envolvimento da instituição na valorização do trabalhador e das respectivas condições de trabalho (Batista, Juliani, Ayres, 2010).

Assim, compreender a ação de gerenciar a força de trabalho em enfermagem incapacitada sob a ótica de gerentes de enfermagem torna-se extremamente relevante, na medida em que os gerentes são os sujeitos que vivenciam esta experiência, a partir da mobilização de seus conhecimentos, recursos internos e recursos institucionais.

Ponderando sobre os dados apresentados acerca da problemática realidade da enfermagem brasileira, caracterizada por uma força de trabalho insuficiente em termos quantitativos e qualitativos, aliadas às condições precárias de trabalho, com baixa remuneração, equipamentos obsoletos, contato diário com a dor, o sofrimento e a morte, e os dados da literatura acerca da incapacidade, apresento a seguir o referencial teórico metodológico escolhido para o desenvolvimento do presente estudo. 
3. Referencial Filosófico de Alfred Schütz e o Contexto do Estudo 
Para compreender a ação de gerenciar a força de trabalho em enfermagem incapacitada sob a ótica de gerentes de enfermagem, é necessário entender o gerente como um ser de relação, que interage com o mundo e com as coisas do mundo. O gerente de enfermagem como um ser dotado de relações, que vivencia as questões de adoecimento e incapacidade dos trabalhadores de enfermagem, interage com as lideranças imediatas, e sobretudo, um indivíduo que possui comprometimento com a qualidade da assistência de enfermagem prestada aos pacientes. Nesse sentido, optou-se utilizar o referencial teórico-metodológico da fenomenologia social, para compreender esta experiência, que é essencialmente social, do mundo da vida, do cotidiano de relações, e de projetos de ação que motivam os gerentes de enfermagem para o futuro no contexto de trabalho.

A fenomenologia é uma abordagem que se destina à compreensão dos fenômenos, como abordagem metodológica, caracterizase por descrever as experiências humanas traduzidas sob a percepção dos sujeitos. Nesse contexto, vislumbra traduzir as experiências vivenciadas pelos indivíduos, no mundo da vida, num contexto social, cultural, a partir da sua essência (Wagner, 2012).

A fenomenologia tem sido descrita como um movimento filosófico e uma abordagem adequada para a pesquisa em ciências humanas e este método particular tem sido empregado em disciplinas profissionais, como educação, enfermagem, psicologia clínica, entre outras, com expressiva contribuição no desenvolvimento do conhecimento de enfermagem (Earle, 2010).

$\mathrm{Na}$ fenomenologia destacam-se correntes filosóficas como a fenomenologia existencial, fenomenologia social, as quais têm sido empregadas nas pesquisas na área da saúde com o propósito de descrever as experiências humanas, sejam dos pacientes, familiares ou dos 
profissionais, com vistas à melhor e mais aprofundada compreensão dos processos de adoecimento, sofrimento, morte e relação de cuidado.

A opção pelo referencial da fenomenologia social de Alfred Schütz deve-se ao fato de que investigar a ação de gerenciar a força de trabalho em enfermagem incapacitada sob a ótica de gerentes de enfermagem, remete-se à uma ação concreta vivenciada por um determinado grupo social, em um mundo que é essencialmente um mundo de relações, repleto de intenções, circunscrito em uma dimensão social.

Alfred Schütz nasceu na Áustria, em 1899, e faleceu nos Estados Unidos, em 1959. Graduou-se em Direito e Ciências Sociais e como profundo conhecedor da filosofia de Edmund Husserl e da sociologia da ação de Max Weber propôs uma síntese entre a fenomenologia e a sociologia. As bases do seu pensamento estão nas obras desses autores, além de outras influências como Bergson, James, Scheler, Dewey, Mead, entre outros (Souza, 2012).

Nesse aspecto, o autor propõe um entendimento fenomenológico do social, com base na experiência cotidiana, onde ele define a sociologia como uma hermenêutica da ação social, uma vez que descreve uma sociologia interpretativa, pela busca dos sentidos (Wagner, 2012).

A primeira obra de Schütz Der Sinnhafte Aufbau der Sozialen Welt -A construção significativa do mundo social- foi publicada em Viena, no ano de 1932 sendo considerada uma obra clássica para compreender a síntese dos pensamentos de Husserl e Weber, em que Schütz faz uma análise mais detalhada dos fundamentos das estruturas sociais. $O$ autor publicou em vida, textos, a maioria deles em inglês, alguns traduzidos para os idiomas francês, alemão e espanhol. Postumamente, foram publicados no idioma inglês os três volumes dos Collected Papers, contendo grande parte de seus postulados (Wagner, 2012; Schütz, Luckmann, 2009). 
A seguir, são apresentados alguns conceitos propostos por Schütz, os quais fundamentam o fenômeno que se pretende investigar na presente pesquisa.

Sch $\square$ tz debruça-se sobre o mundo da vida social, recorrendo à um método de an\lise descritiva da constituição da experiência cotidiana. Prefere descrever a realidade do mundo da vida cotidiana, como sendo uma realidade social, partindo de estruturas sociais de significados desde que nascemos e ao longo da nossa existência junto com outros semelhantes. Sendo assim, desde que nascemos estamos em um contexto relacional de motivação recíproco com estruturas de significado que se constituem um acervo social de conhecimento. O autor reconhece que o conhecimento e a sociedade estão entrelaçados, tanto o conhecimento geral como específico, em uma matriz de ação e experiências compartilhadas e condicionadas por outros (Schütz, Luckmann, 2009).

Schütz define atitude natural como uma consciência que, estruturada, organiza o conjunto das experiências como depósitos, sedimentos, compondo com isso um "arquivo" de conhecimentos adquiridos ao longo da vida, pelas suas experiências vividas ou apreendidas com seus antepassados (Wagner, 2012). Assim, a atitude natural, é composta pelo acervo de conhecimentos dos gerentes de enfermagem adquiridos não apenas na formação profissional mas, ao longo da vida, com todas as suas experiências, sejam elas pessoais e profissionais, conformando uma bagagem de conhecimentos disponíveis.

Para Schütz, o homem da atitude natural está situado biograficamente no mundo da vida, mundo no qual ele deve agir junto aos seus semelhantes, tendo posse da sua bagagem de conhecimentos construídos biograficamente, compondo a situação biográfica. A situação biográfica, é um conceito descrito por Schütz e não se trata apenas de um 
ponto de vista, mas uma íntima relação com a história de vida pessoal de cada um dos membros de um grupo social.

Nesse sentido, a atitude dos gerentes de enfermagem se dá biograficamente, de modo natural, no mundo da vida, pois se trata de uma atitude correspondente a sua sedimentação e acervo de conhecimento, pressupostos que lhe foram dados desde o nascimento e adquiridos ao longo da sua história de vida, sua formação profissional e suas experiências. Dessa forma, a vivência dos gerentes é influenciada ou até mesmo determinada pelas anteriores, que fazem parte do acervo de conhecimento disponível e da própria biografia de cada uma delas no mundo da vida.

$\mathrm{Na}$ atitude natural, o homem sempre se encontra em um mundo que se pressupõe evidentemente ser um mundo real, onde se experimenta a intersubjetividade. A intersubjetividade evidencia a existência corporal de outros homens, onde esses corpos são dotados de consciência e as coisas do mundo externo são semelhantes para todos os homens (Souza, 2012; Schütz, 2008; Schütz, Luckmann, 2009).

Considerando o objeto de estudo a ser investigado a ação de gerenciar a força de trabalho em enfermagem incapacitada sob a ótica de gerentes de enfermagem, a intersubjetividade é ponto central no cotidiano dos sujeitos, uma vez que os gerentes precisam estar numa relação constante com os trabalhadores de enfermagem que apresentam limitação, com as equipes de enfermagem que acolhem os trabalhadores após longos períodos de afastamento para tratamento, com a equipe multiprofissional, com suas lideranças imediatas e com seus pares.

Ainda, acerca da intersubjetividade descrita por Schütz, destaca-se que a efetividade nos Programas de Retorno ao Trabalho com vistas à readaptação do trabalhador com incapacidade envolvem uma série de atores, onde o cuidado compartilhado torna-se imprescindível para o sucesso do retorno ao trabalho de trabalhadores com incapacidade. 
Portanto, a intersubjetividade descrita na relação face a face gerente de enfermagem-trabalhador de enfermagem.

Tendo em vista o fenômeno a ser estudado, observa-se que o cenário do trabalho de enfermagem tem sido marcado por baixos salários, escassez de recursos humanos, ocorrência de acidentes, adoecimento e incapacidades, temporárias e/ou permanentes. Esse cotidiano faz parte do mundo da vida, no qual se insere toda e qualquer ação com vistas à melhoria da gestão de recursos humanos por parte dos gerentes de enfermagem.

O mundo da vida, para Alfred Schütz, é um mundo cultural e intersubjetivo, uma vez que outros homens coexistem e convivem entre si, de múltiplas formas de interação, em diversos graus de intimidade e anonimato, não apenas na maneira corporal, mas também como seres dotados de uma consciência que é essencialmente similar (Schütz, Luckmann, 2009).

O mundo da vida cotidiana é caracterizado, então, pela suposição da existência do mundo; e, por ser um mundo prático, as questões que mobilizam nele voltam-se à prioridade da prática, das respostas às necessidades impostas pela vida - é o motivo pragmático de que fala Schütz, o mundo aparece como algo diante do qual enfrentamos ou cedemos (Souza, 2012).

No mundo da vida, a problemática de adoecimento e incapacidade dos trabalhadores de enfermagem, torna-se foco de preocupação para os gerentes, tendo em vista, a sua repercussão na qualidade dos serviços de saúde, especialmente no que se refere à qualidade da assistência de enfermagem e à segurança do paciente. Assim, para compreender o processo de adoecimento e incapacidade sob a ótica dos gerentes de enfermagem, é necessário desvelar o cotidiano desta vivência, permeada de conflitos e dificuldades, entretanto com inúmeros 
saberes, os quais podem ajudar a composição de uma rede de significados, com vistas à ações futuras, para essa realidade tão preocupante na enfermagem brasileira.

Para Schütz, a compreensão da conduta dos outros é possível mediante o exame do processo de tipificação. Ou seja, podemos compreender as condutas se descrevermos os esquemas de interpretação apreendidos e utilizados pelos atores para entender o significado do que estão fazendo, fazem ou fizeram. A ação é definida por Schütz, como uma conduta humana projetada pelo sujeito de maneira autoconsciente, intencional, que não est $\square$ isolada, ou dissociada do mundo da vida. Manifesta ou latente, a ação tem uma tipificação que tem como cerne a vida de sentido comum, onde o sujeito atua de modo típico, em uma dada situação para produzir uma situação tipicamente similar (Schütz, 2008; Souza, 2012).

As tipificações são como receitas que congregam características gerais e homogêneas para certas situações, coisas e contextos. Na nossa vida temos várias formas de tipificar: no nomear; pelas instituições que tipificam as ações, as pessoas, os contextos, os procedimentos e os comportamentos (Souza, 2012).

O contexto dos gerentes de enfermagem possui características que lhe são próprias, as quais podem ser tipicamente observadas no cotidiano de trabalho, nas relações circunscritas, independente da instituição e região na qual a mesma se insere. Essas ações podem ser tipificadas a partir das caraterísticas que são próprias desse grupo social, os gerentes de enfermagem inseridos no cenário brasileiro.

Assim, o tipo vivido não se refere a uma pessoa, em particular; mas, aos esquemas idealizados do mundo da vida de um grupo de indivíduos com características que são típicas, num determinado contexto hist $\square$ rico-social, com motivos em vista dos quais agem, onde a linguagem e 
a comunicação desempenham um papel tipificamente importante (Schütz, Luckmann, 2009; Schütz, 2008).

Nessa perspectiva, gerenciar a força de trabalho incapacitada perpassa pelas questões do quantitativo e qualitativo de pessoal mas, acima de tudo, estão presentes as necessidades de cuidado dos pacientes, e as questões ético-legais para assegurar a qualidade da assistência de enfermagem no cotidiano de trabalho. Somado a isso, a ação dos gerentes de enfermagem também está baseada em todo acervo de conhecimento, que vai além dos saberes profissionais, mas emerge da sedimentação de experiências do mundo da vida, para que estratégias sejam implementadas com vistas à proteção da força de trabalho, minimizando os agravos à saúde dos trabalhadores.

Para Schütz, a experiência se sedimenta por meio de contextos numa ação social, onde o ator social usa conhecimentos ordinárias com os quais possa dar conta de atividades sociais. Assim, surgem os motivos porque, os quais fundamentam uma dada vivência, exigindo uma reflexão/retrospectiva acerca da bagagem de conhecimentos que motivaram determinada ação (Souza, 2012; Castro,2012).

A ação pode ser definida como um projeto, ou seja, a ação é a antecipação de um estado futuro, onde o sentido e o motivo não são suficientes na definição da ação e sim o projeto que estabelece o seu começo e o seu fim. O projeto dá o escopo da ação, pois com o ele os eventos são antecipados, como motivo para (a fim de) como idéia de futuro, de projeção e o ator social planeja a partir de idealizações, suas ações futuras, expressando confiança na estrutura básica do mundo da vida (Souza, 2012).

Assim, Schütz discute a subjetividade, numa perspectiva sociológica, estabelecendo a matriz de uma idéia de intersubjetividade que supera as subjetividades individuais. Logo, o objetivo da fenomenologia 
social não $\square$ investigar o comportamento de cada indiv duo em particular mas, sim, o que se pode constituir em uma característica típica de um grupo social que vivencia determinados comportamentos em suas relações $\mathrm{m}\lfloor$ tuas e com forte significado subjetivo (Castro, 2012; Capalbo,1998).

A compreensão do fenômeno ação de gerenciar a força de trabalho em enfermagem incapacitada sob a ótica de gerentes de enfermagem pretende desvelar a vivência de gerentes no contexto da incapacidade laboral dos trabalhadores de enfermagem (motivos porque) e a intencionalidade das ações (motivos para), as quais são descritas por meio de categorias concretas que configuram o tipo vivido.

O tipo ideal é a expressão de uma problemática do fenômeno social e contém seu próprio princípio de constituição e representa um valor conscientemente selecionado pelo pesquisador. Esses valores se mostram fecundos para a compreensão dos fenômenos, em que se faz necessário organizar os dados subjetivos e, descrever o vivido, trazendo-o para a ordem das significações. $\square$ ste princ pio $\square$ o ponto-chave na an $\square$ lise e compreensão das ações (Zeferino, Carraro, 2013; Capalbo,1998).

Além disso, faz-se necessário considerar a situação biográfica do ator estudado, uma vez que os "motivos porque" s $\square$ poderão ser compreendidos mediante o conhecimento da sua hist $\square$ ria de vida, daquilo que levou este sujeito a praticar tais ações. Esses motivos estão enraizados na sua personalidade, no aprendizado que acumulou por toda a vida; só conhecendo o seu passado $\square$ que se tem a possibilidade de conhecer o tipo de mente que empreendeu tal ação (Zeferino, Carraro, 2013).

Assim, por meio da experiência vivida pelos enfermeiros no processo gerencial e considerando o histórico das significações frente à incapacidade dos trabalhadores de enfermagem, será possível olhar para uma ação atrelada ao mundo social, onde os motivos que a justificam, permeiam todo o processo de trabalho. 
A partir da compreensão dos significados individuais pela correspondente an $\square$ lise e junção em categorias, $\square$ que se pode conhecer o conjunto de conteúdos típicos capazes de descrever as intenções de tais ações, constituindo os "motivos para". \essa forma, entende-se que a significação com que se designa uma ação $\square$ interpretada pelo ator a partir dos seus motivos "porque" e "para", e a reunião desses motivos formam as categorias das ações humanas pass veis de an $₫$ ise ( $\sqsubset$ eferino, $\square$ arraro,

Nesse sentido, ao buscar a compreensão desta experiência, tendo como arcabouço filosófico o referencial de Alfred Schütz, acredita-se ser possível descrever a complexidade do processo de gerenciar a força de trabalho incapacitada, trazendo à tona todas os dilemas enfrentados pelos gerentes, podendo estes dados subsidiarem o delineamento de caminhos para que a incapacidade da força de trabalho em enfermagem seja revista e repensada em cenário nacional. 
4. Trajetória Metodológica 


\subsection{Tipo de pesquisa}

Trata-se de uma pesquisa qualitativa fenomenológica, pois esta vertente teórico-metodológica possibilita acessar a consciência dos sujeitos, buscando neste estudo, compreender o modo como as gerentes de enfermagem vivenciam o processo de gerenciar a força de trabalho em enfermagem incapacitada. Nesta vertente, optou-se pela fenomenologia social de Alfred Schütz, considerando o objeto de estudo "ação de gerenciar a força de trabalho em enfermagem incapacitada sob a ótica de gerentes de enfermagem", uma ação do mundo da vida que se concretiza num contexto social, marcado pela intersubjetividade.

\subsection{Região de inquérito e cenário da pesquisa}

Segundo Merighi e Praça (2003), região de inquérito é a região da perplexidade, o local das preocupações do pesquisador. Desta forma, não se trata de um espaço físico e sim de um contexto conceitual no qual as pessoas agem. Neste estudo, a região de inquérito foi constituída por indivíduos designados diretores de serviço de enfermagem e/ou ou gerentes de enfermagem, excluindo-se indivíduos nomeados como diretores e/ou gerentes que não respondessem direta ou indiretamente pela força de trabalho em enfermagem de hospitais públicos universitários federais brasileiros.

O cenário da pesquisa foi composto por 5 hospitais universitários federais brasileiros, considerando a representatividade regional (Sul, Sudeste, Norte, Nordeste e Centro-oeste). Todos os hospitais são de grande porte, referência em média e alta complexidade no Estado e integrante do Sistema Único de Saúde (SUS). Possuem estrutura tecnológica e instrumental técnico para o atendimento de casos da alta complexidade e consultas especializadas, realizando exames avançados de diagnóstico e 
procedimentos cirúrgicos. Além disso, vinculam-se às universidades federais, colaborando na formação de diversos profissionais da área da saúde.

É importante destacar que não foram descritas informações especificas de cada instituição, as quais pudessem identificar o cenário no qual cada gerente atua, com o intuito de preservar o anonimato dos dados relatados.

\subsection{Sujeitos da Pesquisa}

Em princípio, foi realizado o contato telefônico com os diretores/ gerentes de enfermagem de hospitais universitários federais brasileiros, considerando a representatividade regional (Sul, Sudeste, Norte, Nordeste e Centroeste), explicitado os objetivos da pesquisa e o convite para a participação. Após o aceite, foi agendado um encontro para a realização de entrevistas em cada cenário regional. Em alguns cenários foram indicados mais de um sujeito para participar da pesquisa, considerando a sua proximidade com o objeto de estudo. Todo este processo foi realizado individualmente até que as inquietações a respeito do fenômeno fossem respondidas, totalizando 12 entrevistas realizadas com gerentes de enfermagem, do sexo feminino, dos cenários sul, sudeste, centro-oeste, norte e nordeste. Para a composição do estudo foram utilizadas 9 entrevistas, considerando que as demais não responderam ao objeto do estudo.

As entrevistas ocorreram em um ambiente privativo, livre de barulho e interferência, eleito pelas gerentes de enfermagem dos cenários. A fim de preservar o anonimato de cada uma das enfermeiras entrevistadas, os discursos foram identificados pela letra "G"-Gerente, acompanhada de números arábicos, conforme a ordem de obtenção das mesmas. 
Apresento, a seguir, as características da situação biográfica das participantes do estudo:

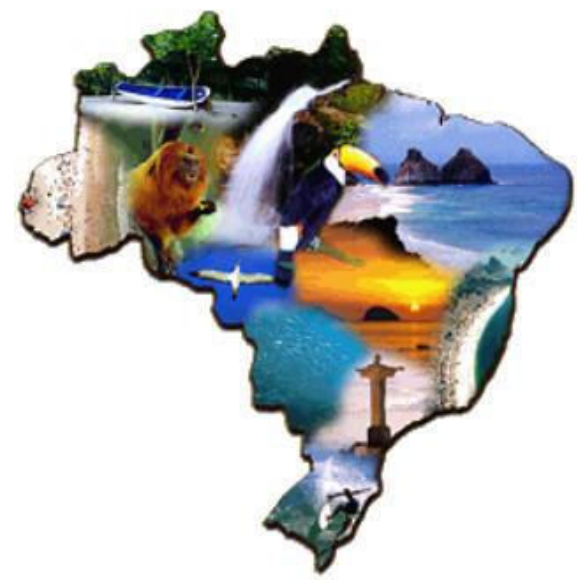

G1. 43 anos de idade, 25 anos de formada, 08 anos na Diretora de Enfermagem e 25 anos de experiência em gestão;

G2. 61 anos de idade, 32 anos de formada, 8 anos no cargo Diretora de Gestão e 20 anos de experiência em gestão;

G3. 54 anos, 28 anos de formada, 8 anos no cargo de Assessora de desenvolvimento de pessoase 22 anos de experiência em gestão;

G4. 50 anos de idade, 23 anos de formada e experiência em gestão e 1 ano e meio como Diretora de Enfermagem;

G5. 48 anos de idade, 23 anos de formada, 11 anos de experiência em gestão e 1 ano e meio como Vice Diretora;

G6. 50 anos de idade, 8 anos no cargo de Diretora de Enfermagem e 17 anos de experiência em gestão;

G7. 48 anos de idade, 21 anos de formada, 12 anos de experiência em gestão e 1 mês como Diretora de Enfermagem;

G8. 52 anos de idade, formada há 17 anos, diretora de enfermagem há 12 anos;

G9. 45 anos de idade, 20 anos de formada, 14 anos de experiência em gestão.

\subsection{Procedimentos para coleta de dados}

O projeto foi submetido ao Comitê de Ética em Pesquisa da Escola de Enfermagem da Universidade de São Paulo, e aprovado sob o $\mathrm{n}^{\circ}$ 378.047. De acordo com a Resolução n 466/12 sobre pesquisa envolvendo seres humanos, os sujeitos receberam uma via do Termo de Consentimento, Livre e Esclarecido (TCLE) e foi-lhes reservado o direito de aceitar ou não a participar do estudo (Apêndice 1). 
Para alcançar o objetivo proposto e responder às inquietações desta pesquisa, foram agendadas entrevistas de acordo com a disponibilidade das gerentes, em local acordado com as mesmas, efetuadas por meio de duas questões norteadoras:

Como é para você ser gerente/ diretor de enfermagem e conviver com 0 adoecimento e incapacidade dos trabalhadores de enfermagem no cotidiano do seu trabalho?

O que você espera da sua gestão em relação à incapacidade dos trabalhadores de enfermagem?

Foi realizada a gravação de todas as entrevistas em IPAD e aparelho gravador digital, a fim de promover maior liberdade de expressão e maior fidelidade no processo de captação das idéias. Cada entrevista teve uma média de duração de três horas.

Imediatamente após a realização das entrevistas, os discursos foram transcritos, respeitando a sequência, a linguagem, as pausas e a repetições realizadas.

\subsection{0 caminho para a análise dos discursos}

Para a análise dos discursos inicialmente realizou-se a transcrição de cada entrevista na íntegra, e em seguida, a leitura e releitura de todo o conteúdo, a fim de apreender os trechos significativos buscando compreender em todas eles a essência da viv $\llbracket$ ncia dos gerentes de enfermagem. releitura atenta objetivou detectar os núcleos de pensamentos convergentes ou os núcleos que se referiam à uma dada temática. 
A partir desse agrupamento, tendo como referencial teórico, a fenomenologia social de Alfred Schütz, foram construídas as categorias concretas do vivido, típicas da ação de gerentes de enfermagem diante da incapacidade dos trabalhadores de enfermagem. Essa tipificação, ou seja, a constituição do tipo vivido e a literatura relacionada à temática em questão, embasaram a análise e discussão do objeto de estudo desta pesquisa.

Apresento a seguir, um esquema das etapas que subsidiaram o processo de análise dos discursos:

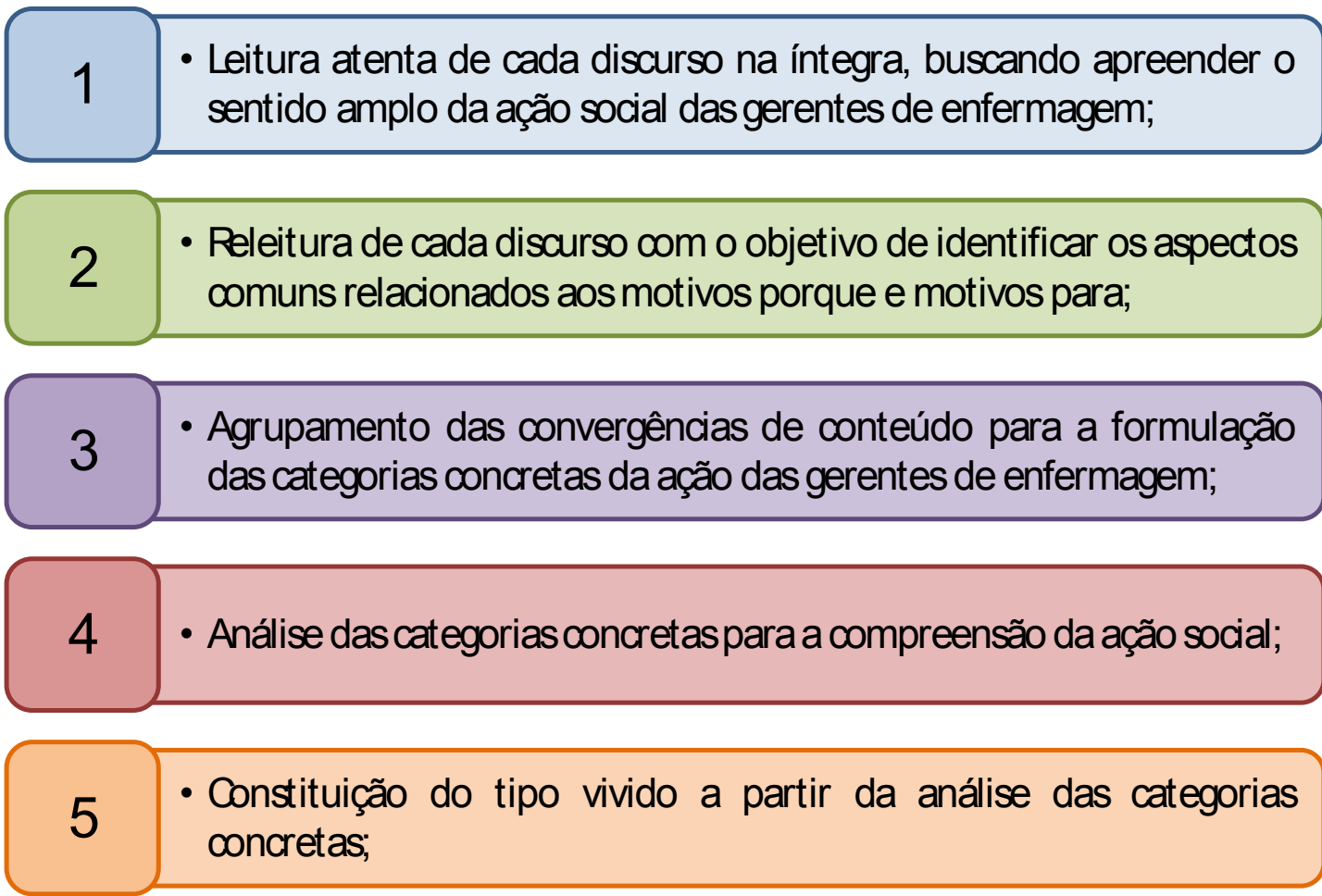
Alfred Schütze outros referenciais da temática. 
5. Resultados 


\subsection{As Categorias Concretas do Vivido}

A compreensão da ação de gerenciar a força de trabalho em enfermagem incapacitada sob a ótica de gerentes de enfermagem permitiu a organização e análise de categorias concretas, as quais descrevem a vivência das enfermeiras gerentes no contexto da incapacidade laboral dos trabalhadores de Enfermagem (motivos porque) e a intencionalidade das ações dos gestores para essa problemática (motivos para), conforme o referencial de Alfred Schütz.

Os depoimentos coletados evidenciaram um conteúdo expressivo da vivência de enfermeiras gerentes diante da incapacidade da força de trabalho em enfermagem, marcada por um trabalho incansável, a fim de assegurar a qualidade da assistência e preservar a saúde dos trabalhadores além de evidenciar também um olhar para o futuro, em que as mesmas projetam as ações que vislumbram e descrevem suas expectativas.

A análise resultou, portanto, na elucidação de duas categorias: $\boldsymbol{A}$ experiência de gerenciar a força de trabalho incapacitada e $A$ expectativa para a gestão de pessoas. A categoria $A$ experiência de gerenciar a força de trabalho incapacitada, abarca o reconhecimento do contexto de adoecimento dos trabalhadores de enfermagem, a angústia para garantir a segurança do paciente e preservar a saúde dos trabalhadores, o prazer no processo de gerenciar e a organização do trabalho no contexto das incapacidades. A categoria A expectativa para a gestão de pessoas, evidencia a importância de construir uma gestão mais participativa, o investimento em uma política de recursos humanos e ainda, o delineamento de novos caminhos.

A seguir, apresento o conteúdo expresso nas duas categorias concretas identificadas a partir dos discursos das gerentes de enfermagem. 


\subsubsection{A experiência de gerenciar a força de trabalho incapacitada}

O cotidiano das enfermeiras na ação de gerenciar a força de trabalho incapacitada é caracterizado por um processo que inclui a percepção e reconhecimento da problemática, o que gera sentimentos de angústia e preocupação com a qualidade da assistência de enfermagem e a segurança do paciente. Apesar desse contexto desgastante, as gerentes sentem prazer no processo de trabalho gerencial e buscam organizá-lo com vistas à redução dos agravos aos trabalhadores e manutenção da qualidade da assistência (motivos porque).

5.1.1.1. O reconhecimento do contexto de adoecimento e incapacidade dos trabalhadores de enfermagem

A análise dos discursos possibilitou a percepção de que as gerentes de enfermagem reconhecem o contexto de adoecimento e incapacidade dos trabalhadores de enfermagem nos diferentes cenários brasileiros.

O adoecimento, o absenteísmo e as inúmeras restrições laborais são elementos destacados nos discursos:

Como eu falei, na enfermagem o índice de absenteísmo é alto... Então essa é uma coisa que a gente está vendo que o índice de absenteísmo na enfermagem aumentou muito, muito, muito (G2).

(...) a gente trabalha com uma taxa de absenteísmo, relativamente no nosso hospital, grande, por conta desse adoecimento (G4).

Eu acho que está doente. Assim, principalmente psicologicamente. E aí, o que acontece?, quando 
começa... o teu corpo chega uma hora que ele vai... dar uma resposta para isso... (G8).

Para mim o adoecimento nosso aqui ele é muito alto e não é mentira não, o povo está doente (G1).

O que eu tenho percebido é o seguinte: a equipe tem adoecido. Aí eu queria saber... gente, o que é que está adoecendo esse servidor nosso (G3).

Esse é o grande nó nosso, na gerência... eu estou com uma lista aqui de absenteísmo... assim... fico... horrorizada (G7).

O aumento progressivo das doenças e das incapacidades dos trabalhadores é percebido pelas gerentes de enfermagem ao longo dos anos por meio da experiência de trabalho, onde elas referem a gravidade da situação de saúde da força de trabalho em enfermagem:

São poucos funcionários, é uma escala estreita. E consequentemente o nível de adoecimento é maior. Então hoje... digamos... de seis anos para cá, cada ano está sendo mais difícil. É um índice enorme de atestados, de afastamentos a longo prazo...(G8).

Esse tempo todo que eu tenho lidado com a enfermagem, $E$ eu vejo só o pessoal adoecendo.. ...o hospital foi crescendo, fomos perdendo coisas, fomos perdendo... Porque a instituição é isso, quando ela pensa em crescer a primeira coisa que ela pensa é em sacrificar, quem?, sacrifica o servidor, o servidor... Então assim... já passei por vários recrutamentos de pessoal e só vejo o quadro do pessoal nosso diminuindo... hoje estou estarrecida... (G3). 
À medida que o tempo foi passando não sei se a vivência nos casos de gestão tem me propiciado esse saber ou essa vivência mais de perto. Mas assim, a impressão que eu tenho é que a categoria tem adoecido mais (G5).

Então, aumentou a demanda de trabalho, mudou o perfil do hospital e não se trabalhou isso nas pessoas...(G7).

Os discursos das gerentes de enfermagem evidenciam as transformações institucionais, como o crescimento do hospital, o aumento da complexidade do cuidado e consequentemente, o agravamento das doenças e da incapacidade laboral.

Ao reconhecer a problemática do adoecimento e incapacidade da força de trabalho em enfermagem, as gerentes destacam o ritmo intenso de trabalho, a inadequação dos recursos materiais e outras cargas de trabalho geradoras de processos de desgaste como os distúrbios osteomusculares e as alterações psíquicas:

Então assim, a gente vive o adoecer... é uma coisa real mesmo que a gente vive no dia a dia. ... assim... depressão... eh... com sintomas bem característicos mesmo de adoecimento mental...ansiedade...eh..., confusos, de você ter que fazer um encaminhamento para a psiquiatria mesmo (G5).

Problema de coluna, problema de ombro... então assim... a maioria é problema de coluna mesmo... na questão de levantar peso (...) e tem algumas pessoas com problema psicológico assim... eh... a maioria por depressão assim... (G9). 
Problema de coluna, a maioria. Problema de artrite, de LER (...) mental também é um dos maiores aqui... Então a doença mental ela hoje... está assim... aumentando de uma forma dentro da instituição... eu acho que tem muito a ver com tudo isso, o stress... porque a gente sofre... (G7).

Trabalhar à noite, então a memória já fica um pouco débil, vai esquecendo o nome de algumas pessoas, então assim... você vê claramente que é um sintoma mesmo de desgaste físico, da sobrecarga...(G5).

No trecho a seguir as gerentes de enfermagem destacam que a invisibilidade do adoecimento mental no trabalho e suas repercussões na equipe de enfermagem, tendo em vista que muitas vezes, a aparência do trabalhador oculta o sofrimento mental:

Os principais problemas nossos são os problemas osteomusculares e psiquiátricos, então não dá. É excesso de trabalho. (...) mas como você sabe? -, - ela não está mentindo, ela está doente mesmo...ela não pode! porque assim, as pessoas olham muito...o físico, está bonita...está bem vestida, você entendeu?...e eu falo, gente, está mal...você não sabe como está por dentro, né? (G3)

Tem casos que eu conheço de perto. Tem uns que chegam aqui para conversar comigo, eu não sou médico nem nada, mas só de conversar eu sei que não tem condição de trabalhar. Eu falo - você não volta -. Então... não tem condição (G1). 
Outro dado importante trazido nos discursos são as transformações advindas do mundo contemporâneo, marcadas por acúmulo de atividades, múltiplos vínculos empregatícios, exigência de qualificação, somados muitas vezes à uma vida pessoal difícil e sofrida das trabalhadoras, predominantemente mulheres, com responsabilidades que transcendem às responsabilidades profissionais, como o cuidado da casa, do marido e dos filhos:

E assim... parece que... a vida das pessoas está muito difícil. O pessoal da enfermagem parece que assim... é marido ruim... assim... quando não tem, procuram uma pessoa assim que... aí... eh... dão tudo e ficam sem nada. E é confusão com filho... e é com neto. Então, parece que é uma confusão. Então assim... uma condição muito difícil de vida...(G9).

Então, aquela coisa de julgar o outro, aquela coisa de dizer - ah, você trabalha em dois porque você quer -, não é porque você quer, a coisa é muito...mais profunda. A gente não sabe da história de vida de cada um. Então as mulheres estão ali na rua, trabalhando, sustentando famílias, filhos e netos... muitas vezes até netos, é uma geração que sustenta netos também (G5).

Porque aqui nós temos um quadro... eh... assim... a maioria são mulheres, a maioria trabalha em mais de um emprego, a maioria são arrimos de família mesmo, às vezes não fazem casamentos que valem à pena, que você sabe disso, que a nossa história é assim. A maioria quer ficar melhor na vida então entra para a faculdade. Aqui tem gente que tem 2 ou 3 empregos, faz faculdade, tem filho pequeno e ainda tem um marido para cuidar. $E$ isso daí desestrutura qualquer ser humano (G1). 
É uma área muito difícil, uma categoria com uma remuneração muito aquém do que a gente na verdade necessita, então você tem uma categoria que precisa trabalhar em dois ou às vezes em três... locais... hospitais ou instituições de saúde para conseguir ter uma renda que atenda às necessidades dessa população (G5).

O trabalhador nosso ele realmente está adoecendo. Está adoecendo por que?, porque o poder aquisitivo nosso diminuiu, porque as pessoas tiveram que arrumar dois... três... quatro... nós temos aqui servidor que está até com cinco vínculos aqui (G3).

...A grande maioria das pessoas tem dois empregos..., além de ter dois empregos ainda elas querem fazer esse plantão para ganhar, porque paga bem. Final de semana... Elas devem receber cobrança em casa... né... não fica em casa. Então tem filhos... tem tudo isso....(G2).

Chama a atenção neste estudo, que várias das gerentes entrevistadas cumprem a dupla e tripla jornada, acumulando atividades profissionais em mais de um hospital além da vida doméstica. Esse dado corrobora com o a realidade vivenciada pelos trabalhadores de enfermagem brasileiros, predominantemente mulheres, com sobreposição de vínculos empregatícios, como apresentado no seguinte trecho:

Então a gente sabe como é...várias realidades... em hospital privado, em público, unidade de saúde... então assim, a gente conhece bem. Não é fácil. E eu pessoalmente que trabalho também em outra instituição ainda, não consegui me livrar do segundo emprego ainda, então eu sei muito bem como é (G5). 
Eu também trabalho em outra instituição, que tem os mesmos problemas e... sou mãe, dona de casa... (G4).

Então assim... geralmente essas pessoas elas têm mais de um emprego... um... dois... Eu mesma, tenho dois empregos. Por que?, porque nós precisamos... quem quer um padrão de vida vai em busca dele, em busca dos seus sonhos... E muitas vezes a gente sabe que o profissional da área da saúde ele é muito mal remunerado no Brasil...(G7).

O envelhecimento da força de trabalho em enfermagem nos cenários estudados também é relatado nos discursos das gerentes, considerando a faixa etária dos servidores e a lentidão nos processos para abertura de concursos públicos. Nesse aspecto, elas correlacionam 0 contexto de adoecimento e incapacidade também às questões fisiológicas próprias do ciclo vital:

Junta a isso com o passar dos anos, né, a gente envelhece também. Então essas coisas vão somando e fatalmente esse profissional ao longo do tempo de exercício dele, ele vai adoecer também (G4).

Eu trabalho com um grupo de funcionários que na sua maioria tem mais de 50 anos... 55... 60.. 65... tem funcionário até de 70 anos, que já se aposentou e continua trabalhando. Isso contribui também...(G8).

(...)Porque o serviço público, eles foram tirando, as pessoas foram morrendo, as pessoas foram aposentando, as pessoas foram desligando (G3).

São pessoas já com bastante idade, tem pessoas acima de 60 anos que continuam trabalhando (G9). 
As gerentes ressaltam ainda que o processo de adoecimento e incapacidade nos trabalhadores de enfermagem tende a ser um ciclo vicioso, uma vez que trabalham com uma escala de trabalho extremamente reduzida em decorrência dos trabalhadores afastados. Dessa forma, o risco de trabalhadores que ainda estão saudáveis, sofrerem processos de desgastes em curto, médio ou longo prazo é muito elevado, conforme destacado a seguir:

Aí a carga de trabalho daquele que saiu ela é dividida com os que ficaram. Então daqui a uma semana... os que ficaram que começam a adoecer. Uma semana... um mês... é um processo. É cíclico, porque a coisa vai acontecendo ali... quando você vê... eu já tive época aqui de ficar com $70 \%$ dos profissionais da unidade afastados (G1).

(...)Eu tenho um corpo de enfermagem enxuto, muito enxuto. Eu não trabalho com gordura nenhuma. Então assim... quando dois ou três adoecem, que a gente não tem como repor, pensa... a gente vai sobrecarregar os que estão?, mais ainda do que já estão? (G4) .

5.1.1.2. A angústia para garantir a segurança do paciente e preservar a saúde dos trabalhadores de enfermagem

Os discursos evidenciam sentimentos de conflito, angústia, e impotência das gerentes de enfermagem, pelas questões relativas à qualidade do trabalho realizado e, especialmente pela segurança do cuidado prestado aos pacientes, conforme os trechos apresentados:

Olha, hoje a gente tem trabalhado muito em cima da questão da segurança do paciente, da segurança do profissional. Apesar da gente ter a tecnologia ali, 
entendeu, de ponta, né, a gente tem vários equipamentos que facilitam a assistência, a questão da assistência do ser humano para o ser humano é uma coisa que tem deixado muito a desejar no sentido de que todo esse estresse... você não tem mais tempo de estar ouvindo o paciente (G5).

Então às vezes eu fico até em um conflito. Por que?, porque a gente vê a coisa pelos dois lados, né. Você tem o lado do trabalhador, e tem o lado da instituição, do paciente, que a gente precisa atender também. Então a gente tem que equilibrar o tripé dos trabalhadores, do cliente e da instituição. Então todo mundo tem que ter as suas necessidades atendidas e precisamos produzir e alcançar os objetivos para cada uma dessas pontas aí desse tripé.(...)E eu fico um pouco preocupada (G1).

As gerentes de enfermagem referem sofrimento por perceberem que a força de trabalho está doente, entretanto, o processo de trabalho exige que a assistência ao paciente seja realizada:

É uma experiência bem sofrida. Porque assim... de um lado você tem o funcionário doente, o servidor doente, que apresenta a doença...Do outro lado você tem a assistência, você tem os pacientes que demandam... demandam trabalho. E quem perde com isso?, o paciente (G7).

Tem setores que você não tem como não fazer o teu trabalho bem feito porque o teu resultado é negativo. $E$ nós estamos aqui para que? Para que as pessoas saiam infelizes... ou uma coisa assim..(G8).

É, é todo um contexto. Então é isso... eu falo para você, como o gestor se sente... Se sente impotente, se 
sente impotente, angustiado, estressado... sabe?, porque ele está sabendo o que está acontecendo. Ele sabe que a sua equipe está adoecendo. E ele não sabe como resolver o problema (G3).

Então assim, a segurança... assim... o meu objetivo na verdade é fazer com que a assistência ela ocorra de uma forma mais segura tanto para o profissional quanto para o paciente (G5).

A realidade brasileira marcada pela crise na oferta dos serviços de saúde é destacada no trecho a seguir, onde a angústia é percebida na preocupação desta gerente de enfermagem em atender os pacientes, haja vista às longas distâncias percorridas, para receber um atendimento:

E é claro que a gente tem em primeiro lugar o paciente, porque a chegada do paciente aqui ela é muito complicada. Nós atendemos todo o interior do estado. Então nós temos tratamento fora de domicílio, temos pessoas que vem para cá só para conseguir a consulta, então você já pensou?, a pessoa pegar um barco, viajar não sei quantas horas, chegar aqui e - olha, sinto muito, faltou isso, não vai ter a cirurgia -, então a gente tenta fazer com que isso não aconteça (G6).

A angústia com a segurança do cuidado dispensado aos pacientes é percebida nas exemplificações de situações que podem colocar a assistência de enfermagem em risco, tendo em vista a gravidade do adoecimento mental dos trabalhadores de enfermagem que muitas vezes, pode ser negligenciada nos serviços de medicina do trabalho e nas instituições: 
O outro dia uma moça descompensou, aqui dentro desse hospital. Ela chegou para trabalhar, começa a dar aquela coisa doida... dando respostas sem lógica quando faz uma pergunta, agredindo às vezes o paciente, às vezes o funcionário, sem mais, sem menos... Aí vai, a coisa vai indo, você conversa - você não pode fazer isso, fulano está conversando com você...-, e vai indo... Um outro dia ela chegou aqui, brigou com a funcionária, brigou com a enfermeira $e$ se enfiou debaixo da mesa, falou - daqui eu não saio, ninguém me tira! (G1).

Isso me angustia na medida em que eu não tenho muito o que fazer sobre isso... Assim... o paciente está lá, tem que ser atendido essa é uma coisa que a gente se preocupa bastante... A pessoa não tem condição de trabalhar, está em uma condição precária, como é que vai cuidar bem?, não tem como... E assim, muita depressão... muito... (G9).

Os trechos a seguir evidenciam a preocupação e angústia das gerentes de enfermagem com a segurança dos pacientes, uma vez que já experienciaram ter na equipe trabalhadores de enfermagem que, frequentemente, abandonam o plantão e os pacientes que estão sob suas responsabilidades:

O dia que ela estava aqui, ela ia embora... não sei como ela conseguia sair daqui... 17.30, aí os colegas ficavam... eu não sei... ela fugia... aí falei - você não pode fazer isso, você está abandonando o seu paciente (...)e a questão ética... meu Deus...aí ela falava - não, é porque vai dando 17.30... e eu começo a pensar nos meus filhos em casa, o que estão fazendo, o que estão comendo, o que estão não sei o 
que... o que estão não sei o que... e de repente eu pego a minha bolsa e vou embora (...) (G1).

Ah, isso não tem como... essa pessoa que te falei é muito triste... A pessoa não veio a semana toda trabalhar e é readaptada já. Já não sei o que eu faço, já troquei de setor, já... não sei mais o que eu faço... já esgotei todos os meus... é uma preocupação muito grande minha... tanto é que a gente colocou uma outra pessoa, forte... então tem o forte para poder... porque Deus o livre (G7).

Algumas gerentes relatam erros na administração de medicamentos que, embora não tenham tido grave repercussão aos pacientes, podem estar relacionados ao contexto de adoecimento e incapacidade dos trabalhadores de enfermagem:

Dilataram o bebezinho e aí quando dilataram disseram para a mãe - olha, agora nós vamos levar para ver o olho da sua nenê -, aí a mãe começou a chorar - mas eu não vim aqui ver o olho, vim ver o ouvido -. Aí me chamaram (G6).

Um conflito comigo mesma de... de administrar, né, as duas situações.. Um dia uma moça chegou aqui, ela chorava, chorava, chorava, ela fez uma medicação errada em um paciente dentro da UTI (G1).

O trecho a seguir refere-se à angústia da gerente de enfermagem com a dependência química dos trabalhadores de enfermagem, seja pelo uso de medicamentos antidepressivos e outros depressores do sistema nervoso central: 
Então eu vejo que a maioria... puxa... sei lá... 50\% faz uso desse tipo de medicação, de antidepressivo (G8).

...gravíssimo! (...) o outro dia fui em um inquérito administrativo, servidor nosso, ele estava no banheiro, ele estava fazendo uso de Dolantina, a gerente dele, que pegou ele... entrou no banheiro, ele injetou e saiu sangue assim... Aí ela pegou a ampola e trouxe para mim, abriu um inquérito administrativo e tal (...)Sabe o que aconteceu com o processo?, morreu. E ele continua se drogando dentro do serviço. Já tiramos ele daqui, mas de dentro do hospital, não tem como...(G3).

Esse contexto de angústia vivenciado constantemente afeta a saúde das gerentes de enfermagem. Nos trechos que seguem, elas expressam que a situação de adoecimento e incapacidade dos trabalhadores de enfermagem também favorece o adoecimento dos gestores, entretanto, apontam a importância de não perderem a sensibilidade para as questões referentes aos trabalhadores, lembrando que embora o serviço necessite da força de trabalho, os trabalhadores demandam um olhar atento e de cuidado para evitar danos aos pacientes:

(...) A gente não pode perder essa sensibilidade de olhar o profissional. (...)E isso também a gente de certa forma adoece junto (G4).

... É uma pessoa que... olha, tem dia que eu fico assim... até choro...(G7).

Então eu fico no meio dessa coisa, de ter que cumprir, a responsabilidade de atender com segurança e qualidade e de responsabilizar pela saúde dos trabalhadores que estão no trabalho (G1). 
Você está ali, naquela... participando no dia a dia. Aí você vê e você pega o prontuário e começa a ler as histórias... gente... aquilo ali você tem que tomar muito cuidado senão você adoece junto (...)isso não me faz bem (G3).

Então assim, é difícil por um lado, o lado administrativo, gerencial, aquela coisa mesma assim do papel, de você estar contando. Por outro lado, você tem que ser... você tem que ver que tem uma pessoa. Tem um ser humano. (G2).

É também a questão da empatia, de você se colocar no lugar do outro, no sofrimento do outro.(...) Imagine você tendo que viver isso, enquanto profissional, o sofrimento do outro, se colocar no lugar do outro, presenciar o sofrimento do outro (G5).

O relato a seguir evidencia que as gerentes dos cenários estudados reconhecem a sua responsabilidade ético-legal no gerenciamento de recursos humanos e na assistência prestada aos pacientes:

A responsabilidade do adoecimento do servidor e se ele continuar no trabalho eu que respondo por ele, porque tenho responsabilidade civil, etc e tal... a responsabilidade pelo não atendimento do paciente ou do atendimento inadequado é minha também, eu respondo por isso. E a responsabilidade de manter a instituição, o conceito da instituição, Aí eu fico no meio. O servidor está doente mas eu preciso dele. (...)e como que é isso para você, você... daí enfermeira, pessoa, aquilo que você estudou... viver essa situação e ser uma pessoa que é responsável por essa... de dar uma solução. Como que é para você, assim...é difícil, é difícil. ...e o risco... meus 
princípios éticos... meu conhecimento. E aí, o que a gente faz? (G1).

Apesar da preocupação com a assistência de enfermagem e a segurança dos pacientes, as gerentes reconhecem que muitas exigências do processo de trabalho são humanamente impossíveis de serem atendidas:

Porque é impossível, humanamente impossível você trabalhar em uma enfermaria, tipo, uma ortopedia, com 22 leitos e com três profissionais. Onde eu tenho 60... 70\% dos pacientes acamados, tendo que dar banho no leito.... então amanhã ele vai estar acabado, e isso são todos os dias (G4).

E aí você trabalha na área da saúde, você está cuidando de pessoas que estão precisando de cuidado e você está mais doente do que aquela pessoa... que internou...e fica inviável (G8).

As empresas pensam em custos, então diminui $o$ quantitativo de profissionais atuando, você tem os profissionais doentes, que acabam sobrecarregando os colegas na assistência. É difícil, é, porque você tem uma escala a cumprir, você tem um serviço para tocar, (...) não é uma coisa fácil, não é uma coisa fácil.... porque é muito difícil...não é fácil não (G5).

Porque não tem lógica de uma pessoa estar lá, enfermeiro, com seis técnicos de enfermagem para cuidar de 80 pessoas! em um corredor, cheio de macas... não pode...(G2).

(...) eu precisava de ter mínimo de 6 pessoas para atender a clínica com 42 leitos. Assim... essa é a medida que eu te falo...(G1). 
A problemática do presenteísmo também é notada pelas gerentes como um fator a ser considerado na qualidade da assistência prestada. Nos discursos, as gerentes relatam que, embora muitas vezes o quadro de pessoal em termos quantitativos esteja adequado, em termos qualitativos, esses trabalhadores não correspondem, uma vez que grande parte deles apresenta restrição física e/ ou mental, podendo comprometer a organização e a qualidade final do trabalho:

Então, é uma coisa bastante difícil e angustiante, porque você está no meio do caminho entre dois lados (...) é o presenteísmo que a gente chama (...) como número...mas em qualitativo... (G4).

E aí essas pessoas contam como... da enfermagem...contam lá... consta, você tem tantos técnicos de enfermagem, você tem tantos enfermeiros...(...) (G2).

(...) quando você se depara com que... o humano ali, os recursos humanos ele não está correspondendo...à necessidade do serviço (G8).

A angústia também é expressa pela escassez de políticas institucionais direcionadas à gestão de pessoas, considerando o atual cenário de adoecimento e incapacidade dos trabalhadores de enfermagem, especialmente para a reposição de pessoal, tanto em relação aos trabalhadores afastados como aos aposentados:

Me angustia na medida em que eu não tenho muito o que fazer sobre isso... Assim... o paciente está lá, tem que ser atendido... eh... a possibilidade de virem outras pessoas é muito pequena, praticamente não tem essa possibilidade... porque não tem concurso, não pode abrir concurso... (G9). 
E aí esses que estão na coordenação eles não são repostos para o cuidado... porque aqui a gente... nós somos uma instituição pública (G5).

Porque as pessoas realmente estão adoecendo. Aí eu fico pensando assim, meu Deus, como você fica como gestor?, um serviço público que concurso não tem.(...) (G3).

Está todo mundo angustiado... é muita pressão e... sistema... o sistema administrativo nosso não é bom, né, a parte de recursos humanos, que eu acho que é uma coisa essencial dentro de uma instituição... aqui é muito fraco, aqui é fraquíssima... entendeu?, ela não existe... (G8).

A ausência de políticas destinadas à saúde dos trabalhadores, com vistas à notificação dos agravos, ao tratamento adequado do trabalhador, assim como medidas de promoção e prevenção, também é enfatizada pelas gerentes de enfermagem:

(...) sai com uma licença médica e pronto. Aí o que acontece?, não é feito um trabalho com ele para ver se é a ocupação dele que está provocando isso, para estar tirando ele dessa ocupação (...) como é que uma pessoa que trabalha em uma instituição ela falta mais do $50 \%$ durante um ano e não é feito nada?! (G7)

Então é desse jeito aí, nós temos uma dificuldade enorme, enorme, e eu te falo assim, essa inexistência de uma política de recursos humanos efetiva para promover a saúde do trabalhador e prevenir doenças. (G1) 
Então, assim, a coisa é séria (...)um hospital dessa natureza, enorme, um hospital escola, grande porte... gente... não é feito nada hoje aqui na instituição (...) visando a saúde do trabalhador... (G3).

Somado às cobranças pela garantia da qualidade da assistência de enfermagem e segurança do paciente, as gerentes descrevem a cobrança pelas metas e produtividade:

A gente... mesmo às vezes não sendo função nossa, corre atrás de material, de pessoal, para que o serviço ande. Por que?, o hospital é 100\% SUS, então se a gente não produzir o hospital não tem como... se sustentar (G6).

Sinto porque há uma cobrança, você está em um hospital, você está atendendo pessoas, existe uma fila grande e você tem que... ter um trabalho de qualidade e produtividade também.(G8)

Equipe muito sobrecarregada... E assim, e não é aqui (...) não tem, não tem, porque todo o tempo eles estão te cobrando produção, produção, produção. (G3)

\subsubsection{O prazer no processo de trabalho gerencial}

Ao analisar dos discursos foi possível perceber que embora desgastante, repleto de dificuldades e angústias, o processo de trabalho das gerentes de enfermagem também faz emergir sentimentos de prazer.

No contexto de adoecimento e incapacidade da força de trabalho em enfermagem, as gerentes têm a oportunidade de se aproximarem da realidade dos trabalhadores doentes. Essa proximidade com os 
trabalhadores, o acolhimento às suas demandas e as tentativas de reorganização e reinserção dos mesmos nos postos ao trabalho são reconhecidos e valorizados pelos trabalhadores de enfermagem. Observa-se que as gerentes de enfermagem do estudo manifestam sentimentos de satisfação pessoal pela especificidade do trabalho gerencial e pelo reconhecimento do trabalho realizado junto à equipe:

É que as pessoas me procuram... As pessoas chegam e me procuram mesmo, então eu me sinto realizada profissionalmente como pessoa... Então assim... aqui eu tenho um índice de aprovação na questão de gestora que é incrível!!!! G2

Então assim, ele é um trabalho desgastante, mas para mim prazeroso, porque eu já estou envolvida nessa parte administrativa, nessa parte gerencial (G6).

Eu gosto muito do que eu faço... Eu gosto muito, sempre procuro me atualizar dentro do que é possível, e gosto, realmente gosto, com outra profissão acho que nunca me imaginaria (G8).

Esse olhar atento das gerentes ao reconhecer as necessidades e as dificuldades dos trabalhadores, abandonando preconceitos configura uma evolução nos processos gerenciais além de representar um avanço significativo e necessário na saúde do trabalhador.

As gerentes relatam com satisfação que possuem um papel fundamental no reconhecimento da doença e no seu encaminhamento, o que representa um ganho para o trabalhador que vivencia um problema de saúde e geralmente se sente culpado por tal situação:

É que para mim o adoecimento eu tenho que observar não só do técnico de enfermagem mas dos 
coordenadores... Tem uns aqui que chegam e tem dia que eu falo - olha, hoje vai embora e pode ficar uns dias sem aparecer por aqui. Vai descansar essa cabeça -, porque ninguém dá conta disso daqui. - nós aqui não estamos te suportando do jeito que você está. Então, vamos descansar um pouco para você voltar bem? -, às vezes a pessoa sai, fica 4 dias, descansa, volta... não posso deixar, de jeito nenhum (...) vamos primeiro procurar um médico, vamos procurar um psicólogo, vamos tratar, você não tem condição de voltar" (G1).

Eu me sinto muito bem, eu sinto compensada assim, como pessoa, como profissional(...) é um laço mesmo, um vínculo, né...é assim... eu já cheguei para uma pessoa... e chamei pelo nome, falou - você sabe o meu nome- (...) mas eu não estou nem de crachá para você olhar, mas eu sei o seu nome(...) Ela me abraçou (...)Tem que haver essa... essa questão do reconhecimento (G2).

O reconhecimento e a satisfação do grupo emergem também da iniciativa e prontidão das gerentes em atender às necessidades dos trabalhadores de enfermagem conforme elas relatam:

Tem a parte boa porque eh (...) na realidade a gente faz isso muito em parceria com o profissional (...)porque tem limitação funcional, olha, chama ele, conversa, e a gente chega a um acordo...a gente atende, dentro do possível, um pedido dele (G4).

E assim... a gente procurou resgatar isso, trazer as pessoas para o lugar que gostam de trabalhar (G7). 
A análise dos discursos também possibilitou a percepção de que as gerentes sentem-se realizadas no trabalho por encorajarem os trabalhadores de enfermagem que possuem restrição, estimulando-os a continuarem produtivos, além de investirem em um trabalho com o grupo que receberá o trabalhador com incapacidade a fim de minimizar os conflitos tão comuns neste processo:

Esse momento da doença é um momento assim que eu mostro para ele que ele tem capacidade de recuperar(...) eu me sinto bem ...eu gosto disso (G2).

(...) Se coloquem no lugar desta pessoa, sozinha, que está aqui, neste grupo de 20 -, então... - percebam ali como é, coloquem um espelho -, aí já foi quebrando, alguns já foram quebrando as arestas...isso é bom (risada) (G4).

Amanhã pode ser você, então se hoje o colega está precisando, ele adoeceu, hoje a gente vai cobrir. Se amanhã você precisar (G6).

Aí fui, fui, fui... essa moça vinha aqui, ia embora, chorava... ia embora, voltava, conversava de novo... meio fazendo uma terapia comigo. Restou que, depois de uns dois ou três meses de conversa... ela pediu demissão do emprego dela, da urgência emergência daqui e ficou só em um e fazendo a faculdade. (...)Então agora ela está estudando, está trabalhando aqui... ela não dormia na casa dela nenhum dia no mês! Aí ela começou aqui comigo toda essa mudança (G1).

A sensação de contribuir para a manutenção de um sistema de público de saúde que atenda às necessidades da população, também representa uma fonte de prazer no trabalho, segundo o relato das gerentes: 
Tem, tem os ganhos (...) é prazeroso, tem a parte boa, né, não é só a parte ruim...tem a parte boa... A gente se sente viva, a gente se sente ajudando, colaborando com o sistema, então isso é bacana (G4).

Olha, eu estou assim... eu tenho pessoas, quando a gente conversa, falam - continua, continua, que a gente vai fazer -. E eu fico animada, eu fico animada...com o serviço, entendeu? é todo um envolvimento... porque você se envolveu, se envolveu, sabe? (ri) (G3).

Já faz parte, então a gente se envolve com essa questão do funcionamento, do paciente.. você está fazendo... é para a instituição... pelo paciente....(G6).

5.1.1.4. A organização do trabalho no contexto das incapacidades para o trabalho

Diante do contexto apresentado, as gerentes de enfermagem necessitam organizar a dinâmica de trabalho, a fim de minimizar o desgaste na equipe e garantir uma assistência de enfermagem segura e qualificada. Os discursos coletados evidenciam algumas estratégias empregadas para a organização do processo de trabalho, como a utilização de planilhas e dados estatísticos acerca da complexidade dos pacientes e limitação dos trabalhadores de enfermagem, conforme vemos:

Nós temos uma planilha, trabalhamos com ela, com tudo, o que o paciente está tomando, o que faz... Então a gente precisa desocupar um leito aqui para receber um outro, a gente discute, faz reunião clínica para definir o que pode ficar junto, o que não pode, onde põe... Se não puder, se tiver que ficar sozinho nós damos um jeito de tirar os outros pacientes e deixar... Então é um trabalho muito bem feito do ponto de vista técnico (G1). 
E aí a gente elaborou um instrumento, elaborou uma estatística de trabalho que eu disse - olha, eu não posso chegar lá na minha gerente e disser: 'preciso pessoal para mim, o pessoal está todo mundo desgastado... isso ela já sabe, isso é o discurso - uma coisa é o discurso, outra é você provar... (G7).

A transferência de unidade e/ou setor representa uma das estratégias mais utilizadas para organizar o trabalho, entretanto, as gerentes destacam o cuidado de não tornarem determinadas áreas, depósitos de trabalhadores com restrições:

Então aí grande parte dos profissionais tem limitação funcional. Então eles são quase que drenados para lá, porque a gente sabe que não vai ter tanto...peso... tanta manipulação de paciente, virar de um lado, virar do outro, colocar em cadeira de rodas... e levar...Então a gente faz essas...adequações...mas lógico que eu tenho uma limitação, porque não posso pôr todo mundo lá. É um quebra cabeças...(G4)

Tem aquelas pessoas que não podem... chega $o$ relatório do médico e está aqui, que não pode subir nem descer escadas, não pode ficar em pé, não pode levantar o braço, não pode puxar, não pode empurrar. Aí eu falo... aí eu penso, vou pôr onde essa pessoa? Aí você... determinados locais começam a virar depósitos de pessoas doentes(...) Porque se a gente não trabalhar de uma forma que permita que as coisas fluam, as coisas emperram...(G1).

Tem uns que chegam que não podem pegar dois quilos... não podem pegar nem dois quilos de peso, não podem fazer movimentos repetitivos, não pode ficar muito tempo em pé, não pode ficar muito tempo 
sentado. Aí - achei um lugar para você, você vai ter que andar um pouquinho, mas vai carregar só os pedidos do paciente na mão, não pesa dois quilos (G2).

Para organizar a dinâmica de trabalho, as gerentes precisam conhecer as características das clínicas, as atividades que são desempenhadas em cada setor além de desenvolverem um olhar cuidadoso às limitações apresentadas pelos trabalhadores de enfermagem, conforme evidenciado nos trechos a seguir:

Quando chegou a menina - oh, o doutor mandou uma funcionária aqui... ela não pode mais ficar na enfermagem, tem que fazer a mudança de lotação -, precisa, vai ter que mudar de lotação mesmo, ela não dá conta, ela não dá conta (G3).

É feito reunião com a chefia, para conversar se é possível manter esse funcionário lá com essa restrição que ele tem...(G9).

Então assim, é um quebra cabeça. Tem que juntar pecinhas e nem sempre é fácil. então a gente vai pisando... andando entre cristais...fazendo uma mágica. A gente tem conseguido, né, com muitas dificuldades, e estamos sobrevivendo (G4).

Esse olhar cuidadoso direcionado à limitação apresentada pelo trabalhador, possibilita que as gerentes de enfermagem tenham condição de avaliar se o trabalhador ainda pode permanecer na assistência direta ao paciente. Há situações em que os trabalhadores são alocados em atividades não relacionadas à assistência direta ao paciente, conforme destacado a seguir: 
Mas a gente tem procurado inclusive direcionar para atividades que não sejam de assistência direta ao paciente, para que a gente possa estar ajudando esse profissional (...) mas que a gente tem que ter muito cuidado no dia a dia para que essa doença não venha a se agravar (G5).

Então, tem que 'readequar'. E eu vou procurar estar readaptando em um local onde ela possa estar indiretamente contribuindo para a assistência, né. Se você for ver institucionalmente, às vezes é ruim. Porque, por exemplo, quantas técnicas de enfermagem, enfermeiro que eu estou... é desvio de função?, pode ser, mas eu tenho que readaptá-las (G2).

Mas normalmente a gente consegue, né, fazer... como é uma unidade, né, lá são vários serviços... são só dois de assistência, mas tem laboratório, tem ambulatório... tem outras coisas (G9).

Diante da complexidade da situação, caracterizada por escassez de recursos humanos em termos quantitativos e qualitativos, outra estratégia empregada pelas gerentes de enfermagem nos serviços, consiste no fechamento de leitos temporariamente, a fim de garantir a qualidade assistencial, a segurança do paciente, além de reduzir o desgaste dos trabalhadores de enfermagem, conforme os trechos apresentados:

A gente tem que estar falando...tem muitos leitos fechados por causa do pessoal (G2).

Tem horas que chega no fim do túnel e a gente não tem como resolver o problema, então aí a gente vai para instancias maiores. Semana passada mesmo a gente se deparou com uma situação dessas, então a gente tem que diminuir os leitos, provisoriamente (G4). 
Eu estou com 17 leitos fechados no pronto socorro, 32 na clínica cirúrgica e vou fechar mais... é a mesma coisa que falar - vamos fechar a residência -. Aí tem... você tem que pensar nisso. Mas você vai deixar esses pacientes lá... serem mal atendidos? (G1).

Por exemplo... eventualmente diminuir leitos, o hospital tem 530 leitos... sei lá... 500 e tantos leitos... estamos trabalhando com uma média de 230 ... olha o absurdo que é... (G9).

As gerentes relatam também que muitas ausências não são previstas e nem tampouco avisadas com antecedência. Nesse sentido, elas necessitam redistribuir os trabalhadores nas diversas unidades de forma repentina, para priorizar o cuidado aos pacientes:

Então, cada vez que eu recebo uma mensagem que eu não vou vir -, eu já chegou aqui... eu já venho dirigindo pensando... - eu vou trocar ali, vou trocar aqui... -, já chego assim (G6).

A gente tem que redistribuir e priorizar a assistência (G7).

Mas para isso a gente precisa cobrir a unidade original, não posso tirar ela e simplesmente... bota cá, né?, e o buraco aqui? resolve um problema e não resolve $o$ outro... então... tem que buscar alternativas para que a gente possa fazer as duas coisas (G4).

As readequações e redistribuições muitas vezes geram desconforto na equipe de enfermagem, nos trechos a seguir, as gerentes evidenciam a necessidade de atentarem para esta questão e organizam 
reuniões periódicas para discutir e buscar soluções para esses problemas tão frequentes no processo de trabalho:

Então... um acaba poupando o outro. Já é uma coisa estabelecida na equipe, então não tem muito problema. Mas... assim... periodicamente... isso acaba incomodando um, e aí a gente tem que fazer reunião para... pactuar novas coisas... então (...) Porque se acham prejudicadas, porque estão trabalhando muito,...(G9).

Aí você recebe a resposta dessas pessoas em cima de você enquanto gerente. Te cobrando, - puxa, não tem condições -, e isso traz um sofrimento muito grande muitas vezes... de funcionários até que chegam a chorar... entendeu?, há um stress muito grande de toda a equipe (G7).

Às vezes tem um funcionário que tem muita licença médica... não trabalha, e o grupo está achando que ele está com 'invenção', que aquilo não é verdadeiro, eu vou lá conversar (G1).

Porque quando você pede para substituir uma vez, tudo bem. Mas quando você percebe que você está substituindo sempre o seu colega, você começa a questionar - puxa, por que?, é melhor trocar o funcionário de setor, porque só faz faltar (G6).

A ação de gerenciar a força de trabalho incapacitada, fundamentou-se na reflexão da vivência dessas enfermeiras no processo de trabalho (motivos porque), marcado pela percepção de um cenário preocupante na enfermagem brasileira. Diante da problemática do adoecimento e incapacidade nos trabalhadores de enfermagem, evidenciase uma projeção representada pela intencionalidade das ações das gerentes 
de enfermagem, traduzida nas expectativas na gestão de pessoas (motivos para), categoria que será apresentada a seguir.

\subsubsection{A expectativa para a gestão de pessoas}

A partir da vivência dos sujeitos emerge a necessidade de olhar para o futuro e vislumbrar uma infinidade de possibilidades para a mudança. A expectativa para a gestão de pessoas surgem da ação de gerenciar a força de trabalho incapacitada e a partir da vivência dos gerentes de enfermagem neste contexto social, enriquecida com a sedimentação dos conhecimentos, traduz-se na intencionalidade de ações.

A expectativa para a gestão de pessoas abarcam a construção de uma gestão mais participativa, o investimento em políticas de recursos humanos em saúde e o delineamento de novos caminhos na vida pessoal e profissional.

\subsubsection{Construção de uma gestão mais participativa}

Embora a realidade descrita tenha evidenciado que as gerentes já se reconheçam fundamentais no processo gerencial, elas reforçam que a gestão participativa ainda precisa ser aprimorada, com o intuito de agregar as pessoas, compondo um coletivo que reconheça a problemática em questão, minimizando os conflitos existentes para construção de propostas para melhoria da situação atual, conforme destacado a seguir:

Recursos humanos tem que ser assim, gestão de pessoas tem que ser assim, para estar minimizando tudo isso... (G2). 
Eu acredito que as coisas têm que ser... as decisões... tem que ser compartilhadas. Já foi o tempo que as pessoas mandavam e o resto...obedecia...(G9).

Mas eu acho que também tem um pouco da questão da gestão um pouco mais participativa...(G1).

Então você tem que mostrar que trabalho é trabalho, e que a gente tem que estar aqui e isso a gente tenta fazer assim... lado a lado (G6).

Nesse contexto, as gerentes esperam desenvolver cada vez mais a escuta e o acolhimento aos trabalhadores, a fim de, possibilitar um melhor fluxo na comunicação, conforme os trechos:

Então assim, é procurar trabalhar a unidade, por unidade, procurar ouvir a equipe, fazendo reuniões, procurar fazer com que a comunicação seja o mais clara possivel (G5).

Acolher é essencial...(...). a questão de você ouvir a pessoa, você tem que ouvir, tá?(G2).

Então acho que essa coisa da gente sentar junto e explicar......com os trabalhadores, isso é muito legal (G4).

Dar uma oportunidade dele chegar e falar - olha, estou de saco cheio, estou cansado... isso e aquilo.......) um espaço. Então acho que ouvir ele é muito importante. Por mais que ele só fale coisas que você sabe que ele não está com a razão...(G8).

Ainda em relação ao acolhimento dos trabalhadores de enfermagem, as gerentes descrevem a necessidade de se criar um 
movimento institucional de "se colocar no lugar do outro", haja vista, o sofrimento dos trabalhadores que adoecem e ficam incapacitados, temporária ou permanentemente, enfrentado nesse processo:

E a gente também está nesse contexto. Então é muito comum e fácil de entender que a gente adoece também (G4).

É também a questão da empatia, de você se colocar no lugar do outro, no sofrimento do outro. Só por aí você já não... é diferente de quem trabalha em outras instancias (G5).

Eu tenho que ver... se você está realmente preocupada, está no lugar certo de fazer as coisas (G3).

Aí a gente... eu... acho que esse exercício de às vezes você se colocar no lugar do outro é muito importante aqui para nós (G1).

Os discursos revelam que ao realizar uma gestão mais participativa, as gerentes esperam aprimorar a habilidade para cuidar da força de trabalho em enfermagem, apoiando e resgatando a sua capacidade de produzir e agregar nos serviços:

Cuidar deles um pouco também -... porque essa também é a nossa função, cuidar de quem está cuidando... que é a força de trabalho, né?(G8).

Manter as pessoas nesse tipo de atividade, recuperar a saúde delas e produzir alguma coisa (G1).

Eu acho que assim... nesse ponto talvez a gente... quer dizer... o que a gente pode fazer?...tem que dar 
um apoio para o enfermeiro, para que não chegue a adoecer...(G9).

A confiança também aparece nos discursos como algo fundamental para transformar o cotidiano, onde as gerentes acreditam que na medida em que a equipe confia na gestão, os processos tornam-se mais tranquilos pela transparência nas decisões, como pode ser observado:

A gente sabe, né, quando a gente confia, confia naquela gestão de que a coisa está sendo feita da melhor forma, tentando ser feita da melhor forma, isso meio que acalma, né, trabalha com mais tranquilidade, do que você viver apreensivo, que tudo pode acontecer (...) isso é muito importante, né... em uma gestão (G4).

(...)dar tranquilidade a minha equipe...porque o que chega aqui para a coordenação a gente não deixa passar em branco. A gente sempre toma uma atitude (G5).

Os discursos revelam que a valorização dos trabalhadores é descrita pelas gerentes de todos os cenários, como um elemento essencial na gestão de pessoas, do ponto de vista da valorização do ser humano e de suas potencialidades, conforme observa-se nos trechos a seguir:

(...)espero colocá-los para trabalhar onde realmente eles gostam de trabalhar, você está entendendo?, Sabe, porque eu acho que o ser humano é recuperável, acho que precisa desse apoio, acho que precisa de sentir-se valorizado, acho que ele precisa se sentir gente. - Olha... tem gente que se preocupa comigo, tem gente que acredita em mim(...)você tem que tentar o máximo possível mostrar para ele que ele tem valor, que a gente precisa dele aqui, certo?, a 
gente tem que fazer esse tipo de trabalho, - nós precisamos de você (G2).

Resgatar isso... resgate da auto estima (...) trazer as pessoas para o lugar que gostam de trabalhar (G7).

Conversar com alguns funcionários (...) Eu sinto assim que... da importância dele no trabalho, as dificuldades que a gente sentiu na ausência dele... para que ele sinta que ele faz parte! Ele faz parte daquele grupo... e ele faz diferença (G8).

Tratando-se da construção de uma gestão mais participativa, os discursos das gerente de enfermagem evidenciam a importância de se resgatar o valor ético profissional, considerando as questões de compromisso e responsabilidade, tendo em vista a fragilidade que esses princípios tem se apresentado no cotidiano de trabalho:

...reconstruir o valor ético da profissão em relação ao que é esse compromisso de estar cuidando do paciente. Porque eu acho que essas questões também perpassam por uma situação de abandono que a gente vê. Se alguém está, tudo bem, se é uma questão mental e a pessoa está no shopping passeando é terapêutica, ela está se distraindo, sim. Mas se é uma questão que a pessoa não vem porque não vem... porque aqui é o dia que ela vai descansar, sabendo que uma clínica está com 46... né... é demais! (G1).

Resgatar o compromisso, o valor ao trabalho, puxa, além de eu fazer o que eu gosto eu tenho estabilidade -, acho que isso é uma coisa... mas não sei... o pensamento atual não é... Acho que as pessoas no passado têm mais esse conceito, - gosto do meu 
trabalho, sei que amanhã ninguém vai tirar o meu trabalho -, e essas coisas assim (G8).

Eu fico olhando assim... eu fico pensando, onde é que está o compromisso. Então isso tinha que ser amarrado de alguma forma... sabe... de... não sei te $\operatorname{dizer...(G7).~}$

5.1.2.2 Investimento em políticas de recursos humanos em saúde

As gerentes de todos os cenários brasileiros referem a necessidade de investimento em políticas de recursos humanos em saúde. Esse investimento aparece em termos quantitativos, com a sensibilização de órgãos e entidades de classe, e do governo para a abertura de concursos e contratação de pessoal de enfermagem:

Eu tinha muita vontade de ser presidente do COREN aqui, era um sonho meu, porque eu vejo tanta coisa que precisa... às vezes eles falam assim - se não for Alexandrina para peitar isso aí (...) Então, eu tinha vontade assim(...)para realmente divulgar a enfermagem, de ir lá... fazer acontecer (...) Por exemplo, Mais Médicos, esse acordo do governo, o médico não trabalha sem enfermagem. Por que só 'mais médicos'?, quem... o que as instituições, as entidades de enfermagem fizeram para mostrar que o médico... não trabalha sem a enfermagem...(G1).

A gente trabalhar em cima disso aí, da diretoria, dos órgãos maiores, porque não depende da gente. Depende de instâncias maiores. Então eu preciso sensibilizar essas instancias, mostrando, né, com fatos, e esta instancia também estar sensibilizada na linha de correr atrás disso (G4). 
Eu acho que o governo tem que olhar diferente, diferente para as pessoas que trabalham nesse setor. E investir... porque trabalhar na área de saúde não é uma coisa fácil... (G8)

Ah, porque assim... daqui a um pouco o pessoal vai estar tudo... assim... 80\% das pessoas vão estar com sei lá... 60 anos... estão se aposentando...e o que o hospital vai fazer com isso? não está fazendo nada porque não tem concurso, não pode abrir concurso... Então nós estamos em compasso de espera, mas... em 2007... que foi um dos últimos... foi o penúltimo concurso... que teve... então tem muita gente que já está em condições de se aposentar, e muita gente quer se aposentar mesmo. Então, o que vai acontecer?, não sei... assim... essa é uma coisa... o futuro (G9).

A melhoria das condições de trabalho não se refere apenas ao quantitativo de pessoal, mas também às condições de trabalho, considerando a estrutura física, os equipamentos e os materiais, com vistas à assistência qualificada aos pacientes, conforme apresentado nos trechos:

Ah... eu queria tanto ver a enfermagem, ver esta instituição... trabalhando com condições mínimas... né... de trabalho, de material, de equipamento, de pessoal, onde a gente pudesse, de fato, fazer uma assistência de qualidade, tanto para o profissional quanto para o paciente. Nós não vamos chegar em um patamar maravilhoso, mas se eu conseguir enxergar uma enfermagem trabalhando com mais condições de recursos humanos e recursos materiais... isso já vai fazer uma diferença grande. Isso espero (G4). 
Investir muito, mas muito mesmo em recursos humanos, em todos os sentidos. Tanto as pessoas que vão cuidar, os trabalhadores, como o número... pelo menos assim... não digo que... mas o mínimo... mínimo... exigido, para que se possa dar uma assistência de qualidade para as pessoas que vêm até aqui (...) é ter uma política de $\mathrm{RH}$ em todos os sentidos, sabe?, qualidade devida dentro do trabalho. Esse é um ponto fundamental (G8).

Proteger o trabalhador, eu acho que sem... o trabalhador saudável ele é necessário para a gente, principalmente para a nossa atividade de trabalho. Como você cuida de um se você não está bem, né, se você está doente (...)(G1).

Os trechos a seguir evidenciam que as gerentes gostariam de poder deixar um legado, no sentido de construir melhores condições de trabalho, seja em recursos materiais, físicos e de pessoas. Neste sentido, destacam a importância da melhoria da assistência à saúde dos trabalhadores, contando com uma equipe multiprofissional para atender as suas demandas :

Porque eu queria... o meu sonho era ter uma sala... uma sala laboral assim... onde eu tivesse... como é um hospital escola, tivesse o fisioterapeuta, eu tivesse o terapeuta ocupacional, porque tem o curso dentro da universidade, eu tivesse professor de educação física, tá?, eu tivesse um psicólogo. Tivesse... eh... mesas... as macas, tivesse aquelas cadeiras de descanso. Queria uma TV e queria aquelas cadeiras de massagem (...) estou querendo deixar um legado, se eu deixar só o escrito, isso morre, esses dados 
morrem. Se não tiver uma pessoa ali, presente (bate com a mão), para poder cobrar, vai morrer (G3).

Precisamos implementar as políticas de recursos humanos...um programa de saúde do trabalhador um pouco mais elaborado que a proposta do governo. Então é uma série de coisas que a gente precisa pensar e continuar trabalhando e trabalhando dando passos, né, à frente (G1).

Então, foi o que eu falei, é necessário que a instituição estabeleça uma divisão de assistência ao servidor, com médico, com enfermeiro do trabalho, com assistente social, com fisioterapeuta... O fisioterapeuta aqui dentro, para trabalhar... porque muitas vezes essas pessoas não tem plano de saúde. Não tem como fazer uma fisioterapia. Põe um fisioterapeuta para atender!, faz, atende o... faz o trabalho preventivo... nas pessoas, vai identificar, vai fazendo um mapa de risco das coisas...(G7).

Ao projetar o investimento em recursos humanos, as gerentes apontam os treinamentos como uma estratégia para qualificar a equipe de enfermagem e consequentemente melhorar a dinâmica de trabalho:

O que a gente pode fazer para trabalhar isso?, trabalhar em cima de treinamento, utilizar de ferramentas para que esses funcionários não fiquem sobrecarregados na assistência (G5).

Rever determinados remanejamentos, no sentido de que, por exemplo, funcionário que já estava há 20 anos no pronto socorro... mecanicamente... ele estava no pronto socorro. Já acostumou a aquela rotina...ele não vê mais outro desafio. Não tem mais outra 
novidade, ele não tem assim... parece que ele não quer aprender mais outra coisa... a não ser aquilo ali. E ficou muito limitado. Aquela redoma. ... valorizar profissionalmente com treinamento, com recursos e tudo mais (...)Aí, nesse ínterim, o que acontece?, qualifica a pessoa, qualifica a assistência (G2).

Tirar um pouquinho para assistir uma palestra, você não tem... porque você... vai fechar uma sala?, porque o funcionário vai assistir algo que é importante para ele, né? (G8).

O investimento de recursos humanos em saúde também deve considerar um plano de carreira com melhores salários para que os trabalhadores não necessitem acumular mais de um vínculo empregatício, o que hoje representa um sério problema no adoecimento da força de trabalho em enfermagem. As gerentes destacam a questão da luta a partir dos sindicatos e da própria categoria para transformar o contexto atual, conforme os trechos a seguir:

Lutar dentro das minhas condições, enquanto... atuando dentro do sindicato mesmo, para que a gente consiga uma carga de trabalho alinhada a planos de cargos e salários, para que a gente possa estar tendo tranquilidade para trabalhar. Então assim, acho que é uma luta da categoria mesmo, e que eu acho que eu tenho que estar inserida como gestora (G5).

Nós temos um campo, aqui nós temos um campo aqui que está precisando simplesmente semear para colher, o reconhecimento (...) Nós somos o maior grupo, talvez vocês não saibam o quanto nós somos fortes, nós somos o maior grupo -. Então a gente tem que ter essa união para a gente conseguir. Não dá 
para trabalhar desunido. Já tem a divisão técnica, dentro da equipe... (G2).

Lutar para fortalecer a direção, fortalecer as enfermeiras...nós como equipe, a enfermagem como um todo...(G9).

Então assim, puxa vida. A gente devia ser melhor tratado um pouquinho. (risada). Sempre fico pensando, às vezes fico assistindo TV Senado, né, aí eu penso -nossa categoria é uma categoria que ela precisava ser vista com mais carinho pelos governantes. Carinho, diga-se: essa sensibilidade, a gente trabalha com gente doente. A gente trabalha com a morte o tempo inteiro ao nosso lado (G4).

Ao projetar uma ação com vistas à transformação do contexto de incapacidade dos trabalhadores de enfermagem, as gerentes consideram relevante a melhoria dos processos de notificação dos agravos, uma vez que ao se obter dados reais acerca do adoecimento, torna-se mais fácil pensar em estratégias de intervenção. Nesse aspecto, os trechos a seguir evidenciam a expectativa das gerentes em relação à notificação dos agravos, não apenas em termos numéricos como na descrição de sua natureza:

Mas eu queria saber qual era a doença... e principalmente quando eu vim trabalhar com RH. Falei, - gente, tenho que saber o que está adoecendo esse pessoal e o que o RH pode fazer para estar, pelo menos assim, tentando amenizar a situação (G3).

Mas a gente tem que entender por que aquele funcionário está adoecendo tanto, o que está acontecendo com ele, (G5). 
Então, por isso que eu queria fazer essa pesquisa que estou te falando, para ver a realidade nossa aqui, por que as pessoas estão adoecendo. (...) 'quanti'... ela só vai dizer o tanto que teve... E não é isso. Aí vamos ver o que vai dar. (G1).

A necessidade de ferramentas institucionais para realizar a vigilância à saúde dos trabalhadores de enfermagem é destacada pelas gerentes, conforme vemos:

A gente sabe de alguns afastamentos inclusive, por conta do adoecimento, mas em termos de estatísticas, de números, eu não tenho (G5).

A gente não tem estudos hoje na instituição... Então, na verdade, a instituição não tem nada de recursos para mensurar isso (G3).

Porque assim... para você fazer uma gestão você tem que ter planejamento, então, espero ter dados concretos para fazer o diagnóstico da situação, fazer um plano de ação, e poder trabalhar...(G7).

\subsubsection{Delineamento de novos caminhos}

A partir dos discursos, observa-se que diante dos anos de trabalho e do desgaste por conta do contexto enfrentado na ação de gerenciar a força de trabalho incapacitada, as gerentes de enfermagem têm planos que incluem a redução da carga de trabalho, redução do número de vínculos empregatícios, além da própria aposentadoria.

Muitas gerentes de enfermagem acumulam dois vínculos empregatícios e têm expectativa de reduzir a jornada de trabalho. Nesse 
sentido, vislumbram melhoria na qualidade de vida, a partir da manutenção de apenas um vínculo empregatício, conforme pode ser verificado a seguir:

A gente sai daqui, mas a gente não desliga daqui. Então você fica com a cabeça... tem um móvel que a gente carrega, qualquer coisa a gente é acionado, então assim... E a gente que já tem um certo tempo na profissão, que já trabalhou na assistência, em várias áreas dentro do assistência... Tem uma hora que você tem que... eu particularmente estou doida para trabalhar em um lugar só, poder dar o melhor de mim. Você sabe que você acumulando muitas atividades você não consegue dar o melhor de você, não consegue. Isso é físico, é físico. (G5).

Eu também trabalho em outra instituição, que tem os mesmos problemas e... sou mãe, dona de casa... Nós mulheres inventamos essa história, né, de ser as super poderosas... a gente paga por elas... e muito caro, é muito caro (...) Eu tenho todos os dias ocupados, não tenho tempo de ir no médico (ri).... só quero chegar em casa, tomar um banho, jantar... não quero nem ver os meninos... (ri)... as coisas da casa... ah, deixa para amanhã...(G4).

As gerentes almejam ter mais equilíbrio em suas vidas, a fim de proporcionar isso também à equipe de enfermagem e minimizar os desgastes inerentes do processo de trabalho. Para isso, elas pretendem também cuidar da sua saúde física e mental, por meio de atividade física, psicoterapia e mais tempo para lazer:

Você tem que se manter equilibrado para que as outras pessoas também se mantenham. 0 coordenador, depois o supervisor de turno, o enfermeiro de gerencia de cuidado, até o técnico e 
auxiliar de enfermagem da portaria... todos que estão ligados à gente (...) faço terapia, até tem 2 meses que eu entrei de férias, mas até semana passada já liguei para ela e já quero recomeçar essa semana (G1).

Você está entendendo?, então as pessoas às vezes confundem, acham que você pode ser tudo, mas você tem que buscar esse equilíbrio que você não pode... tem que ver o lado profissional, o lado da instituição e o lado pessoal... buscar esse equilíbrio (G6).

Uma condição muito boa fora daqui. Quando saio daqui, ir para um lugar que é bom, que eu gosto, a minha casa... então assim... que me fortalece para voltar para cá de novo e enfrentar tudo isso (G9).

Vou caminhar... indo e voltando a pé da minha casa... que não moro muito longe... por as minhas idéias no lugar, entende? ... coisa que me faz bem. (G8).

... estratégias para não adoecer... para não me deixar adoecer... não podemos fazer tudo ao mesmo tempo, nós temos que ter calma... -, a demanda é muito grande (G7).

As gerentes também almejam investir na sua qualificação profissional, seja concluindo o pós graduação, aplicando o conhecimento na prática e ocupando outros espaços, a partir, da construção da ciência:

O que me move é exatamente ver a enfermagem ocupar o espaço que ela tem que ocupar dentro da equipe, entendeu?, é levantar a moral dela mesmo, porque eu acho assim... quando você faz ciência, quando você tem conhecimento, você vai longe (G7). 
Me atualizar dentro do que é possível e fazer alguma coisa com o grupo... (G8).

A gente quer que... e pela instituição...como eu digo, aqui eu vi nascer e aqui vou me aposentar. Estou correndo atrás de uma capacitação melhor e de repente, ainda pela questão da idade, vou sair da parte administrativa e vou para a parte assistencial. Porque eu com doutorado já poderia ir para a parte... eh... não é assistencial... é para a parte...acadêmica. Então existe também esse pensamento...(G6).

O trecho a seguir, evidencia a fala de uma gerente de enfermagem que espera aplicar o conhecimento obtido com o curso de mestrado na prática profissional, melhorando as condições de trabalho dos servidores:

Pois é... Eu não sei... Inicialmente a vontade que eu tenho, quando você... sabe? quando está com tanta coisa boa na cabeça... você fala, todo um trabalho... é todo um envolvimento... porque você se envolveu, se envolveu, sabe? aí você é responsável. Porque enquanto você não sabe o que está acontecendo... Mas a partir do momento que você tem conhecimento... Não sei, se continuar eu acho que vai dar uma coisa muito boa, muito boa...(G3).

Os trechos apresentados a seguir, revelam pelos anos de trabalho dedicados à instituição, as gerentes de enfermagem sentem que já contribuíram de forma expressiva para o desenvolvimento da instituição e da enfermagem, sendo assim, esperam por meio da aposentadoria, uma vida diferente nos próximos anos: 
Porque eu... programei a minha vida todinha, vou trabalhar 30 anos de serviço, e eu quero aposentar, e eu quero ir para o meu sítio... eu quero ver as minhas araras... meus tucanos, passarinhos, quero ver pôr do sol... né... quero aproveitar, quero ver o nascer do sol, quero isso... quero qualidade de vida! (G3).

Parece que eu passei a minha energia todinha, tentando resolver os problemas dos outros, tentando resolver essas questões aqui dentro...estou querendo descansar, são 12 anos, né? (G2).

A gente cansa... quando te falo que às vezes a gente cansa dessa rotina... (G1).

No próximo capítulo, apresento o tipo vivido identificado por meio das categorias concretas identificadas na ação de gerenciar a força de trabalho incapacitada, a partir da análise dos discursos das gerentes de enfermagem, tendo como referencial teórico, a fenomenologia social. 
6. Apresentação do Tipo Vivido 
As categorias concretas obtidas por meio dos discursos das enfermeiras gerentes de hospitais brasileiros desvelaram as estruturas de significados subjetivos da ação de gerenciar a força de trabalho em enfermagem incapacitada e permitiram a construção do tipo vivido das gerentes de enfermagem, tendo como pressupostos os "motivos porque" e os "motivos para", os quais representam as características típicas da vivência de um determinado grupo social.

Nesse sentido, para Schütz, a compreensão da conduta dos outros é possível mediante o exame do processo de tipificação, ou seja, podemos compreender as condutas se descrevermos os esquemas de interpretação apreendidos e utilizados pelos atores, para entender 0 significado do que estão fazendo, fazem ou fizeram (Souza, 2012).

As características típicas da vivência desse grupo social representam, portanto, não um indivíduo, mas um grupo social que vive num dado contexto social, atuando e interagindo com outros atores sociais. Portanto, a tipificação não representa uma gerente de enfermagem em particular mas, um grupo de pessoas que vivencia uma dada situação e que diante desta, possui condutas e comportamentos típicos e projetam suas intenções com vistas à transformação de uma realidade concreta.

Ao gerenciar a força de trabalho incapacitada, as gerentes revelam que reconhecem a problemática e a gravidade do adoecimento e da incapacidade dos trabalhadores de enfermagem e identificam as cargas e os inúmeros processos de desgaste presentes no cotidiano de trabalho. Nesse contexto, as gerentes vivenciam sentimentos de angústia, conflito e impotência, relacionados às exigências em relação à produtividade, à qualificação da assistência de enfermagem e segurança dos usuários bem como à proteção dos trabalhadores de enfermagem.

Ainda assim, os discursos apontam que as gerentes conseguem experienciar prazer no processo de trabalho gerencial, pelo reconhecimento 
do grupo, por acreditarem no seu papel na proteção à saúde dos trabalhadores de enfermagem e na manutenção de um sistema de saúde que atenda às demandas da população.

Frente às dificuldades descritas anteriormente, as gerentes de enfermagem, organizam o processo de trabalho visando o atendimento dos pacientes com segurança e com a redução dos agravos aos trabalhadores.

Tratando-se das expectativas da gestão da força de trabalho incapacitada, as gerentes vislumbram uma gestão mais participativa, com espaço para escuta e acolhimento aos trabalhadores, criando uma cultura institucional de cuidado ao cuidador. O investimento em recursos humanos também surge como um projeto de ação, contemplando lutas sindicais e espaços, junto à categoria, a fim de que a problemática da força de trabalho em enfermagem seja melhor compreendida e transformada no cenário nacional. Reforçam a importância da notificação adequada e precoce dos agravos ocorridos com os trabalhadores, tendo em vista a necessidade de obter-se dados precisos em termos quantitativos e qualitativos da força de trabalho em enfermagem além da valorização de suas potencialidades.

A redução da carga horária de trabalho, a qualificação profissional e a aposentadoria com vistas à melhoria da qualidade de vida, representam ações para o futuro das gerentes de enfermagem, evidenciando a trajetória de um grupo social que se dedicou incansavelmente para garantir uma assistência qualificada aos pacientes e preservar a força de trabalho em enfermagem brasileira. 


\section{Discussão dos Resultados}


Considerando o cenário atual de adoecimento e incapacidade da força de trabalho em enfermagem, a presente pesquisa, fundamentada na Fenomenologia Social de Alfred Schütz, permitiu compreender o típico na ação social de gerenciar a força de trabalho incapacitada, a partir da vivência de gerentes de enfermagem de hospitais públicos universitários do Brasil.

Para Schütz, o mundo da vida cotidiana é um mundo prático, onde as questões que mobilizam as pessoas não são voltadas às questões existenciais, mas à prioridade da prática, das respostas às demandas e necessidades da vida (Souza, 2012). Nesse sentido, ao desvelar o fenômeno gerenciar a força de trabalho em enfermagem incapacitada sob a ótica de gerentes de enfermagem, foi possível identificar uma vivência repleta de desafios, além da ambiguidade entre a angústia e o prazer com o cotidiano do processo de trabalho. Como resultado dessa vivência, as gerentes de enfermagem projetam ações intencionando a melhoria na gestão de pessoas, considerando questões como a incorporação de uma gestão mais participativa, a incorporação de políticas de recursos humanos, além da ressignificação pessoal relacionada à carreira e a própria vida futura.

$\mathrm{Na}$ fenomenologia social de Schütz, toda experiência e interpretação do mundo cotidiano baseiam-se num estoque de experiências anteriores a ele, às nossas próprias experiências e àquelas transmitidas pela educação. Desse modo, todas elas funcionam como um código de referência, e como tal, servem-nos como orientação, e aparecem sob a forma de um conhecimento à mão, uma vez que a consciência organiza o conjunto das experi $\square$ ncias como dep $\square$ sitos, compondo com isso um "arquivo" (Souza, 2012).

Ao aproximar-se do mundo vida das gerentes de enfermagem, diante da problemática da incapacidade dos trabalhadores de enfermagem, foi possível perceber, que para organizar a dinâmica de trabalho, as 
enfermeiras utilizam todo um estoque de conhecimento, construído e sedimentado ao longo da vida, objetivando reduzir os processos de desgaste nos trabalhadores de enfermagem e garantir uma assistência de enfermagem segura.

A importância da prática gerencial, bem como a participação dos enfermeiros e o espaço que ocupam na dinâmica do processo organizacional das instituições de saúde contemporâneas, remetem-nos a pensar no caráter complexo e polêmico da gestão, que por conseguinte, constitui-se em desafio teórico-prático para os gestores do setor saúde, especialmente os enfermeiros, que têm sobre si responsabilidades de gerir unidades e serviços. Neste sentido, os saberes constituem-se em importante recurso de ação e se traduzem num instrumento legitimador do trabalho de diferentes profissionais, da mesma forma que se revertem em fontes de autonomia, autoridade e poder dos sujeitos no contexto de suas práticas (Ferraz, Gomes, Mishima, 2004).

A trajetória biográfica das gerentes de enfermagem revela um olhar atento ao outro, onde elas utilizam o conhecimento e um conjunto de habilidades, receitas, modelos de ação para gerenciar a problemática de recursos humanos em enfermagem, caracterizada pelo elevado número de absenteísmo, presenteísmo e pelos inúmeros conflitos, decorrentes da incapacidade da força de trabalho.

Assim, ao dizer que uma situação é biograficamente determinada, Schütz afirma que ela possui uma história e corresponde a sedimentação de todas as experiências prévias do indivíduo, organizadas e disponíveis, em seu estoque de conhecimento, pertencente somente aquele indivíduo (Wagner, 2012).

Schütz refere ainda que as experiências diretas do mundo social são descritas como situação de face a face, a relação entre o outro e eu, onde a orientação em direção ao outros, só se faz, por um conjunto de 
motivos que são a causa em vista da qual se desenrola a ação (Capalbo,1998).

Observou-se que na relação face a face, as gerentes de enfermagem de todos os cenários brasileiros reconhecem a gravidade dos problemas de saúde dos trabalhadores de enfermagem, caracterizado pela prevalência dos distúrbios osteomusculares e dos transtornos mentais. No cotidiano de trabalho, as gerentes de enfermagem percebem as queixas constantes de dor, as limitações físicas, decorrentes da doença osteomuscular, e também, o sofrimento psíquico manifesto ou velado pelos sujeitos.

Os problemas osteomusculares têm sido a principal causa de incapacidade nos trabalhadores de vários países e a sua alta prevalência tem sido explicada por transformações no mundo do trabalho, caracterizadas pelo estabelecimento de metas e produtividade, aumento da competitividade, ausência e impossibilidade de pausas espontâneas, atenção para não errar, além de mobiliário e equipamentos que não propiciam conforto aos trabalhadores (Brasil,2012).

$\mathrm{Na}$ enfermagem, são muitos os estudos que descrevem a problemática das LER/DORT, utilizando diferentes vertentes teóricometodológicas, evidenciando o sofrimento dos trabalhadores e o seu impacto nos serviços de saúde (Silva, 2012; Leite, Merighi, Silva, 2011; Martins, 2011; Loisel, et al, 2002 ).

Pesquisa internacional comparou os fatores de risco físico e psicossocial para distúrbios osteomusculares entre enfermeiras no Brasil e na Itália e apesar das possíveis diferenças de condições de trabalho entre os países, não foram observadas grandes inconsistências entre enfermeiras italianas e brasileiras estudadas com relação à prevalência de dor lombar ou deficiência, sendo os problemas músculo esqueléticos, grande causa de incapacidade laboral (Carugno, et al, 2012). 
Estudo nacional realizado em um hospital universitário identificou 176 laudos médicos contendo restrições de trabalho prescritas no período de três anos, sendo as restrições mais frequentes, as ergonômicas (78,6\%), com as seguintes recomendações: não levantar nem transportar peso e não executar movimentos repetitivos. Os dados evidenciam ainda uma média de duas restrições por laudo médico, sendo 79,5\% delas definitivas (Gurgueira, Alexandre, 2006).

Os transtornos mentais e comportamentais nos trabalhadores de enfermagem também são alvo de preocupação nos serviços de saúde, haja vista, às cargas psíquicas, presentes no cotidiano de trabalho e a sua associação com os problemas musculoesqueléticos.

O adoecimento por estresse, transtornos mentais comuns, burnout além do risco para o suicídio em trabalhadores de enfermagem, têm sido descritos na literatura, relacionados não somente às questões relativas ao cuidado dos pacientes, contato diário com o sofrimento e morte, mas à organização do trabalho, caracterizada por hierarquia rígida, supervisão estrita e controle exagerado sobre o processo de trabalho (Tito, 2013; Karino, 2012; Mininel, Baptista, Felli, 2012; Gartner et al., 2012; Kirchhof, Magnano, 2009).

A atividade profissional não $\square \mathbf{s} \square$ um modo de ganhar a vida, mas também uma forma de inserção social, em que aspectos psíquicos e físicos estão fortemente implicados, no entanto, o trabalho pode ser um fator de deterioração, envelhecimento e doenças graves (Girondi, Gelbeck, 2011).

As questões relacionadas ao ambiente de trabalho e à saúde mental dos trabalhadores da saúde têm sido cada vez mais discutidas, inclusive na literatura internacional, no sentido de reconhecer elementos desencadeadores de processos de adoecimento, considerando os agravos à saúde e o impacto na qualidade da assistência (Gartner et al., 2012; Girondi, Gelbeck, 2011; LaMontagne et al., 2008; Stansfeld, Candy, 2006). 
Assim, os DORT e os transtornos mentais, responsáveis por grande parte do adoecimento e incapacidade nos trabalhadores de enfermagem, podem ser expressões de um processo de desgaste, relacionado às exigências do trabalho, que se materializam na existência de metas que os trabalhadores não conseguem atingi-las, nas múltiplas funções que devem exercer, na sobrecarga de trabalho físico e mental, nos constrangimentos que sofrem quando não conseguem ter o desempenho esperado, no isolamento e discriminação que experienciam ao perceberem que não conseguem mais manter o ritmo e no medo de passar pelo mesmo por que passaram colegas na mesma situação (Brasil,2012).

No presente estudo, foi possível perceber que a problemática da incapacidade dos trabalhadores de enfermagem causa grande sofrimento nas gerentes de enfermagem. Os discursos demonstram que as gerentes de enfermagem reconhecem e se importam com 0 adoecimento dos trabalhadores, entretanto, elas precisam engajar-se e comprometer-se com o funcionamento adequado do hospital, tentando equilibrar os danos à saúde dos trabalhadores e a proteção dos pacientes, buscando uma assistência de enfermagem livre de danos aos pacientes.

Nos últimos anos, a gestão com base em resultados, trazida para dentro das organizações, a concorrência do mercado e o demarcamento da performance de cada trabalhador, da equipe ou do departamento, reduzem o sentido e o significado do trabalho prática, e promovem a desvalorização do ser humano frente ao interesse do capital, do estado e da produtividade (Campos, 2011).

Para Schütz, a vida humana não é portanto sem interesse, indiferente ou neutral, a vida humana na atitude natural é uma vida engajada, comprometida, responsável. O mundo da vida cotidiana não é um mundo privado, mas é um mundo intersubjetivo, compartilhado com meus semelhantes, onde sabemos algo sobre a maneira segundo a qual cada um 
de nós está sintonizado com suas experiências conscientes, em outros termos, sobre as modificações de atenção de cada um (Wagner, 2012; Capalbo,1998).

Nesse sentido, o panorama de adoecimento e incapacidade da força de trabalho gera sentimentos de angústia nas gerentes de enfermagem. Os discursos revelam que uma das suas maiores preocupações refere-se às possíveis repercussões do adoecimento mental dos trabalhadores de enfermagem na segurança dos pacientes, considerando as atitudes de negligência e outros comportamentos de risco por elas verificados, como o abandono do plantão, as falhas no preparo de medicação, e o uso de medicamentos e outras substâncias químicas por parte dos trabalhadores.

A automedicação est $\square$ presente no cenário mundial, e para os trabalhadores de enfermagem, que atuam diretamente na administração de medicamentos, torna-se uma ferramenta de auxlio ao cuidado $\square$ saúde, mas pode representar um problema, se realizada sem critérios. Os principais fatores relacionados à automedicação são as $\mathrm{m} \backsim \mathrm{s}$ condições de trabalho, a dificuldade de atendimento médico e a massificação da mídia e do mercado de saúde na influ $\llbracket$ ncia da medicalização (Oliveira et al., 2013, Barros, Griep, Rotenberg, 2009).

Estudo realizado com trabalhadores de enfermagem de unidade de terapia intensiva evidenciou que $28,5 \%$ dos trabalhadores usam medicação psicoativa, $24,4 \%$ tem alguma doença psíquica, sendo a mais citada a depressão com $14,2 \%$ e ainda, $63,2 \%$ dos trabalhadores que se automedicam, utilizam drogas antidepressivas com 12,2\%. Ao utilizarem substâncias psicoativas sem acompanhamento adequado, os trabalhadores de enfermagem podem apresentar mudanças comportamentais, gerando um desempenho indesejável, baixo rendimento, altos índices de absenteísmo, 
convivência difícil, além de estarem mais susceptíveis a erros e acidentes (Vieira et al., 2013; Dias et al, 2011).

Dessa forma, a angústia e preocupação das gerentes com a segurança dos pacientes relaciona-se à percepção das mesmas quanto ao comportamento inadequado de muitos trabalhadores de enfermagem após o a utilização de medicamentos de forma indiscriminada. Essa situação faz com que as gerentes de enfermagem vivenciem um cotidiano marcado por vigilância e preocupação constantes.

Somado à essa questão, existe um importante déficit de recursos humanos, que no presente estudo é destacado de forma expressiva nos discursos das gerentes de enfermagem, traduzido pela elevação das taxas de absenteísmo assistida ao longo dos anos.

Estudo recente sobre as cargas e os desgastes ocorridos entre trabalhadores de enfermagem de um hospital universitário brasileiro revela que os trabalhadores afastam-se em períodos inferiores a 15 dias, de forma recorrente, frequentemente pelos mesmos motivos e que esses afastamentos de curtos períodos, quando analisados ao longo de 12 meses, passam a representar uma quantidade relevante de dias perdidos de trabalho. Acrescenta ainda que, as faltas, as licenças médicas, os afastamentos geram impacto não somente na saúde do trabalhador, mas, também, para o empregador, como prejuízos financeiros e queda na qualidade dos serviços prestados (Mininel et al., 2013).

O absenteísmo, é um tema que vem sendo abordado nos estudos de construção e validação de indicadores como ferramenta de gestão de qualidade em $\mathrm{RH}$ pelas consequências negativas que acarreta, tanto para o desempenho institucional com perdas da qualidade e de recursos financeiros, como para o profissional (Felli, 2010; Kurcgant et al, 2009; Lima, Kurcgant,2009). 
Observou-se a partir da situação biográfica das gerentes, que o cenário dos hospitais públicos universitários brasileiros vem sofrendo transformações ao longo dos anos, traduzidas entre outras, pela escassez de recursos humanos em termos quantitativos e qualitativos, pela multiplicidade de vínculos e pelas mudanças repentinas nos processos gerenciais. Todos esses fatores impactam diretamente na foça de trabalho e na qualidade dos serviços prestados.

A mudança do modelo de atenção, a expansão acelerada e em grande escala dos serviços, a maior responsabilidade pela implementação das políticas sociais nas esferas dos governos estaduais e municipais e a “desresponsabilização" da esfera federal em relação $\square$ manutenção dessa força de trabalho acarretaram mudanças significativas na composição e na estruturação da força de trabalho em saúde. A terceirização de serviços com diferentes números e formas de adoção, entre as diferentes esferas de governo e a heterogeneidade de vínculos é um dado importante que compõe esse conjunto de transformações que estabelecem novas relações de trabalho (Brasil, 2011).

A questão do envelhecimento da categoria e consequente aparecimento de limitações é trazida nos discursos pelas gerentes de enfermagem e é corroborada por estudos da força de trabalho em saúde no contexto nacional, onde todas as categorias apresentam envelhecimento, com exceção dos farmacêuticos (Girardi, Carvalho, 2002).

O processo de trabalho interfere na vida do trabalhador, enquanto alguns processos são redutores da capacidade para o trabalho, outros são potencializadores. Assim, quando os processos de trabalho redutores estão presentes, favorecem o surgimento das doenças, o envelhecimento precoce e perda da capacidade para o trabalho. Entretanto, quando a saúde é valorizada e os elementos que proporcionam qualidade de vida estão 
presentes e são potencializados, esses atuam como promotores de níveis elevados de capacidade para o trabalho (Hilleshein, Lautert, 2012).

$\mathrm{Na}$ verdade, a complexidade das consequências do envelhecimento da população representa uma ameaça para o desempenho da economia. Neste contexto, o aumento da participação e as taxas de emprego dos trabalhadores mais velhos são essenciais para ajudar a sustentar o crescimento econômico, e gerenciar o crescente encargo financeiro para sistemas de proteção social. Assim, políticas e instrumentos de investimento em trabalhadores mais velhos parece ser extremamente importante para prolongar a vida de trabalho e tornarem os trabalhadores mais velhos tão produtivos como seus colegas mais jovens, sinalizando a importância do fator humano como um recurso valioso para o sucesso da empresa (Znidar $\square \square$

Schütz descreve que o sujeito experiencia o mundo que esta a seu alcance como um elemento ou uma fase da sua situação biográfica única, que envolve uma transcendência do aqui e agora, na qual ele pertence, onde certos fatos, ou eventos são conhecidos pelo sujeito como inter-relacionados de modo mais ou menos típico (Wagner, 2012).

Nesse sentido, a angústia das gerentes também está relacionada ao conhecimento e/ou percepção das mesmas acerca da ausência de políticas de recursos humanos institucionais considerando o expressivo número de absenteísmo, o envelhecimento da categoria e as crescentes aposentadorias sem reposição.

As gerentes relatam ainda a multiplicidade de vínculos empregatícios presente nos trabalhadores de enfermagem, que também passa a ser uma grande preocupação, considerando o desgaste físico e mental, e possível falta de atenção nas atividades profissionais. 
A baixa remuneração como justificativa para a manutenção de dois ou três vínculos é tratada como um grave problema para a saúde ocupacional da enfermagem. Autores relatam que o salário médio para o conjunto das categorias de saúde esta em torno de 6.5 salários mínimos, sendo os menores salários os do ortoptistas e do pessoal de enfermagem (Girardi, Carvalho, 2002).

Pesquisa recente sobre a jornada de trabalho em enfermeiros de hospitais públicos evidenciou que o grupo feminino apresentou as jornadas doméstica e total mais extensas, quando comparadas às jornadas do grupo masculino e reforça a necessidade da jornada profissional como a doméstica serem consideradas nos estudos sobre a saúde do trabalhador (Fernandes et al., 2013).

Estudo descritivo, cujo objetivo foi avaliar a ansiedade e a depressão entre 211 profissionais de enfermagem de onze hospitais da cidade de Londrina-Paraná, identificou que em relação à depressão, não se observa diferença estatisticamente significante para a frequência desse transtorno entre os profissionais segundo o tipo de instituição $(p=0,801)$, porém ocorre diferença estatisticamente significante para a presença de duplo vínculo empregatício $(p=0,010)$ (Schmidt, Dantas, Marziale, 2011).

Para Schütz, não somos apenas centros de espontaneidade agindo no mundo e operando transformações nele, mas somos também meros receptores passivos de eventos que estão fora de nosso controle; situações e eventos que se impõem a nós que não são originados em atos que escolhemos realizar, mas que temos que aceitar tal como são (Wagner, 2012). Os discursos revelam que as gerentes compreendem a necessidade dos trabalhadores se vincularem a outros serviços, buscando uma melhor remuneração e consequentemente a oportunidade de oferecer melhores condições de vida para sua família. 
O mundo social, como fenômeno concreto, implica na variabilidade de perspectivas e de interesses. Ele contém estruturas típicas que o diversificam a partir de interesses variados e que são vividos por grupos sociais participantes (Capalbo,1998).

Sob a perspectiva da fenomenologia social, os diferentes grupos sociais contém estruturas típicas que o conformam naquele grupo, sendo assim expressa-se neste estudo, a partir do relato das gerentes, o perfil dos profissionais de enfermagem, predominantemente do sexo feminino, com baixa remuneração, múltiplos vínculos de trabalho, busca por qualificação, somados à carga de trabalho doméstica e dificuldades na vida pessoal.

Evidencia-se na enfermagem a divisão técnica e social do trabalho que configura uma dada composição da força de trabalho e da sua expressão enquanto fazer/saber, expressão em números de profissionais, em postos de trabalho, em estratificação das categorias. Assim a enfermagem é determinada e também determina, e conforma sua história no Brasil na conjuntura das políticas de saúde ( Pereira et al., 2009).

A literatura destaca que, parte dos trabalhadores de nível médio persegue objetivos profissionais, empenhando-se para alcançá-los, mas as possibilidades de concretizar essa formação no plano da inserção no mercado de trabalho em saúde são reduzidas. Seus esforços são, na maioria das vezes, frustrados pelas condições objetivas de suas vidas, condicionadas pela divisão social e técnica do trabalho contemporâneo (Vieira, Chinelli, 2013).

No presente estudo, observou-se que esse perfil de trabalhadores está presente em todas as regiões brasileiras, e dessa forma, a angústia, a preocupação e a sensação de impotência permeiam o mundo da vida das gerentes de enfermagem, revelando seu comprometimento e engajamento ético-legal e político com a profissão e com a instituição, no atendimento à população e na gestão da força de trabalho em enfermagem. 
Apesar desse contexto, foi possível verificar que o processo de trabalho também traz experiências positivas para as gerentes de enfermagem, uma vez que são relatados sentimentos de prazer, reconhecimento e satisfação pelo trabalho realizado. As gerentes sentem prazer no processo gerencial, especialmente por reconhecerem as necessidades dos trabalhadores de enfermagem, identificando os processos de desgaste, as restrições por eles apresentadas e por representarem um elemento-chave no encaminhamento desta problemática.

O gerenciamento em enfermagem requer preparo das chefias na competência de observação de sua equipe de maneira integral e integradora. No papel educativo e na liderança da equipe, o enfermeiro pode identificar o surgimento de doenças relacionadas ao trabalho e atuar na organização do mesmo (Batista, Juliani, Ayres, 2010).

Isso requer uma proximidade, que se dá na relação face a face entre as gerentes e os trabalhadores de enfermagem, onde a intersubjetividade $\square$ fundamental para a compreensão da existência humana. Schütz descreve que estando o homem inserido no mundo social, é necessário que estabeleça uma rede de relações sociais, as quais permeiam suas intenções e fazem parte do mundo construído pelo próprio homem (Schütz, Luckmann, 2009; Schütz, 2008).

Portanto, para essas gerentes é extremamente gratificante perceber o reconhecimento por parte do grupo, não somente na dimensão técnica do trabalho, mas na dimensão humana de ouvir, estar atento às dificuldades do grupo e buscar soluções para que eles se fortaleçam num processo tão difícil que é o do adoecimento e incapacidade.

A atividade gerencial deve em sua dimensão comunicativa, permitir a abertura de espaço, troca de idéias e levantamento das necessidades dos trabalhadores, pois o atendimento humanizado ao 
paciente deve caminhar de mãos dadas com o atendimento humanizado ao profissional de saúde (Batista, Juliani, Ayres, 2010).

Estudo realizado com o objetivo de conhecer o nível de bem-estar no trabalho de profissionais de enfermagem que atuam em um hospital universitário verificou que em relação $\square$ satisfação no trabalho, o maior índice foi referente $\square$ satisfação com a chefia, quando eles se mostraram quase satisfeitos (Alves et al., 2012).

Para o francês Cristopher Dejours (2013), o reconhecimento no trabalho esta relacionado ao julgamento sobre a qualidade do trabalho realizado, e não sobre a pessoa, no entanto, pode influenciar em termos de ganhos ou perdas no registro da identidade, uma vez que, se dá pela mediação do outro e pela inscrição do sujeito numa hist $\square$ ria coletiva, possibilitando o prazer ou sofrimento.

Alguns estudos identificaram a ambiguidade no processo de trabalho de enfermagem, caracterizada por sentimentos de sofrimento e prazer. Reforçam ainda que o prazer no trabalho pode, em muitas situações, minimizar toda a carga de sofrimento presente (Kessler, Krug, 2012; Leite, Merighi, Silva, 2007). Portanto, apesar de todos os obstáculos geradores de sofrimento e angústia vivenciados no cotidiano de trabalho, ser reconhecida e poder representar uma figura na qual os trabalhadores podem confiar faz emergir sentimentos de prazer e satisfação no trabalho das gerentes de enfermagem.

A partir dos relatos, foi possível perceber também que as gerentes de enfermagem buscam organizar a dinâmica de trabalho, fazendo trocas entre os postos de trabalho, permuta de trabalhadores entre as clínicas, alocação dos trabalhadores com restrições físicas importantes em atividades que minimizem seu esforço físico e dos trabalhadores com restrição mental em atividades que não comprometam a segurança dos pacientes. 
Pode-se destacar como ferramenta gerencial, o tempo médio de assistência de enfermagem, segundo o tipo de cuidado, por ser uma medida objetiva para a avaliação e a monitorização do quantitativo e qualitativo dos profissionais de enfermagem das unidades de internação de instituições hospitalares, uma vez que, possibilita avaliar as condições de recursos humanos existentes, frente a qualidade e a segurança da assistência de enfermagem oferecida (Rogenski et al., 2011).

O fechamento de leitos e/ou unidades temporariamente também é um recurso utilizado pelas gerentes de enfermagem do cenário nacional, a fim de assegurar o cuidado aos pacientes e não expor ainda mais os trabalhadores de enfermagem às condições de trabalho inadequadas e adoecimento.

Para o planejamento de atividades, as enfermeiras, em certos momentos, identificam a necessidade da elaboração do plano, coordenam, articulam e descrevem possibilidades, identificam os atores e os recursos envolvidos com o plano, tentando viabilizá-lo, realizando previsão de situações e possíveis alternativas para a tomada de decisão (Kawata et al., 2009).

As readaptações de trabalhadores de enfermagem acarretam problemas gerenciais, inclusive na elaboração de escalas de trabalho. Considerando-se as normas institucionais e a complexidade da assistência e dos processos de trabalho, o enfermeiro, em parceria com sua equipe, a instituição e o próprio trabalhador devem buscar soluções para essa problemática, de forma a evitar a falta de perspectiva no trabalho, a insatisfação e o adoecimento (Batista, Juliani, Ayres, 2010).

Schütz descreve que ao orientar a ação em direção à alguém, o sujeito atribui um conjunto de motivos em vista dos quais vai agir. Para tal, recorre à bagagem de conhecimento disponível (Capalbo, 1998). Nesse contexto, as gerentes utilizam seus saberes profissionais, incluindo 0 
conhecimento teórico e prático, somado à bagagem de vida para organizar o processo de trabalho. Para organizar a dinâmica de trabalho, diante do cenário de presenteísmo, as gerentes procuram sensibilizar dos demais trabalhadores quanto ao acolhimento daqueles que retornam ao trabalho com incapacidade laboral, no entanto, reconhecem que este ainda é um grande desafio.

O significado subjetivo do grupo é descrito por Schütz como um sentimento de pertencimento e compartilhamento de interesses comuns, onde existe um conjunto de hábitos mais ou menos institucionalizados, que os ajudam a interagir com os semelhantes (Wagner, 2012). Sendo assim, quando um trabalhador aparentemente não apresenta comportamentos esperados pelo grupo, tende a ser excluído, isso é verificado quando o trabalhador retorna ao trabalho com alguma restrição.

A questão de relacionamento com a equipe deixa evidente a resistência do profissional de saúde em aceitar o processo de adoecimento. Paralelamente, muitas vezes, há a não aceitação ou o questionamento da gravidade do problema por parte dos colegas (Silva, 2012; Batista, Juliani, Ayres, 2010; Leite, 2006).

Estudo recente sobre as tendências de gerenciamento de unidades de saúde e de pessoas aponta que os gestores devem apresentar responsabilidade ética e social, ter comunicação eficaz, além de saber negociar, gerir as mudanças e conflitos, desenvolver e aglutinar equipes, trabalhando com planos, ações e resultados (André, Ciampone, Santelle, 2013).

Para gerenciar a assistência prestada, o enfermeiro deve ser um profissional que precisa capacitar-se e qualificar-se para desenvolver determinadas competências e habilidades entre elas, a observação, o senso crítico e sensibilidade para analisar o "outro" e o contexto em que está inserido (Fernandes et al., 2003). Sendo assim, as gerentes verbalizam que 
reconhecer a incapacidade é essencial para organizar a dinâmica de trabalho, permitindo que os remanejamentos assegurem à manutenção da qualidade de vida no trabalho e evitem o agravamento da incapacidade laboral.

A partir dos discursos das gerentes, tendo como referencial filosófico, a fenomenologia social, foi possível identificar as expectativas na gestão de pessoas (motivos para), nas quais observa-se o desejo das gerentes de enfermagem em construir uma gestão mais participativa, participar e/ ou sensibilizar para implementação de políticas de recursos humanos em saúde e ainda, o delineamento de novos caminhos na vida e na carreira profissional.

Historicamente as enfermeiras $\mathrm{t} \square \mathrm{m}$ adotado princípios da $\square$ scola $\square$ ientfica e Clássica da Administração para gerenciarem o seu trabalho, tendo em vista a estruturação e organização do Serviço de Enfermagem nas instituições de saúde e apesar dessa raiz histórica de autoritarismo, centralização das decisões e impessoalidade nas relaç $\sqsubset$ es, observa-se na atualidade, que a introdução de novas abordagens gerenciais, est $\square$ impulsionando os gerentes a buscarem novas alternativas para organizar o trabalho (Fernandes et al., 2003).

Felli, Peduzzi (2005) descrevem o modelo histórico-social, no qual a gerencia não está voltada apenas para a organização e controle dos processos de trabalho, mas também, para a apreensão da satisfação das necessidades de saúde da população, o que implica na democratização das instituições de saúde e na ampliação da autonomia dos sujeitos envolvidos no processo de cuidado.

$\mathrm{Na}$ verdade, os modelos gerenciais expressam uma proposta que leva em conta os objetivos definidos pelo modelo assistencial, a natureza da instituição, aspectos políticos e o mapa do poder na instituição. Sem ter desenvolvido um campo de conhecimento próprio na área de 
gerenciamento, os hospitais adotaram os modelos oriundos de outros setores produtivos e com as mudanças ocorridas no mundo do trabalho, especialmente a reformulação do modelo assistencial proposto para o Brasil pelo SUS, surgem novos saberes necessários ao exercício das diferentes profissões (Bernardino, 2007).

$\mathrm{Na}$ atitude natural estamos a todo instante produzindo e reproduzindo realidades que foram criadas e recriadas antes de nós. No cotidiano, desenvolvemos um conjunto de técnicas/táticas para controlar nossas experiências. Schütz chama isso de tipificações. São como receitas que congregam características gerais e homogêneas para certas situações, coisas e contextos (Souza, 2012).

Como já descrito anteriormente, as gerentes reconhecem o processo de adoecimento e incapacidade dos trabalhadores de enfermagem e o papel fundamental exercido por elas, entretanto almejam realizar uma gestão que possibilite transformações por meio da construção coletiva, mobilizando atores em prol de melhoria nas condições de trabalho.

A conscientização dos gerentes de enfermagem quanto à problemática da saúde dos trabalhadores é destacada em vários estudos, haja vista sua responsabilidade gerencial sobre os recursos humanos e a competência para enfrentar os desafios decorrentes da incapacidade da força de trabalho (Silva, 2012; Mininel, 2011; Silva, 2011; Leite, 2006).

Atualmente, todos os esforços para combater o adoecimento dos trabalhadores da área da saúde são fundamentais, e todos os estudos que focalizam os problemas relacionados à saúde física e mental dos trabalhadores têm contribuído para melhor compreensão da situação laboral desses profissionais e para o início da conscientização dos gerentes quanto à importância de elaboração de medidas preventivas (Schmidt, Dantas, Marziale, 2011). 
As gerentes esperam desmistificar a incapacidade para o trabalho e verbalizam a necessidade de estabelecer estratégias para valorizar os trabalhadores de enfermagem, regatando as suas potencialidades e a contribuição dos mesmo para o funcionamento adequado dos serviços.

$\square$ as duas $\square$ timas décadas o tema do reconhecimento tornou-se uma importante chave de leitura das ciências polticas para a compreensão de diversos fenômenos sociais contemporâneos. No campo da psicologia das organizações e do trabalho, particularmente a relevância do tema também se faz notar pelo crescente $\mathrm{n} \llbracket$ mero de estudos dedicados a compreender suas relações com tópicos como identidade, sofrimento, saúde, motivação e percepção de justiça e reciprocidade nas relações intersubjetivas nas organizações (Bendassoli, 2012).

O trabalhador readaptado frequentemente se sente isolado, mesmo sendo parte da equipe de enfermagem e ao ser remanejado para outro setor, nem sempre está qualificado para desempenhar a nova função, além de, por vezes, ser recebido como mais um problema, quando suas atividades, na maioria das vezes, são consideradas menos complexas, portanto, desvalorizadas (Batista, Juliani, Ayres, 2010).

Os gerentes/ coordenadores são elemento chave em programas que facilitam o retorno ao trabalho de trabalhadores acidentados ou doentes, mas poucas pesquisas documentam as competências necessárias para o sucesso nesse papel. Estudo com 75 coordenadores experientes em retorno ao trabalho foi realizado para identificar as competências individuais. As competências foram classificadas em oito grupos: administração, atributos pessoais individuais, recolha de informação, comunicação, credibilidade profissional, avaliação, resolução de problemas e gestão de conflitos (Pransky et al., 2010).

Nesse contexto, as gerentes desempenham papel muito importante, em razão de sua grande proximidade com os trabalhadores de 
enfermagem com restrições, utilizando-se de ferramentas gerenciais para atuar como elo entre os demais trabalhadores de enfermagem, os supervisores e a equipe multiprofissional.

Estudo sobre as ferramentas gerenciais utilizadas pelos enfermeiros no cotidiano de trabalho descreve que os atributos mobilizados pelas enfermeiras envolvem: atitudes que podem indicar valorização do outro e preocupação com direitos e deveres no e para o trabalho; conhecimentos sobre a saúde do trabalhador, da dinâmica e da rotina da unidade, de princípios éticos (como justiça, tolerância e responsabilidade), das atribuições de cada trabalhador; habilidades relativas ao tipo de linguagem, à tomada de decisão e à interação (Kawata et al., 2009).

Evidencia-se na literatura que a experiência da readaptação é sofrida, quando essa se dá, de forma impositiva, sem a participação do trabalhador no processo, entretanto, quando esse processo é construído no coletivo, com a equipe responsável pelo seu problema de saúde, ou nos serviços públicos de saúde, com a gerência a que está subordinado e os colegas, o processo deixa de ser sofrimento para o trabalhador de enfermagem para se tornar satisfação em ser útil e produtivo novamente (Batista, Juliani, Ayres, 2010).

Os discursos revelam que apesar de organizarem a dinâmica de trabalho, por meio de acordos e remanejamentos, a sensibilização dos trabalhadores acerca do adoecimento, da incapacidade e absenteísmo ainda precisa ser melhorada no sentido de comprometer mais os indivíduos.

Estratégias para resgatar os valores éticos da profissão, são expectativas para a ação das gerentes, vislumbrando um maior compromisso com o trabalho e com o grupo no qual os trabalhadores se inserem. Pesquisa recente verificou frágil compromisso afetivo dos trabalhadores de enfermagem com a organização e dúvidas em relação ao grau de envolvimento no trabalho (Alves et al., 2012). 
As gerentes de enfermagem desejam implementar reuniões, oficinas e encontros para criar uma cultura institucional de compromisso com o paciente e com a equipe de trabalho, no sentido de favorecer processos de trabalho mais saudáveis e promotores de qualidade de vida.

Esses aspectos colocam para a enfermagem o desafio da construção de uma prática que de certo modo faz tensionamentos entre o que se faz hegemonicamente e a mudança pretendida nos modos de operar, pesquisar, cuidar, ensinar para que seus agentes desenvolvam ações por meio da interação de práticas e de saberes, superando a equipe agrupamento em que os agentes e saberes estão em um mesmo serviço, mas não constroem processos coletivos de cuidar (Pereira et al., 2009).

Enquanto a ação esta em curso, o ator só tem em vista os motivos para, estes motivos são subjetivos, ao passo que a categoria dos motivos porque são acessíveis ao observador por reconstrução a partir da ação já realizada (Capalbo,1998).

Os discursos evidenciam a expectativa das gerentes de enfermagem quanto ao investimento em políticas de recursos humanos em saúde, em termos quantitativos, com a sensibilização de órgãos e entidades de classe, como o Conselhos Federal e Regional de Enfermagem, e de outras instâncias como a reitoria e o governo, para a abertura de concursos, contratação de pessoal de enfermagem nos hospitais universitários.

Durante um longo período, que se iniciou nos anos 1950 e se estendeu até meados dos anos 1980, a questão de recursos humanos em saúde, não se traduzia em foco de atenção vinculado à organização da produção do trabalho na sociedade. A abordagem adotada pelo setor incluía essa questão como mais um insumo, ao lado dos recursos materiais e financeiros (Brasil, 2011). 
Assim, a necessidade de avanços na gestão de recursos humanos nos serviços públicos de saúde é motivo de debates há anos e as dificuldades presentes nesta área geram desafios para gestores nas três esferas de governo. A produção dos serviços de saúde depende da estrutura física, material e tecnológica disponível e da existência de profissionais qualificados e motivados para transformar insumos em resultados (Scalco, Lacerda, Calvo, 2010).

Nesse sentido, as gerentes destacam a melhoria nas condições de trabalho, incluindo o aspecto físico, tecnológico, melhores salários, e a necessidade de um plano de carreira que possa manter o trabalhador em apenas uma instituição, transformando a atual situação de adoecimento e incapacidade nos trabalhadores de enfermagem.

A enfermagem enquanto uma prática social, estabelece relações com outros trabalhos, com as dimensões econômicas, culturais e sociais das instâncias que compõem a estrutura de uma sociedade. Enquanto uma prática de saúde é conformada por essa teia das relações sociais e também contribui para conformação das outras práticas sociais (Pereira et al., 2009).

Portanto, a ação de gerenciar a força de trabalho incapacitada nunca está isolada, desvinculada do mundo da vida, mas, em completa sintonia com a realidade social que as gerentes vivenciam. Para Schütz, aquilo que concebemos previamente na projeção de nossas ações é um estado de antecipação e o domínio dos eventos futuros que podemos influenciar com nossas ações, consideramos a nós mesmos como realizadores desse evento (Wagner, 2012).

Nessa perspectiva, os discursos evidenciam que tratando-se de políticas de recursos humanos, as gerentes de enfermagem esperam por políticas institucionais e públicas voltadas à saúde do trabalhador, isso inclui melhoria nos processos de vigilância dos agravos, incluindo a notificação e o seu monitoramento adequado. 
A Constituição Federal de 1988 determinou a incorporação do campo de saúde do trabalhador no âmbito do direito universal $\square$ saúde e competência do SUS (arts. 196 e 200 da Constituição Federal. A saúde do trabalhador também $\square$ citada em dez dispositivos da lei de concepção do Sistema Único de Saúde - SUS - Lei n. 8.080/90 e definida no art. 60 dessa lei), inclusive as que são tradicionalmente de competência da área do trabalho, deixando $\square$ Previdência Social as atividades reguladoras do seguro social. Entretanto, a saúde do trabalhador revela um momento de viabilização das conquistas obtidas no plano jurdico-institucional que abrangem direitos garantidos na legislação, mas que, na prática, ainda encontram dificuldade de sua efetivação (Olivar, 2010).

Os estudos indicam que os trabalhadores que sofrem acidentes de trabalho têm prejuízos econômicos e sociais, com impactos na vida pessoal, familiar e devido à precariedade de informações sobre a ocorrência desses, torna-se difícil analisar o real impacto do acidente de trabalho na vida do trabalhador. Há necessidade de estudos sobre políticas administrativas e de saúde ocupacional, pois somente a prescrição das restrições de trabalho não resolve, em longo prazo, a exposição dos trabalhadores aos riscos ocupacionais. Deve-se realizar, em conjunto, um programa institucional de acompanhamento da restrição de trabalho, de educação e treinamento constantes, e de mudança do posto de trabalho (Rodrigues et al., 2012; Gurgueira, Alexandre, 2006).

Dessa forma, monitorar a capacidade dos trabalhadores para o trabalho pode ser uma importante ferramenta para a gestão de pessoas. Amplos estudos de acompanhamento do Instituto de Saúde Ocupacional na Finlândia têm prognosticado, de forma confiável, mudanças na capacidade para o trabalho por meio do Índice de Capacidade para o Trabalho (ICT) em diferentes grupos ocupacionais. Apontam ainda que, as diferenças individuais na capacidade para o trabalho aumentam com a idade e que os fatores que levam à sua diminuição começam a se acumular na meia idade 
e são verificados em trabalhadores com cerca de 45 anos, sugerindo que o investimento na manutenção da capacidade de trabalho e na capacidade funcional produz resultados em poucos anos e a melhoria da capacidade permanece com os trabalhadores quando eles se aposentam e entram na terceira idade (Tuomi et al., 2005; Ilmarinen, Tuomi, Klockars,1997).

Outros estudos internacionais também reiteram que quanto antes se detecta um agravo, mais precocemente pode se iniciar o tratamento e a chance do trabalhador permanecer afastado por longos períodos torna-se menor. $\mathrm{E}$ ainda, observa-se que quanto maior o tempo de duração do afastamento, maiores são os obstáculos para o retorno ao trabalho (Loisel, Durand, 2005).

Para Schütz um motivo pragmático governa a nossa atitude natural em relação ao mundo da vida cotidiana e o mundo assim concebido, é sempre algo que temos de modificar com nossas ações (Wagner, 2012). Nos discursos, observou-se que as gerentes de enfermagem esperam deixar um legado de sua trajetória profissional, implementando medidas para promover a saúde dos trabalhadores de enfermagem, incluindo o suporte de outros profissionais, como o psicólogo, o fisioterapeuta, o terapeuta ocupacional, entre outros.

Um ensaio clínico com o objetivo de verificar a eficiência da massagem para diminuir a lombalgia ocupacional e sua influência no desempenho das atividades laborais e de vida, na equipe de Enfermagem concluiu que o protocolo de massagem foi eficiente na diminuição da lombalgia ocupacional, apontando a técnica descrita como terapia passível de ser utilizada dentro das instituições hospitalares, em benefício dos funcionários (Borges et al., 2012).

A gerência de enfermagem pode, por meio conhecimento de sua equipe, de maneira integral, promover ações organizativas e educativas que melhorem a qualidade de vida dos trabalhadores, não somente pelas ações 
que são de sua competência, mas também pela articulação com os níveis institucionais que mantêm interface com a problemática (Batista, Juliani, Ayres, 2010).

A avaliação individualizada cabe no tocante aos aspectos clínicos para que um programa terapêutico interdisciplinar seja definido, com diversos recursos aplicados de forma individual e/ou grupal. Mas, quando se trata de eliminar ou controlar as condições desencadeantes ou agravantes de dor musculoesquelética ou transtornos psíquicos, é preciso que o foco seja na organização do trabalho. Medidas isoladas e restritas a cada caso dificilmente têm o alcance necessário para a conquista de uma nova forma de trabalhar, que seja promotora da saúde (Maeno, 2011).

Estudo avaliou a capacidade para o trabalho de 195 enfermeiros de um hospital universitário, a partir do instrumento Índice de Capacidade para o Trabalho (ICT) e evidenciou que programas em família, festas, passeios e confraternizações afetam de modo positivo a capacidade para o trabalho, e os enfermeiros que realizam essas atividades possuem ICT médio de 42,1, sendo significativamente maior ao do grupo que não as realiza (p-valor=0,009) (Hilleshein, Lautert, 2012).

O investimento nos recursos humanos da instituição a partir de treinamentos, oficinas, além de pausas para confraternizações também é sugerido pelas gerentes de enfermagem, com vistas à valorização do potencial humano existente e consequentemente a melhoria nos processos de trabalho.

As políticas de recursos humanos devem contemplar ações de formação e desenvolvimento dos profissionais. As conferências nacionais de saúde e as conferências específicas de recursos humanos, que acontecem na saúde desde 1941, detectaram muitos problemas da área, mas muitas deliberações destes fóruns ainda não se efetivaram. Alternativas simples, como as reuniões em serviço, podem contribuir na qualificação dos 
profissionais, na aproximação dos membros das equipes e na produção de soluções para a melhoria das ações e serviços de saúde (Scalco, Lacerda, Calvo, 2010).

O investimento em educação permanente dos trabalhadores deve, também, instrumentalizar sobre a saúde e condições de trabalho, porque dessa forma, todos podem ter a oportunidade de participar dos processos decisórios institucionais que impliquem em melhores condições de trabalho e redução dos agravos (Felli,2002).

Para compreender os fenômenos sociais, $\square$ necessário apreend $\square$ los pelo código das motivações humanas, dos fins e meios, do planejamento, enfim, das categorias da ação humana (Zeferino, Carraro, 2013). Portanto, ao aproximar-se do mundo da vida das gerentes de enfermagem também evidenciou-se a necessidade das mesmas re-olharem para si e para o seu futuro profissional e pessoal.

Os discursos revelam que as gerentes de enfermagem esperam melhorar a sua qualidade de vida, incluindo a qualidade de sono e a redução da carga de trabalho uma vez que algumas gerentes de enfermagem ainda acumulam dois ou três vínculos de trabalho, seja em outro serviço hospitalar ou na universidade.

Pesquisadores internacionais investigaram como o nível de exposição ao trabalho em turnos durante a vida profissional de um indivíduo pode estar relacionado com a qualidade do sono durante a aposentadoria e verificou que a exposição prévia ao trabalho em turnos está relacionada não somente com problemas de sono na fase produtiva como durante a aposentadoria (Monk et al, 2013).

Os discursos evidenciam que as gerentes de enfermagem que ainda estão distantes da aposentadoria esperam ter maior equilíbrio em suas vidas por meio de atividades como psicoterapia, caminhada, ou lazer. 
Os trabalhadores muito envolvidos com suas atividades laborais $\mathrm{t} \square \mathrm{m}$ uma tendência de alterar sua rotina pessoal, familiar e social, restando-Ihes, por exemplo, apenas os dias de folga para resolver problemas de todas as ordens. Por isso, eles muitas vezes têm de postergar os planos consigo e com a própria família por causa da falta de tempo disponível (Pires et al, 2013).

O investimento no aperfeiçoamento científico também surge como um novo caminho, tanto para transformar o conhecimento numa prática consolidada por meio da pesquisa como na atividade docente para formar novos enfermeiros.

conhecimento especializado e a busca pela autonomia profissional articulam-se $\square$ necessidade da atividade poltica para potencializar o credencialismo da profissão. Isso se configura na promoção contınua de desenvolvimento de projetos e incentivos pesquisa, para o aprimoramento do saber e da competência em enfermagem (Bellaguarda et al, 2013).

O desejo de aposentadoria está presente no discurso de algumas gerentes, a partir da crença de que ao longo da vida profissional contribuíram com o sistema público de saúde e agora esperam envelhecer com mais tranquilidade.

Estudo realizado no âmbito da saúde pública averiguou quais são as representações do processo de envelhecimento para profissionais da saúde e os dados analisados revelaram que as palavras mais representativas para expressar o envelhecimento foram aposentadoria e descanso. O fator que mais influenciou o bem-estar e o cuidado do indivíduo idoso foi uma boa rede familiar (Fonseca et al., 2008).

Nesse sentido, as gerentes de enfermagem do presente estudo justificam o sacrifício da multiplicidade de vínculos durante a trajetória 
profissional para que pudessem desfrutar no futuro suas conquistas também no âmbito material.

Estudo recente verificou que a permanência no mundo do trabalho, quando $\mathrm{j} \square$ se alcançou ou se est $\square$ por alcançar a condição para obter a aposentadoria, $\square$ vivenciada de forma diversificada, sendo individualizada para cada trabalhador de acordo com as suas subjetividades. Reforça ainda que o trabalho não deve ser a única alternativa na vida das pessoas, e sobre este aspecto, é importante que os indivíduos se prepararem para uma aposentadoria saudável (Fonseca et al.,2008).

A literatura internacional valoriza o investimento nos trabalhadores durante a vida produtiva no sentido de evitar danos à saude, possibilitando a maior contribuição dos mesmos com a economia e consequentemente, garantindo aos sujeitos uma vida produtiva e sem limitações apos o tempo de trabalho ( $\square$ nidar $\square$ $\square$ a, 2012; Tuomi et al.,2001).

Infindáveis possibilidades surgem para as gerentes de enfermagem, a partir da experiência desvelada foi possível observar que elas reconhecem sua contribuição substancial para a enfermagem e para a população, fazendo história no sistema público de saúde brasileiro e agora, vislumbram no futuro um tempo para outras atividades que Ihes tragam prazer, qualidade de vida e realização pessoal. 
8. Considerações Finais 
Ao desejar compreender a ação de gerenciar a força de trabalho em enfermagem incapacitada sob a ótica de gerentes de enfermagem do cenário nacional, acreditei que o desvelar deste fenômeno pudesse delinear estratégias para intervir numa realidade preocupante dos serviços de saúde.

Para tanto, foi necessário investigar o mundo da vida das gerentes, ou seja, a realidade social na qual elas se inserem, apreendendo suas tipificações. Essa investigação me possibilitou conhecer a experiência de gerenciar a força de trabalho incapacitada (motivos porque) e as expectativas para a gestão de pessoas (motivos para).

Os discursos evidenciaram um cotidiano de ações com vistas à manutenção da estrutura organizacional, marcado por inúmeras dificuldades e conflitos, onde o acervo de conhecimento se faz essencial para o processo de trabalho gerencial. A partir da relação face a face, as gerentes percebem $\mathrm{O}$ adoecimento e incapacidade da categoria profissional, reconhecendo situações graves no cotidiano de trabalho relacionadas ao adoecimento psíquico e utilização de substâncias químicas, o que as obriga uma vigilância constante nos processos de trabalho a fim de evitar a ocorrência de danos aos pacientes e preservar a qualidade da assistência de enfermagem.

O envelhecimento da força de trabalho também é trazido neste estudo pelas gerentes, evidenciando um agravamento do contexto, tendo em vista as limitações fisiológicas inerentes ao ciclo vital. Sob este aspecto, as gerentes relatam a ausência de uma politica de recursos humanos comprometida com a reposição de pessoal, o que tende a agravar o cenário dos serviços de saúde no Brasil.

A busca pela excelência do trabalho, alcance de metas e incremento da produtividade associadas às necessidades da população nos serviços de saúde impulsionam as gerentes do cenário nacional ao desenvolvimento de competências gerenciais para atuarem diante das novas 
demandas. Entretanto, esse cotidiano de trabalho intenso, com tantas dificuldades gera muito sofrimento, considerando que as enfermeiras tentam incansavelmente equilibrar a segurança dos usuários com a segurança dos recursos humanos.

Por outro lado, o reconhecimento pelo trabalho realizado faz emergir nas gerentes, sentimentos de prazer e satisfação, uma vez que trabalham para minimizar os agravos dos trabalhadores de enfermagem, assegurar uma assistência de enfermagem qualificada e colaborar com o sistema público de saúde.

Apropriando-me da análise filosófica de Alfred Schütz, foi possível perceber os motivos que sustentam a experiência vivenciada na ação de gerenciar a força de trabalho incapacitada e os motivos que projetam as gerentes para o futuro. Neste sentido, a responsabilidade no processo gerencial é explicitada pelas gerentes, onde as mesmas reforçam o papel essencial da gerência sobre os recursos humanos, na articulação de pessoas e instâncias a fim de preservar a maior riqueza institucional: a força de trabalho.

Dessa forma, fica evidente que a ação de gerenciar a força de trabalho incapacitada exige um olhar cuidadoso não somente aos trabalhadores que experienciam muitas restrições mas, ao grupo de trabalhadores que esta saudável e atua junto com os demais, para a compreensão e colaboração no processo de transferências e remanejamentos de trabalhadores entre os setores.

Tratando-se das expectativas para a gestão de pessoas, as gerentes de enfermagem esperam portanto, realizar uma gestão mais participativa, capaz de acolher os trabalhadores de enfermagem, por meio do diálogo e do trabalho coletivo. A institucionalização de uma cultura de cuidado à força de trabalho é sinalizada pelas gerentes de todos os 
cenários, evidenciando o comprometimento com uma causa importante que impacta a saúde pública no Brasil.

Assim, a realização deste estudo aponta para a reflexão acerca de estratégias na gestão de recursos humanos a fim de reduzir as incapacidades para o trabalho e as consequências econômicas e sociais dela decorrentes. Portanto, fortaleço a minha crença de que para compreender o adoecimento e a incapacidade para o trabalho, é importante reconhecer quem é o trabalhador que adoece e de que forma ele se insere no processo de produção.

Diante da experiência vivenciada, as gerentes de enfermagem projetam suas ações no futuro, revelando suas expectativas, as quais relacionam-se à redução da carga de trabalho, viabilizando mais tempo em suas vidas para a prática de atividades que lhes tragam prazer e tranquilidade além da possibilidade de se engajarem em projetos de pesquisa e na atividade docente, colaborando com a formação profissional e o avanço da enfermagem brasileira.

Para algumas gerentes, o projeto de vida futuro se remete à aposentadoria, uma vez que se reconhecem sujeitos atuantes e com uma história longa de engajamento e contribuição à profissão e à população. Desse modo, esperam poder desfrutar os anos restantes junto à família, com os amigos, desempenhando atividades produtivas que à ressiginifiquem socialmente e as façam tão felizes quanto foram durante a carreira profissional.

Considero importante ressaltar ainda que, a realização desta pesquisa sinaliza questões para a nossa prática profissional, enquanto enfermeiras, docentes e pesquisadoras. Apresento, a seguir um diagrama com as implicações para a prática que se evidenciam por meio da compreensão da incapacidade da força de trabalho sob a ótica de gerentes de enfermagem: 


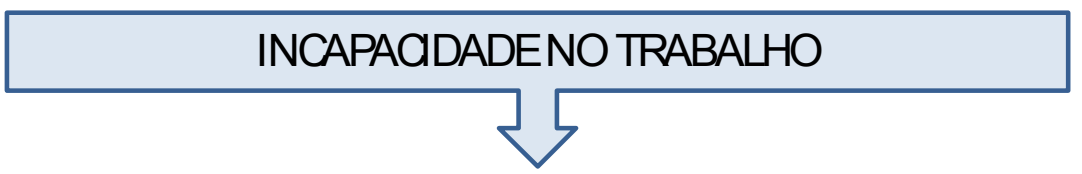

GERNTESDEENFEMAGEM

Políticas de recursos

humanos em saúde

- Reposição de pessoal
- Dimensionamento
quantitativo e qualitativo
- Educação permanente
- Remuneração adequada

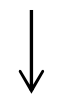

Políticas de saúde do trabalhador

- Vigilância à saúde do
trabalhador
- Monitoramento dos agravos
- Reabilitação precoce
- Programas de retorno ao
trabalho

- Instrumentalização para gestão participativa

- Oultura de segurança do paciente

- Oultura de valorização do potencial humano

\section{TRABALHADOR = PACENTE SEGURO $=$ SEGURO}

Ao desvelar o fenômeno a ação de gerenciar a força de trabalho em enfermagem incapacitada sob a ótica de gerentes de enfermagem, foi possível a reflexão não somente do contexto atual das incapacidades laborais nos trabalhadores de enfermagem, como do papel essencial do gerenciamento em enfermagem diante desta problemática.

Tenho a expectativa que os dados do presente estudo possam subsidiar novas pesquisas e sensibilizar outras esferas de poder para a reconstrução de uma politica séria de recursos humanos em saúde, com treinamento e reposição adequada de pessoal, somados à uma politica de vigilância à saude do trabalhador, fundamentais para o início de uma verdadeira transformação da força de trabalho em enfermagem. 
Referências 
Alves PC, Neves VF, Dela Coleta MF, Oliveira AF. Avaliação do bem-estar no trabalho entre profissionais de enfermagem de um hospital universitário. Rev. Lat Am Enfermagem. 2012;20(4):[08 telas]. Disponível em: http://www.scielo.br/pdf/rlae/v20n4/pt_10.pdf

André AM, Ciampone MHT, Santelle O. Tendências de gerenciamento de unidades de saúde e de pessoas. Rev Saúde Pública. 2013; 47(1): 158-163.

Baptista PCP, Merighi MAB, Silva A. Angústia de mulheres trabalhadoras de enfermagem que adoecem por distúrbios osteomusculares relacionados ao trabalho. Rev Bras Enferm. 2011;64(3): 438-44.

Baptista PCP. Avaliação das propostas de intervenção elaboradas a partir do Sistema de Monitoramento da Saúde dos Trabalhadores de Enfermagem (SIMOSTE) [relatório de pesquisa]. São Paulo: FAPESP; 2012.

Barros ARR, Griep RH, Rotenberg L. Automedicação entre os trabalhadores de enfermagem de hospitais públicos. Rev Lat Am Enfermagem. 2009;17(6): 1015-22.

Bartilotti CB, Andrade PR, Varandas JM, Ferreira PCG, Cabral C. Programa de Reabilitação Ampliada (PRA): uma abordagem multidimensional do processo de reabilitação profissional. Acta fisiátrica. 2009;16(2):66-75.

Batista JM, Juliani CMCM, Ayres JA. O processo de readaptação funcional e suas implicações no gerenciamento em enfermagem. Rev Lat Am Enfermagem. 2010;18(1):87-93.

$\square$ ellaguarda $\square \mathbf{L} \square, \quad \square$ adilha $\square \square, \square$ ereira $\square$ eto $\square \square$, $\square$ ires $\square$, $\square$ eres $\square \square \square$. $\square$ eflexão sobre a legitimidade da autonomia da enfermagem no campo das profiss $\square$ es de sa $\square$ de $\square$ luz das ideias de $\square$ liot $\square$ reidson. Rev Esc Anna Nery (impr.)2013; 17 (2):369 - 374

$\square$ endassoli $\square \square$. $\square$ econhecimento no trabalho $\square$ perspectivas e quest $\square$ es contempor $\square$ neas. $\square$ sicologia em $\square$ studo, $\square$ aring $\square . \square \square \square \square \square \square \square(\square \square \square \square-46$. 
Bernardino E. Mudança do modelo gerencial em um hospital de ensino: a reconstrução da prática de enfermagem. [tese] São Paulo: Escola de Enfermagem da Universidade de São Paulo; 2007.

Borges TP, Greve JMD, Monteiro AP, Silva RES da, Giovani AM, Silva MJP da. Aplicação da massagem para lombalgia ocupacional em funcionários de Enfermagem. Rev Lat Am Enfermagem.2012; 20(3): 511-519.

Brasil. Ministério da Previdência Social. Anuário Estatístico da Previdência Social. Brasília; 2010.

Brasil. Conselho Nacional de Secretários de Saúde. A Gestão do Trabalho e da Educação na Saúde. Brasília; 2011.

Brasil. Ministério da Saúde, Secretaria de Atenção à Saúde, Departamento de Brasil. Ministério da Saúde, Secretaria de Vigilância em Saúde, Departamento de Vigilância em Saúde Ambiental e Saúde do Trabalhador. Dor relacionada ao trabalho: lesões por esforços repetitivos (LER): distúrbios osteomusculares relacionados ao trabalho (Dort). Brasília; 2012.

Brasil. Ministério da Saude. Secretaria de Vigilância em Saude. Departamento de Analise de Situação em Saude. Saude Brasil 2012: uma analise da situação de saude e dos 40 anos do Programa Nacional de Imunizações. Brasília; 2013. p.327-344.

Brasil. Ministério da Saúde. Portaria GM n 529, de $1^{\circ}$ de abril de 2013. Institui o Programa Nacional de Segurança do Paciente (PNSP). In: Brasil. Ministério da Saúde. Programa Nacional de Segurança do Paciente. Brasília; 2013.

Campos GW de S. A mediação entre conhecimento e práticas sociais: a racionalidade da tecnologia leve, da práxis e da arte. Ciênc saúde coletiva 2011;16(7): 3033-3040.

Capalbo C. Metodologia das ciências sociais: a fenomenologia de Alfred Schütz. 2.ed.Paraná: UEL;1998. 97p. 
Carugno M, Pesatori AC Ferrario MM ; Ferrari AL, Silva FJ; Martins AC, et al. Physical and psychosocial risk factors for musculoskeletal disorders in Brazilian and Italian nurses. Cad Saúde Pública. 2012; 28(9): 1632-1642.

Castro FF. A sociologia fenomenológica de Alfred Schütz. Cienc soc Unisinos. 2012;48(1): 52-60.

Consonni D, Marinaccio A, Bertazzi PA, lavicoli S. Occupational health. Work related injuries decreasing, occupational diseases increasing. Epidemiol Prev. 2011; 35(5-6 Suppl 2): 106-7.

Chiodi MB, Marziale MHP, Robazzi MLCC. Occupational accidents involving biological material among public health workers. Rev Lat Am Enfermagem. 2007;15(4): 632-38.

Cockell FF, Perticarrari D. Retratos da informalidade: a fragilidade dos sistemas de proteção social em momentos de infortúnio. Cienc saude colet. 2011;16(3):1709-18.

Coggon D, Ntani G, Vargas-Prada S, Martinez JM, Serra C, Benavides FG et al. International variation in absence from work attributed to musculoskeletal illness: findings from the CUPID study. Occup Environ Med. 2013; 70(8): $575-584$.

Costa e Silva LIM da, Peduzzi M. Análise da produção científica sobre recursos humanos de enfermagem no Brasil. Acta Paul. Enferm. 2006;19(1): 36-42.

Dejours C. A Loucura do Trabalho - Estudo de Psicopatologia do Trabalho. 5.ed. São Paulo: Cortez; 2013. 127p.

Dias JRF, Araujo CS, Martins ERC, Francisco MTR, Sampaio $\square \square \square$. $\square$ atores predisponentes ao uso $\operatorname{pr}\lceil$ prio de psicotr $\square$ picos por profissionais de enfermagem. Rev enferm UERJ. 2011;19(3):445-51.

Diniz D, Squinca F, Medeiros M. Qual deficiência? Perícia médica e assistência social no Brasil. Cad Saúde Pública. 2007;23(11): 2589-96. 
Earle V. Phenomenology as research method or substantive metaphysics? $\square$ n overview of phenomenology's uses in nursing. Nursing Philosophy. 2010;11: 286-96.

Farias SMC, Teixeira OLC, Moreira W, Oliveira MAF, Pereira MO. Caracterização dos sintomas físicos de estresse na equipe de pronto atendimento. Rev Esc Enferm USP. 2011;45(3):722-29.

Felli VEA, Peduzzi M. A Saude do trabalhador e o gerenciamento em enfermagem. [Livre-docência]. São Paulo: Escola de Enfermagem, Universidade de São Paulo; 2002.

Felli VEA, Peduzzi M. O trabalho gerencial em enfermagem. In: Kurcgant $P$ (Coord). Gerenciamento em Enfermagem. Rio de Janeiro: Granabara Koogan; 2005. p 1-13.

Felli VEA, Baptista PCP. Avaliação e implementação do Sistema de Monitoramento da Saúde do Trabalhador de Enfermagem - SIMOSTE. Relatório de Pesquisa. São Paulo; 2010.

Fernandes MS, Spagnol CA, Trevizan MA, Hayashida M. a conduta gerencial da enfermeira: um estudo fundamentado nas teorias gerais da administração. $\square$ ev Lat $\square \mathrm{m} \square$ nfermagem. $\square \square \square \square \square \square(\square \square \| \square \square \square-7$.

Fernandes JC, Portela LF, Rotenberg L, Griep RH. Jornada de trabalho e comportamentos de saúde entre enfermeiros de hospitais públicos. Rev Lat Am Enfermagem. 2013; 21(5): 1104-11.

Ferraz CA, Gomes ELR, Mishima SM. O desafio teórico-prático da gestão dos serviços de saúde. Rev Bras Enferm. 2004; 57(4): 395-400.

Fonseca RP, Trentini CM, Valli F, Silva RAN. Representações do envelhecimento em agentes comunitários da saúde e profissionais da enfermagem comunitária: aspectos psicológicos do processo saúde-doença. Ciênc saúde coletiva. 2008;13( 4 ):1275-84. 
Gärtner FR, NieuwenhuijsenK, van Dijk FJH; Sluiter JK. Interpretability of change in the nurses work functioning questionnaire: minimal important change and smallest detectable change. J clin epidemiology. 2012;65(12):1337-47.

Giomo DB, Freitas FCT, Alves LA, Robazzi MAC. Acidentes de trabalho, riscos ocupacionais e absenteísmo entre trabalhadores de enfermagem hospitalar. Rev Enferm UERJ. 2009;17(1): 24-29.

Girardi SN, Carvalho CL. Configurações do mercado de trabalho dos assalariados em saúde no Brasil. Formação. 2002;2(6):15-35.

Girondi JBR, Gelbcke FL. Percepção do enfermeiro sobre os efeitos do trabalho noturno em sua vida. Enferm Foco. 2011;2(3):191-94.

Griep RH, Rotenberg L, Landsbergis P, Vasconcellos-Silva PR. Uso combinado de modelos de estresse no trabalho e a saúde auto-referida na enfermagem. Rev Saúde Pública. 2011;45(1):45-52.

Gupta R. The most effective short-term response to the crisis is to use existing resources better, and this means improving the management of health systems.In: Report on the first global forum on human resources or health; 2-7 march 2008. 21-29; Kampala,Uganda, 2008.

Gurgueira GP, Alexandre NMC. Laudos médicos recomendando restrições de trabalho em um hospital universitário no Brasil. Rev Lat Am Enfermagem. 2006;14(4): 510-16.

Hilleshein EF, Lautert L. Capacidade para o trabalho, características sociodemográficas e laborais de enfermeiros de um hospital universitário. Rev Lat Am Enfermagem. 2012;20(3):520-27.

IImarinen J, Tuomi K, Klockars M. Changes in the work ability of active employees over an 11-year period. Scand J Work Environ Health 1997;23suppl 1:49-57 
Jakobi HR, Barbosa-Branco A, Bueno LF, Ferreira RGM, Camargo LMA. Incapacidade para o trabalho: análise dos benefícios auxílio-doença concedidos no estado de Rondônia. Cienc saude colet. 2013;18(11): 3157-68.

Karino ME. As causas de morte dos enfermeiros: uma revisão sistemática [tese]. São Paulo: Escola de Enfermagem, Universidade de São Paulo; 2012.

Kawata LS, Mishima SM, Chirelli MQ, Pereira MJB. O trabalho cotidiano da enfermeira na saúde da família: utilização de ferramentas da gestão. Texto contexto enfermagem. 2009; 18( 2 ): 313-320.

Kessler Al, Krug SBF. Do prazer ao sofrimento no trabalho da enfermagem: o discurso dos trabalhadores. Rev Gaucha Enferm. 2012;33(1):49-55.

Kirchhof ALC, Magnago TSBS, Camponogara S, Griep RH, Tavares JP, Prestes FC et al. Condições de trabalho e características sócio-demográficas relacionadas à presença de distúrbios psíquicos menores em trabalhadores de enfermagem. Texto e contexto enferm. 2009;18(2):215-23.

Kurcgant $\mathrm{P}$, Tronchin DMR, Melleiro MM, Castilho V, Machado VB, Inahiá Pinhel I, et al. Indicadores de qualidade e a avaliação do gerenciamento de recursos humanos em saúde. Rev Esc Enferm USP.2009; 43(Esp 2):1168-73

Lahelma E, Laaksonen M, Lallukka T, Martikainen $P$, Pietiläinen $O$, Saastamoinen $\mathrm{P}$ et al. Working conditions as risk factors for disability retirement: a longitudinal register linkage study. BMC Public Health. 2012;12:309.

Lambeek LC, van Mechelen W, Buijs PC, Loisel P, Anema JR. An integrated care program to prevent work disability due to chronic low back pain: a process evaluation within a randomized controlled trial. BMC Musculoskeletal Disorders. 2009;10:147. 
LaMontagne AD, Keegel T, Vallance D, Ostry A, Wolf Rory. Job strain Attributable depression in a sample of working Australians: Assessing the contribution to health inequalities. BMC Public Health. 2008;8:181.

Leite PC, Merighi MAB, Silva A. A vivência de uma trabalhadora de enfermagem Portadora de lesão "de quervain". $\square$ ev Lat Am Enfermagem. $2007 ; 15(2)$.

Leite PC, Silva A, Merighi MAB. A mulher trabalhadora de enfermagem e os distúrbios osteomusculares relacionados ao trabalho. Rev Esc Enferm USP. 2007;41(2):287-91.

Leite PC. A vivência de mulheres trabalhadoras de enfermagem que apresentam distúrbios osteomusculares relacionados ao trabalho (DORT): uma abordagem compreensiva da fenomenologia existencial. [tese], São Paulo: Escola de Enfermagem, Universidade de São Paulo, 2006.

Lima AFC, Kurcgant $P$. Indicadores de qualidade no gerenciamento de recursos humanos em Enfermagem. Rev Bras Enf . 2009;62(2):234-9.

Loisel P, Durand MJ. Applying transdisciplinary to the complexity of work disability prevention. Centro de Educação Transdisciplinar CETRANS; 2005 [citado em 18 dez 2013]. Disponível em: http://cetrans.com.br/artigos/Patrick_Loisel.pdf

Loisel P, Lemaire J, Poitras S, Durand MJ, Champagne F, Stock S et al. Cost-benefit and cost-effectiveness analysis of a disability prevention model for pain management: a six year follow up study. Occup Environ Med. 2002;59:807-15.

Maeno M. Por que conversamos ainda sobre DORT? Sindicato dos Metalúrgicos de São Paulo e Mogi das Cruzes. 2011 mar. 16 [citado 2013 dez. 5].

Disponível em: http://www.metalurgicos.org.br/materia.asp?id_CON=3208 
Martins AC. Sintomas osteomusculares relacionados ao trabalho de enfermagem em Unidade de Terapia Intensiva [dissertação]. São Paulo: Escola de Enfermagem, Universidade de São Paulo; 2011.

Melo LEA. A Previdência Social e a Luta Contra os Acidentes e Doenças do Trabalho no Brasil. Resultado do RGPS de Junho de 2011. Informe de Previdência Social. 2011;23(7). [citado 2013 dez. 17]. Disponível em: http://www.previdencia.gov.br/arquivos/office/3_110728-104424-440.pdf

Merighi MAB, Praça NS. Abordagens teórico-metodológicas qualitativas. A vivência da mulher no período reprodutivo. Rio de Janeiro: Guanabara Koogan; 2003.

Mininel VA, Baptista PCP, Felli VEA. Cargas psíquicas e Processos de desgaste em Trabalhadores de enfermagem de hospitais Universitários Brasileiros. Rev Lat Am Enfermagem. 2011;19(2):340-347.

Mininel VA, Felli VEA, Silva EJ, Torri Z, Abreu AP, Branco MTA. Cargas de trabalho, processos de desgaste e absenteísmo-doença em enfermagem. Rev Lat Am Enfermagem. 2013;21(6):1290-97. DOI: 10.1590/01041169.2992.2366

Mininel VA. Adaptação transcultural do Work Disability Diagnosis Interview (WoDDI) para o contexto brasileiro [tese]. São Paulo: Escola de Enfermagem, Universidade de São Paulo; 2010.

Mininel VA, Felli VEA, Loisel P, Marziale MHP. Adaptação transcultural do Work Disability Diagnosis Interview (WoDDI) para o contexto brasileiro. Rev. latino-am. enfermagem. 2012;20(1):27-34.

Monk TH; Buysse DJ; Billy BD; Fletcher ME; Kennedy KS; Begley AE; Schlarb JE; Beach SR Shiftworkers report worse sleep than day workers, even in retirement. J Sleep Res; 22(2): 201-8, 2013 Apr. 
Mueller M, Lohmann S, Strobl R, Boldt C, Grill E. Patients' functioning as predictor of nursing workload in acute hospital units providing rehabilitation care: a multi-centre cohort study. BMC Health Serv Res. 2010;10:295.

$\square$ livar $\square \mathrm{S} \square . \square$ campo poltico da sa $\square$ de do trabalhador e o Serviço Social.Serv Soc Soc. 2010. 102: 314-338.

Oliveira AF, Teixeira ER, Silvino ZR, Christovam $\square \square$, $\square$ utomedicação entre os trabalhadores da sa $\square$ de $\square$ revisão integrativa. $\square$ ev enferm 7(esp):6254-61.

Pereira MJB, Fortuna CM, Mishima SM, Almeida MCP de, Matumoto S. A enfermagem no Brasil no contexto da força de trabalho em saúde: perfil e legislação. Rev Bras Enferm. 2009; 62( 5 ): 771-777.

Pierantoni CR, Varella TC, Santos M R dos, França T, Garcia AC. Gestão do trabalho e da educação em saúde: recursos humanos em duas décadas do SUS. Physis. 2008; 18 ( 4 ): 685-704.

Pinheiro J, Zeitoune $\square \square \mathrm{G}$. $\square$ profissional de enfermagem e a realização do teste sorol $\square$ gico para hepatite $\square$. $\square$ ev $\square$ nferm $\square \square \square \square . \square \square \square \square \square \square(\square \| \square \square-4$.

Pires AS, Ribeiro LV, Souza NVDO, Gonçalves FGA, Costa CCP. A subjetividade no mundo do trabalho sob a ótica do trabalhador de enfermagem com possibilidade de aposentadoria. Rev Pesqu Cuid fundam. (Online).2013; 5(2)abr.-jun.

Pransky G, Shaw WS, Loisel P, Hong QN, Désorcy B. Development and Validation of Competencies for Return to Work Coordinators. Journal of Occupational Rehabilitation. 2010;20(1):41-48.

Ratier APP. Qualidade de vida de trabalhadores de Enfermagem com Distúrbios Osteomusculares Relacionados ao Trabalho [dissertação]. São Paulo: Escola de Enfermagem, Universidade de São Paulo; 2012. 
Reinhardt EL, Fischer FM. Barreiras às intervenções relacionadas à saúde do trabalhador do setor saúde no Brasil. Rev Panam Salud Publica. 2009; 25(5):411-17.

Rodrigues CP, Oliveira N FS, Vieira TAA, Brasileiro ME. O sofrimento dos trabalhadores informais, vítimas de acidente de trabalho. Revista Eletrônica de Enfermagem do Centro de Estudos de Enfermagem e Nutrição. 2012;1(1):1-13.

Rogenski KE, Fugulin FMT, Gaidzinski RR, Rogenski NMB. Tempo de assistência de enfermagem em instituição hospitalar de ensino. Rev Esc Enferm USP. 2011;45(1):223-29.

Sancinetti TR, Gaidzinski RR, Felli VEA, Fugulin FMT, Baptista PCP, Ciampone MHT et al. Absenteísmo - doença na equipe de enfermagem: relação com a taxa de ocupação. Rev Esc Enferm USP. 2009; 43(spe2): 1277-83.

Santana LL, Miranda FMD, Karino ME, Baptista PCP, Felli VEA, Sarquis LMM. Cargas e desgastes de trabalho vivenciados entre trabalhadores de saúde em um hospital de ensino. Rev Gauch Enferm. 2013;34(1):64-70.

Scalco SV, Lacerda JT de, Calvo MCM.. Modelo para avaliação da gestão de recursos humanos em saúde. Cad. Saúde Pública. 2010; 26(3): 603-614.

Schmidt DRC, Dantas RAS, Marziale MHP. Ansiedade e depressão entre profissionais de enfermagem que atuam em blocos cirúrgicos. Rev Esc Enferm USP. 2011;45(2):487-93

Schütz A, Luckmann T. Las estructuras del mundo de la vida. Buenos Aires: Amorrortu; 2009

Schütz A. El problema de la realidade social. Buenos Aires: Amorrortu; 2008.

Silva FJ. A capacidade para o trabalho e a fadiga entre trabalhadores de enfermagem [dissertação]. São Paulo: Escola de Enfermagem, Universidade de São Paulo; 2011. 
Silva SM, Baptista PCP. Novos olhares sobre o sujeito que adoece no trabalho hospitalar. Cogitare Enferm. 2013;18(1):163-66.

Silva SM. Retorno ao trabalho: a vivência dos trabalhadores de enfermagem com Distúrbios Osteomusculares Relacionados ao Trabalho (DORT) [dissertação]. São Paulo: Escola de Enfermagem, Universidade de São Paulo; 2012.

Souza MNC. Algumas considerações sobre a sociologia de Alfred Schütz. Em tese. 2012;9(1):1-26.

Souza NSS, Santana VS. Fatores associados à duração dos benefícios por incapacidade: um estudo de coorte. Rev Saúde Publica. 2012;46(3):425-34.

Stansfeld S, Candy B. Psychosocial work environment and mental health - a meta-analytic review. Scand J Work Environ Health. 2006;32(6):443-62.

Takahashi MAB, Simonelli AP, Sousa HP, Mendes RWB, Alvarenga MVA. Programa de reabilitação profissional para trabalhadores com incapacidades por LER/DORT: relato de experiência do Cerest-Piracicaba, SP. Rev bras saude ocup. 2010;35(121):100-11.

Tito RS. Burnout e Transtornos Mentais comuns nos trabalhadores de enfermagem que assistem crianças com cardiopatia grave [dissertação]. São Paulo: Escola de Enfermagem, Universidade de São Paulo; 2013.

Toldrá RC, Daldon MTB, Santos MC, Lancman S. Facilitadores e barreiras para o retorno ao trabalho: a experiência de trabalhadores atendidos em um Centro de Referência em Saúde do Trabalhador - SP, Brasil. Rev Bras Saúde Ocup. 2010;35(121):10-22.

Tuomi K, Ilmarinem J, Jahkola A, Katajarinne L, Tulkki A. Índice de capacidade para o trabalho. Trad. de Frida Marina Fisher (Coord). Sao Carlos: EDUFSCAR, 2005. P.7-52.

Tuomi K, Huuhtanem P, Nykyri E, Ilmarinem J.Promotion of work ability, the quality ofwork and retirement. Occup Med. 2001; 51(5): 318-324. 
Umann J, Guido LA, Grazziano ES. Presenteísmo em enfermeiros hospitalares. Rev Lat Am Enfermagem. 2012;20(1):159-66.

Vieira TG, Beck, Dissen et al. Adoecimento e uso de medicamentos psicoativos entre trabalhadores de enfermagem de unidades de terapia intensiva. Rev Enferm UFSM. 2013;3(2):205-214.

Vieira M, Chinelli F. Relação contemporânea entre trabalho, qualificação e reconhecimento: repercussões sobre os trabalhadores técnicos do SUS. Cienc. saude colet. 2013;18(6):1591-1600.

Wagner HR, organizador. Sobre fenomenologia e relações sociais. Rio de Janeiro: Vozes; 2012.

Watcher R M. Compreendendo a segurança do paciente. Porto Alegre: Artmed, 2010.

Zeferino MT, Carraro TE. Alfred Schütz: do referencial teórico-filosófico aos princípios metodológicos de pesquisa fenomenológica. Texto \& contexto enferm. 2013;22(3):826-34.

$\square$ nidar $\square \square \square$. $\square$ ontinuous $\square$ ducation $\square$ f $\square$ Ider $\square$ mployees $\square \square$ ost $\square$ r $\square$ enefit $\square$ International Business \& Economics Research Journal. 2012; 11(8): 911-920. 
Apêndice 
Apêndice 1. Termo de Consentimento Livre e Esclarecido para as entrevistas

$\mathrm{Eu}$ inserido no serviço/instituição

concordo em participar da pesquisa intitulada "Incapacidade no trabalho: a compreensão de gerentes de enfermagem", que tem como objetivo compreender o processo de adoecimento e incapacidade no trabalho sob o enfoque gerencial. Sou convidado a participar de entrevista individual e autorizo a gravação da entrevista e a divulgação científica das informações fornecidas.

Fui orientado sobre o caráter científico da investigação, na qual a minha colaboração é estritamente voluntária, sendo-me assegurado retirar este consentimento em qualquer fase da pesquisa, sem nenhuma penalização ou prejuízo à minha pessoa e à instituição de ensino na qual estou inserido. Também foi assegurado que não haverá identificação pessoal e que as informações fornecidas serão confidenciais. Este 'Termo de consentimento livre e esclarecido' é assinado em 2 (duas) vias, uma via permanece comigo, pois concordei em participar da pesquisa, e outra com o pesquisador.

Assinatura de consentimento do participante da pesquisa

Assinatura do pesquisador responsável pela investigação

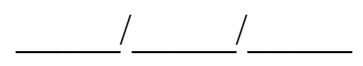

Patrícia Campos Pavan Baptista

Escola de Enfermagem da Universidade de São Paulo (EEUSP)

Departamento de Orientação Profissional.

Av. Dr. Enéas de Carvalho Aguiar, 419. Cerqueira Cesar.

CEP: 05403-000. São Paulo-SP.

Telefone: (11) 3066-7552.e-mail: pavanpati@usp.br 
